\title{
Bioactive Properties of Marine Phenolics
}

\author{
Raquel Mateos ${ }^{1}$, José Ricardo Pérez-Correa ${ }^{2} \mathbb{D}$ and Herminia Domínguez ${ }^{3, *}$ \\ 1 Institute of Food Science, Technology and Nutrition (ICTAN-CSIC), \\ Spanish National Research Council (CSIC), José Antonio Nováis 10, 28040 Madrid, Spain; \\ raquel.mateos@ictan.csic.es \\ 2 Department of Chemical and Bioprocess Engineering, Pontificia Universidad Católica de Chile, Macul, \\ Santiago 7810000, Chile; perez@ing.puc.cl \\ 3 CINBIO, Department of Chemical Engineering, Faculty of Sciences, Campus Ourense, Universidade de Vigo, \\ As Lagoas, 32004 Ourense, Spain \\ * Correspondence: herminia@uvigo.es; Tel.: +34-988-387082
}

Received: 7 August 2020; Accepted: 25 September 2020; Published: 30 September 2020

check for updates

\begin{abstract}
Phenolic compounds from marine organisms are far less studied than those from terrestrial sources since their structural diversity and variability require powerful analytical tools. However, both their biological relevance and potential properties make them an attractive group deserving increasing scientific interest. The use of efficient extraction and, in some cases, purification techniques can provide novel bioactives useful for food, nutraceutical, cosmeceutical and pharmaceutical applications. The bioactivity of marine phenolics is the consequence of their enzyme inhibitory effect and antimicrobial, antiviral, anticancer, antidiabetic, antioxidant, or anti-inflammatory activities. This review presents a survey of the major types of phenolic compounds found in marine sources, as well as their reputed effect in relation to the occurrence of dietary and lifestyle-related diseases, notably type 2 diabetes mellitus, obesity, metabolic syndrome, cancer and Alzheimer's disease. In addition, the influence of marine phenolics on gut microbiota and other pathologies is also addressed.
\end{abstract}

Keywords: bromophenols; simple phenolics; flavonoids; phlorotannins; seawater; algae; seagrass; health benefits; biological activity

\section{Introduction}

The occurrence of dietary and lifestyle-related diseases (type 2 diabetes mellitus, obesity, metabolic syndrome, cancer or neurodegenerative diseases) has become a health pandemic in developed countries. Global epidemiological studies have shown that countries where seaweeds are consumed on a regular basis have significantly fewer instances of obesity and dietary-related diseases [1]. Among marine metabolites with biological properties, phenolic compounds have attracted great interest. However, compared to those found in terrestrial sources, their study is recent and challenging in different aspects. Some families of phenolic compounds have been reported in both terrestrial and marine organisms but others, such as bromophenols and phlorotannins, are exclusively found in marine sources. The natural production of phenolic compounds in marine organisms has been associated with external factors, particularly with environmental stressing conditions, such as desiccation, salinity, UV radiation, nutrients availability, and temperature [2-5]. Variability and dependence with species, seasonality and environmental conditions occur for macroalgae [6-8] and seagrass [9-11] and with the growing conditions on microalgae [12].

Different extraction strategies have been successfully used, from conventional solvent extraction with water or with organic solvents to alternative techniques using either greener solvents or intensification tools to enhance yields and rates [13]. Enzymatic-assisted hydrolysis provided 
higher extraction rate and extraction yields, with lower time and cost, but appeared less effective for polyphenols because the extraction of other fractions such as proteins and saccharides was enhanced [14,15]. Ultrasonication aided in the disruption of marine algal biomass and the enhanced extraction of components [3,16-18]; hence, it can also be applied as a pretreatment [17]. However, degradation of bioactives could occur due to sonication induced effects such as high temperatures and radical's generation. Cleaner and efficient polyphenol extraction processes using safer solvents are increasingly demanded. Supercritical $\mathrm{CO}_{2}$ extraction complies with these requirements and offers advantages derived from the tunablity of the solvation power by modifying pressure and temperature; however, due to its apolar character it requires the addition of polar modifiers. Most studies have been reported with crude solvent extracts; therefore, the properties cannot be ascribed to a single compound, and the synergistic effects among the components should be considered. Depending on the final use, a series of fractionation stages, would be required, because more active fractions can be obtained by purification of crude extracts $[19,20]$.

The most basic phenolics quantification relies on the colorimetric Folin-Ciocalteu assay, but modern analytical tools have contributed to the provision of information on the complex structure of marine phenolics [21,22], usually with chromatographic, IR spectroscopic and NMR methods [9,10,23,24]. Advanced and coupled techniques such as HPLC-DAD-ESI/MS and UPLC-ESI-QTOF/MS analyses [5,7,20,25,26], LC-ESI-MS/MS [27], RRLC-ESI-MS [28], UPLC [29], UPLC-MS [25], UPLC-MS/MS TIC [4], ${ }^{1} \mathrm{D}$ and ${ }^{2} \mathrm{D}$ NMR techniques $\left({ }^{13} \mathrm{C}-\mathrm{NMR}, \mathrm{COSY}\right.$, TOCSY, NOESY, HSQC) [24], are required to unveil the highly diverse and complex chemical structure of marine phenolics. The development of strategies for simultaneous determination and quantification of the different phenolic subclasses is needed [20]. Particularly interesting has been the identification of phlorotannins, which show an extremely large diversity and complexity, regarding the number or monomeric basic units, distribution of hydroxyl groups and structural conformations of isomers $[7,25,29]$. In addition, their combination with preconcentration, and hydrolysis allowed simultaneous determination of phenolics in minutes [28]. Biological resources including seaweed may contain toxic compounds, such as heavy metals, and the evaluation of toxicity is required prior to focusing on any other activity $[30,31]$.

Abundant reviews of the bioactive properties of marine phenolics can be found [32-36]. Most of them have been focused on seaweeds, but other marine organisms deserve interest as potential worldwide distributed and ubiquitous sources of phenolic compounds. Furthermore, the extensive variety of biological activities with potential to improve human and animal health, as well as the possibility of using these compounds for the formulation of novel products, configurates the food and feed applications as an efficient route of administration to maintain health and for preventing and treating different diseases. This review presents an overview of the major phenolic compounds found in marine sources and discusses their relevant biological properties in relation to lifestyle related diseases.

\section{Marine Phenolics: Sources and Phenolic Composition}

\subsection{Families of Phenolic Compounds Identified in Marine Sources}

Marine organisms are a rich source of phenolics that include bromophenolic compounds, simple phenolic acids and flavonoids as well as phlorotannins. Figure 1 shows the basic structure of some key classes of the marine phenolics identified. Examples of each class were selected based on their biological relevance in the reported studies. 

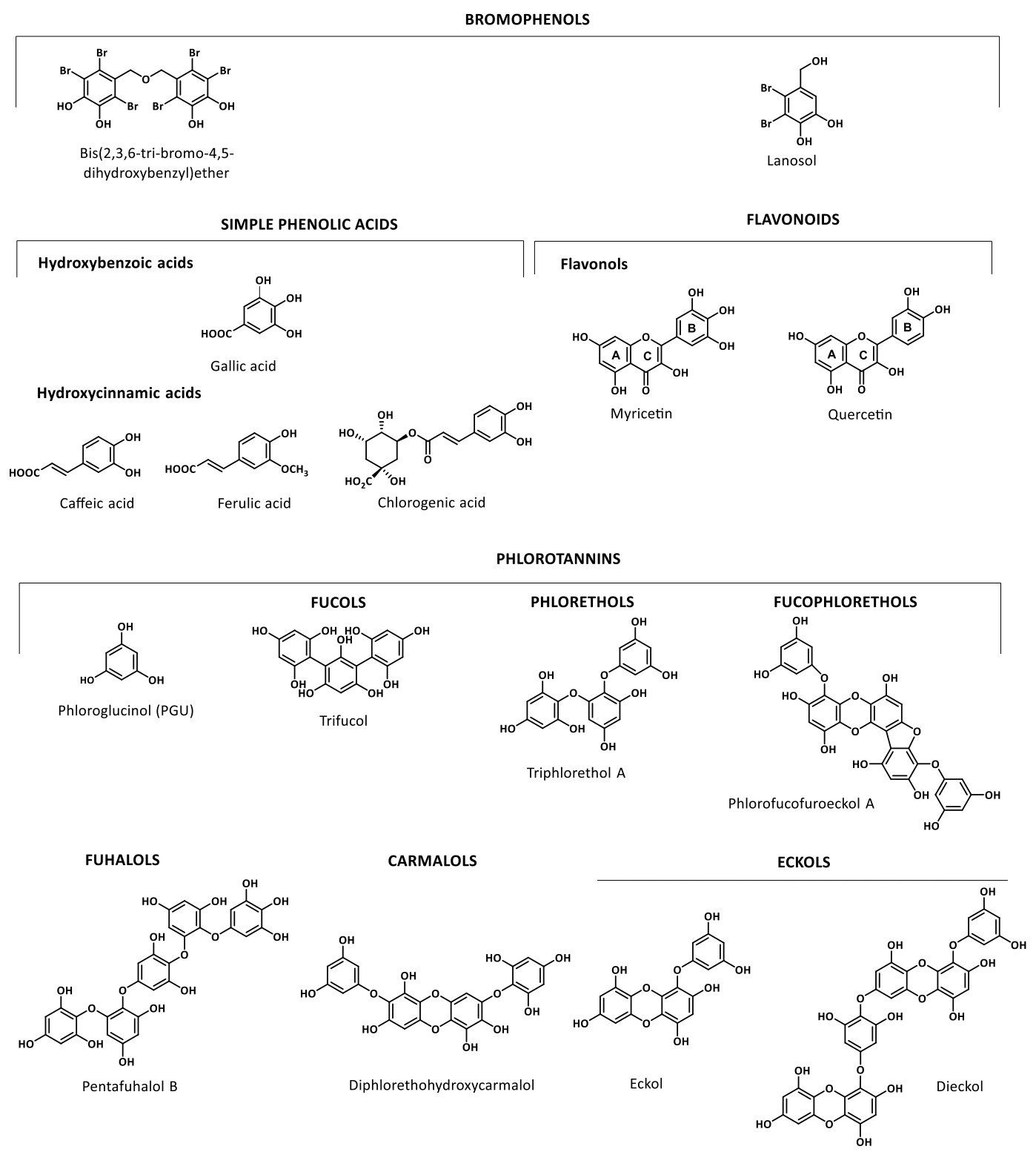

Figure 1. Examples of the families of phenolic compounds found in marine sources: bromophenols, simple phenolic acids and flavonoids, different types of phlorotannins (fucols, phlorethols, fucophlorethols, fuhalols, carmalols and eckols, as well as phloroglucinol monomeric unit).

Bromophenolic compounds have been found in several macroalgae (red, green and brown) and cyanobacteria. They can be transferred through the food chain from macroalgae to invertebrate grazers to fish. Since some of them have toxic properties similar to those of anthropogenic contaminants, their characterization is needed [37]. The lack of reports regarding the industrial production of commercially available bromophenols (hydroxylated and methoxylated bromodiphenyl ethers) suggest that they should come from natural sources and from biotransformation of natural and anthropogenic compounds [38]. Red algae are the major source of natural marine bromophenols [39], but other organisms such as fish, shrimps and crabs ingest them through the food chain. Cade et al. [38] found polybrominated diphenyl ethers (PBDEs) at higher concentration in finfish than in shellfish. Among shellfish, bivalves (clams and mussels) tended to have higher levels of hydroxylated and methoxylated PBDEs than other types of seafood. Koch and Sures [40] have compiled information on the concentrations of tribromophenols in aquatic organisms, ranging from 7 to $1600 \mathrm{ng} / \mathrm{g}$ algal ww, 0.3 to $2360 \mathrm{ng} / \mathrm{g}$ crustacean ww, 0.9 to $198 \mathrm{ng} / \mathrm{g}$ mollusks dw, 3.7 to $230 \mathrm{ng} / \mathrm{g}$ fish ww. 
Phenolic acids and flavonoids have also been found in marine sources. Among phenolic acids, there are two major groups, hydroxycinnamic acids and hydroxybenzoic acids, whereas flavonols, belonging to flavonoids is the most abundant group of compounds identified in marine organisms [20,41,42]. Phlorotannins, exclusively found in brown seaweeds, are complex polymers of phloroglucinol (1,3,5-trihydroxybenzene). This structurally heterogeneous group presents a complex chemical composition, diverse linkage positions and a degree of polymerization (126 Da-650 kDa) [21] which determine its biological properties. The structural classification is based on the inter-monomeric linkages: fucols possess only aryl-aryl linkages, phlorethols aryl-ether linkages, fuhalols possess only ether linkages and additional $\mathrm{OH}$ groups in every third ring, fucophlorethols possess aryl-aryl and aryl-ether units, carmalols are derived from phlorethols and possess a dibenzodioxin moiety, and eckols that possess at least one three-ring moiety with a dibenzodioxin moiety substituted by a phenoxyl group at C-4 [43-45].

\subsection{Sources}

\subsubsection{Seawater}

The most abundant phenolic compounds found in seawater are sinapic acid, catechin, myricetin, kaempherol and protocatechuic acid (found at $0.8-2.8 \mathrm{nM} / \mathrm{L}$ ), whereas vanillic acid, coumaric acid, ferulic acid, and rutin are below $0.5 \mathrm{nM} / \mathrm{L}$ [46]. In a recent study on the presence of free phenolic compounds in Antarctic sea water, Zangrando et al. [42] concluded that the release from phytoplankton could be the origin of phenolics in seawater, since diatoms produce exudates that contain phenolic compounds. Other possible but less plausible sources could be the intrusion of circumpolar deep water that may transport oceanic lignin; the melting of glaciers, which contain lignin that can be degraded in the snow; photooxidation in water; the photochemical and microbiological degradation of lignin contained in dissolved organic material. These authors have found vanillin, vanillic acid, acetovanillone and p-coumaric acid, both in the dissolved and particulate fractions in seawater samples, with syringic acid, syringaldehyde and homovanillic acid at residual concentrations. Bidleman et al. [37] also reported the presence of the bromophenol lanosol (2,3-dibromo-4,5-dihydroxybenzyl alcohol) in seawater.

\subsubsection{Microalgae}

Microalgae conform a highly ecologically diverse group of unicellular eukaryotic organisms; they are the most important primary source of biomass in aquatic ecosystems. They are able to produce a wide variety of commercially interesting compounds, such as lipids, carbohydrates, phenolics, carotenoids, sterols, vitamins, and other bioactives [47]. Microalgae offer advantages over terrestrial sources derived from their metabolic diversity and adaptive flexibility, the efficient photosynthesis and high growth rate, the possibility of large scale cultivation, simple nutritional requirements, and their ability to accumulate or secrete metabolites [48]. Microalgae can grow in different habitats such as fresh water, saltwater and marine environments. They can even grow on industrial wastewaters [49]. The valuable bioactives with pharmaceutical, food, feed, and cosmetic applications $[50,51]$ from microalgae could be relevant regarding the higher profitability of the cultivation processes and could complement the energetic application [47]. In fact, the extraction of phenolic compounds from microalgae biomass does not interfere with already established processes such as biofuel production [27].

Microalgae produce protective antioxidant compounds in response to stress damage caused by UV radiation, temperature variation, excessive light, and others. In some cases, these are not influencing factors. Gómez et al. [52] observed that the accumulation of phenolic compounds in some microalgae was independent of the illumination condition. The production of flavonoids and polyphenols could be favored with the adequate control of selected variables of the culture process [12]. Non-natural factors, such as $\mathrm{CuO}$ nanoparticles, can induce the production of phenolics in Nannochloropsis oculata [53], lowering growth rates as well as chlorophyll and carotenoids content. Moreover, $\mathrm{CuO}$ nanoparticles 
damaged the membrane as well as increased the activity of antioxidant endogenous enzymes, such as catalase, ascorbate peroxidase, polyphenol oxidase and lactate dehydrogenase.

Some phenolics in marine microorganisms are released into the environment to form metal complexes in order to acquire micronutrients or to sequester toxic metals, and their presence can stimulate the growth of diatoms. Catechin, sinapic acid, apigenin, quercitrin, kaempferol, epicatechin, gentisic acid, syringic acid, chlorogenic acid, vanillic acid, ferulic acid, caffeic acid, protocatechuic acid, coumaric acid, rutin and gallic acid have been reported in the exudates from diatoms $[42,54,55]$.

Data in Tables 1-3 summarize the phenolic compounds reported in marine organisms and their in vitro antioxidant characteristics, which could be used as a preliminary indication of potential bioactivities. Phenolic compounds can be efficient antioxidants acting with different mechanisms, as scavengers of singlet oxygen and free radicals, reducing agents, chelating agents, inhibiting specific oxidative enzymes or can act by mixed mechanisms. Assays to determine the reducing and antiradical properties against 2,2-diphenyl-1-picrylhydracil (DPPH), as well as 2,2'-azino-bis (3-ethylbenzothiazoline-6-sulphonic acid) (ABTS), superoxide and hydroxyl radicals, are usually preferred to screen the most active extracts from natural sources. Data in Table 1 confirm that phenolic acids, and particularly hydroxycinnamic acids, are the major families identified in microalgae.

Considering the diversity of phenolic compounds found in marine organisms, and the influence of composition on the activity, the selection of the extraction solvent is important and should be chosen with care, either individually or in mixtures [3,17]. Some examples are cited to illustrate this fact. In a comparative study, acetone provided the highest phenolic content in extracts from Isochrysis galbana, Tetraselmis sp. and Scenedesmus sp. The highest radical scavenging activity was observed in the acetone extract of I. galbana, the maximum Fe (II) chelating capacity in the hexane extract of Scenedesmus sp. and the in vitro inhibition of acetylcholinesterase in the water and ether extracts of both microalgae. Whereas the antiradical properties of the polar extracts can be ascribed to phenolics, in the non-polar extracts the activity could be due to fatty acids or to other lipophilic components [56]. Aqueous and methanolic extracts provided higher phenolic yield and reducing power from Nannochloropsis gaditana than acetone, dichloromethane or hexane; however, acetone provided the highest DPPH radical scavenging activity and cytotoxicity against human lung cancer cells (A549) [57]. Moreover, the methanolic extracts of Chaetoceros curvisetus, Thalassiosira subtilis and Odontella aurita were more active than those in acetone and in hexane [58].

In some cases, a linear relationship between phenolic content and antioxidant and biological properties has been established. Phenolic content is correlated with DPPH radical scavenging activity [18,59] and also with antitumoral properties [56]. Solvent extracts from Nannochloropsis oceanica showed reducing and antiradical properties and those from Skeletonema costatum and Chroococcus turgidus showed chelating ability; both properties are correlated with the phenolic content [59]. However, this correlation was found to be insignificant in other extracts, suggesting that these might not be major contributors to the antioxidant capacities [60]. Safafar et al. [49] reported that phenolic compounds were the major contributors to the antioxidant activity in microalgal extracts, but also carotenoids contributed to the DPPH radical scavenging activity, ferrous reduction power (FRAP), and ABTS-radical scavenging capacity activity. Maadame et al. [3] did not find correlation between the antioxidant capacities and the phenolic and carotenoids content in ethanolic extracts [57]. The low phenolic content (0.3-20 mg GAE/g DW) in microalgal extracts $[48,56,58]$ could suggest that other compounds could be responsible for the observed activities, such as carotenoids, fatty acids, sterols, vitamins as well as other compounds such as micosporine-like aminoacids (MAAs) [61]. The TEAC (Trolox equivalent antioxidant capacity) values and antiproliferative activities of phytoplankton extracts show a strong positive correlation with the amount of the total carotenoids and micosporine-like aminoacids, but were negatively correlated with the amounts of phenolic compounds [18]. 
Table 1. Phenolic compounds identified in different marine organisms: microalgae, cyanobacteria, fungus, seagrasses and sponges.

\begin{tabular}{|c|c|c|}
\hline $\begin{array}{l}\text { Marine Organism } \\
\text { Extraction } \\
\text { Chemical Analysis }\end{array}$ & $\begin{array}{l}\text { Phenolic Compounds } \\
\text { Antioxidant Activity (When Provided) }\end{array}$ & Ref. \\
\hline \multicolumn{3}{|c|}{ Marine-derived Fungus } \\
\hline $\begin{array}{l}\text { Alternaria sp. SCSIO41014 from sponge } \\
\text { AC, EtOAc, US } \\
\text { HPLC-UV, HRESIMS, NMR, ECD, XRay }\end{array}$ & Perylenequinone derivatives; altenusin derivative; phenol derivatives & [62] \\
\hline $\begin{array}{l}\text { Arthrinium sp. } \\
\text { MeOH, MeCN } \\
\text { HPLC, HRESIMS, NMR }\end{array}$ & 2-(2,3-Dihydroxy-5-methyl benzoyl)-6-hydroxybenzoic acid & [63] \\
\hline $\begin{array}{l}\text { Aspergillus sydowii, from the sponge Stelletta sp. } \\
\text { EtOAc, BuOH } \\
\text { HPLC, UV, IR, HRESIMS, NMR, OP }\end{array}$ & $\begin{array}{l}\text { Diorcinolic acid; } \beta \text {-D-glucopyranosyl aspergillusene A; diphenylethers; chromone; xanthone } \\
\text { first glycoside of phenolic bisabolane sesquiterpenes }\end{array}$ & [64] \\
\hline $\begin{array}{c}\text { Aspergillus sp. from the sponge Xestospongia testudinaria } \\
\text { EtOAc, AC } \\
\text { RP-HPLC, HRESIMS, NMR }\end{array}$ & Phenolic bisabolane sesquiterpenoid dimers (disydonols A-C), (S)-(+)-sydonol & [65] \\
\hline $\begin{array}{c}\text { Aspergillus sp. from the sponge Chondrilla nucula } \\
\text { EtOAc } \\
\text { HPLC-PDA, UV, HRESIMS, NMR, OP }\end{array}$ & Phenolic bisabolane sesquiterpenes; asperchondol A; asperchondol B & [66] \\
\hline $\begin{array}{l}\text { Aspergillus sp., from the sponge Chondrilla nucula } \\
\text { EtOAc, BuOH } \\
\text { HPLC, UV, IR, HRESIMS, NMR, OP }\end{array}$ & Phenolic bisabolane sesquiterpenes; asperchondols A and B; diphenyl ethers & [64] \\
\hline $\begin{array}{l}\text { Aspergillus versicolor, deep-sea fungus } \\
\text { EtOAc, BuOH } \\
\text { HPLC, IR, TLC, HRESIMS, NMR, OP, ECD }\end{array}$ & $\begin{array}{l}\text { Aspergilols A-F; diorcinal; cordyol E; 4-carboxydiorcinal; 4-methoxycarbonyldiorcinol; 4-carbethoxydiorcinal; } \\
\text { cordyol C; methylgerfelin; violaceol II; averythrin; averantin, 1'-O-methylaverantin; lecanoric acid; orsellic acid; } \\
\text { orcinol; 1- methylpyrogallol; fumaric acid } \\
\text { ABTS }=0.1-5.4 \text { mmol Trolox/g }\end{array}$ & [67] \\
\hline $\begin{array}{c}\text { Cladosporium cladosporioides from Sargassum wightii } \\
\text { EtOAc } \\
\text { LC-MS }\end{array}$ & $\begin{array}{c}\text { N-(2-Iodophenyl)-2-[2-oxo-5-(thiophen-2-yl)-2,3-dihydro-1,3,4-oxadiazol-3-yl] acetamide; } \\
\text { 2-[3-chloro-4-(4-chlorophenoxy)phenyl]-1,3-dioxo-2,3-dihydro-1H-isoindole-5-carboxylic acid; } \\
\text { 2-(2,4-dichlorophenyl)-2-oxoethyl 3,4-dihydro-2H-1,5-benzodioxepine-7-carboxylate; } \\
\text { 4-bromo-N'-(4-fluoro-1-benzothiophene-2-carbonyl)-1H-pyrrole-2-carbohydrazide; } \\
\text { (1R,2R,5S)-2-[3-(\{2-[(2,4-dichlorophenyl)methyl]-2H-1,2,3,4-tetrazol-5-yl\}methyl)-4-methyl-5 } \\
\text { sulfanylidene-4,5-dihydro-1H-1,2,4-triazol-1-yl]-6,8-dioxabicyclo [3.2.1]octan-4-one; methyl 2-(\{[5-bromo-2-(4 } \\
\text { methoxybenzamido)phenyl] (phenyl)methyl\}amino) acetate; } \\
\text { 2-[4-(2,4-dichlorophenoxy)phenyl]-5-phenyl-octahydro-1H-isoindole-1,3-dione; N-(\{2-[(3,4-dichlorophenyl) } \\
\text { methoxy]naphthalen-1-yl]methyl)-2,3-dihydro-1,4-benzodioxin- 6-amine; 2-(\{[(2,4-dichlorophenyl) carbamoyl] } \\
\text { methyl\}(propyl)amino)-N-(2,2,2-trifluoroethyl) acetamide; } \\
\text { N-(4-bromo-2-fluorophenyl)-6-(2-tert-butylhydrazin1-yl)-5-nitropyrimidin-4-amine; N-(2-\{3-[(3,4-di } \\
\text { chlorophenyl)methyl]-2-oxo-1,3-diazina } \\
\text { EC }_{50, \mathrm{DPPH}}=50 \mathrm{mg} / \mathrm{mL} ; \mathrm{EC}_{50, \mathrm{DPPH}, \mathrm{AS}}=18 \mathrm{mg} / \mathrm{mL} ; \mathrm{RP}=0.81 \mathrm{mg} / \mathrm{g}\end{array}$ & [68] \\
\hline $\begin{array}{c}\text { Penicillium brevicompactum } \\
\text { EtOAc } \\
\text { RP-HPLC, UV, HRESIMS, NMR }\end{array}$ & $\begin{array}{l}\text { Anthranilic acid; syringic acid; sinapic acid; acetosyringone } \\
\qquad \mathrm{IC}_{50, \mathrm{DPPH}}=20-30 \mu \mathrm{g} / \mathrm{mL}\end{array}$ & [69] \\
\hline
\end{tabular}


Table 1. Cont.

\begin{tabular}{|c|c|c|}
\hline $\begin{array}{l}\text { Marine Organism } \\
\text { Extraction } \\
\text { Chemical Analysis }\end{array}$ & $\begin{array}{l}\text { Phenolic Compounds } \\
\text { Antioxidant Activity (When Provided) }\end{array}$ & Ref. \\
\hline $\begin{array}{c}\text { Penicillium janthinellum } \\
\text { EtOAc, MeOH } \\
\text { HPLC, UV, IR, HRESIMS, GC-MS, NMR }\end{array}$ & $\begin{array}{c}\text { 6-(2-Acetyl-3,5-dihydroxybenzyl)-4-hydroxy-3-methyl-2H-pyran-2-one; } \\
\text { 7-hydroxy-2-(hydroxymethyl)-5-methyl-4H-chromen4-one; } \\
\text { 3,5-dihydroxy-2-(2-(2-hydroxy-6-methylphenyl)-2-oxoethyl)-4-methylbenzaldehyde; } \\
\text { 3-hydroxy-5-methylphenyl 2,4-dihydroxy-6-methylbenzoate; lecanoric acid; orsellinic acid; orcinol }\end{array}$ & [70] \\
\hline $\begin{array}{c}\text { Penicillium griseofulvum } \\
\text { EtOAc, BuOH } \\
\text { HPLC, UV, IR, HRESIMS, NMR, OP }\end{array}$ & 4,6-Dimethylcurvulinic acid & [64] \\
\hline $\begin{array}{l}\text { Penicillium expansum } 091006 \text { from the mangrove plant } \\
\text { Excoecaria agallocha } \\
\text { EtOAc, AC } \\
\text { HPLC, UV, IR, HRESIMS, TLC, NMR, OP, ECD }\end{array}$ & $\begin{array}{l}\text { Phenolic bisabolane sesquiterpenoid and diphenyl ether units, expansols A and B, (S)-(+)-11-dehydrosydonic } \\
\text { acid,(7S,11S)-(+)-12-acetoxysydonic acid, (S)-(+)-sydonic acid, } \\
\text { diorcinol,(S)-(+)-2-[3-hydroxy-4-(2-methoxy-6-methylheptan-2-yl)benzyl]-5- } \\
\text { (3-hydroxy-5-methylphenoxy)-3-methylphenol, S-(+)-2-[3-hydroxy-4-(2-hydroxy-6- } \\
\text { methylheptan-2-yl)benzyl]-5-(3-hydroxy-5-methylphenoxy)-3-methylphenol, } \\
\text { (S)-(+)-3-hydroxy-4-(2-hydroxy-6-methylhept-6-en-2-yl)benzoic acid, and } \\
\text { 4-[(2S,6S)-7-acetoxy-2-hydroxy-6-methylheptan-2-yl]-3-hydroxybenzoic acid }\end{array}$ & [71] \\
\hline $\begin{array}{c}\text { Scopulariopsis sp. } \\
\text { EtOAc, MeOH, W, H } \\
\text { HPLC-PDA, RP-HPLC, LC-MS, HRESIMS, TLC, NMR, } \\
\text { OP }\end{array}$ & 12-Dimethoxypinselin; 12-O-acetyl-AGI-B4, 11,12-dihydroxysydonic acid; 1-hydroxyboivinianic acid & [72] \\
\hline $\begin{array}{l}\text { ZSDS1-F11 from the sponge Phakellia fusca } \\
\text { EtOAc, AC } \\
\text { TLC, CC, HRESIMS, NMR }\end{array}$ & Phenolic bisabolane sesquiterpenoid and diphenyl ether units; expansols A-F; diorcinol & [73] \\
\hline \multicolumn{3}{|c|}{ Cyanobacteria } \\
\hline $\begin{array}{l}\text { Anabaena C5 } \\
\text { E, US } \\
\text { HPLC-MS/MS }\end{array}$ & $\begin{aligned} \text { Quinic acid; } \text { catechin } \\
\mathrm{EC}_{50 \mathrm{DPPH}}=0.1 \mathrm{mg} / \mathrm{mL} ; \mathrm{FRAP}=11.4 \mathrm{mg} \mathrm{ASE} / \mathrm{g}\end{aligned}$ & [74] \\
\hline $\begin{array}{l}\text { Arthrospira S1, S2 } \\
\text { EtOH, US } \\
\text { HPLC-MS/MS }\end{array}$ & $\begin{array}{c}\text { Catechin } \\
\mathrm{EC}_{50, \mathrm{DPPH}}=0.1 \mathrm{mg} / \mathrm{mL} ; \mathrm{FRAP}=15.1-21.0 \mathrm{mg} \text { ASE } / \mathrm{g}\end{array}$ & [74] \\
\hline $\begin{array}{l}\text { Calothrix sp. SI-SV } \\
\text { MeOH, W } \\
\text { HPLC-UV/VIS }\end{array}$ & $\begin{array}{l}\text { Rutin; tannic acid; orcinol; phloroglucinol; protocatechuic acid } \\
\qquad \mathrm{EC}_{50, \mathrm{ABTS}}=65.79 \mu \mathrm{g} / \mathrm{mL}, \mathrm{EC}_{50, \mathrm{DPPH}}=69.38 \mu \mathrm{g} / \mathrm{mL}\end{array}$ & [75] \\
\hline $\begin{array}{l}\text { Leptolyngbya sp. } \\
\text { MeOH, W } \\
\text { HPLC-UV/VIS }\end{array}$ & $\begin{array}{l}\text { Rutin; tannic acid; orcinol; phloroglucinol; protocatechuic acid } \\
\text { SI-SM }\left(\mathrm{EC}_{50, \mathrm{ABTS}}=63.45, \mathrm{EC}_{50, \mathrm{DPPH}}=67.49 \mu \mathrm{g} / \mathrm{mL}\right)\end{array}$ & [75] \\
\hline $\begin{array}{l}\text { Nostoc commune } \\
\text { MeOH, W } \\
\text { RP-HPLC-DAD }\end{array}$ & Gallic and chlorogenic acids & [76] \\
\hline $\begin{array}{l}\text { Nostoc sp } \\
\text { EtOH, US } \\
\text { HPLC-MS/MS }\end{array}$ & $\begin{array}{l}\text { Gallic acid; chlorogenic acid; quinic acid; catechin; epicatechin; kaempferol; rutin; apiin } \\
\qquad \mathrm{IC}_{50, \mathrm{DPPH}}=0.04-9.47 \mathrm{mg} / \mathrm{mL} ; \mathrm{FRAP}=8.4-13.7 \mathrm{mg} \mathrm{ASE} / \mathrm{g}\end{array}$ & [74] \\
\hline
\end{tabular}


Table 1. Cont.

\begin{tabular}{|c|c|c|}
\hline $\begin{array}{l}\text { Marine Organism } \\
\text { Extraction } \\
\text { Chemical Analysis }\end{array}$ & $\begin{array}{l}\text { Phenolic Compounds } \\
\text { Antioxidant Activity (When Provided) }\end{array}$ & Ref. \\
\hline \multicolumn{3}{|c|}{ Microalgae } \\
\hline $\begin{array}{l}\text { Ankistrodesmus sp. } \\
\text { MeOH, W } \\
\text { RP-HPLC-DAD }\end{array}$ & $\begin{array}{c}\text { Protocatechuic acid } \\
\text { DPPH scavenging } 10 \mathrm{mg} / \mathrm{mL}=29 \%\end{array}$ & [76] \\
\hline $\begin{array}{l}\text { Euglena cantabrica } \\
\text { MeOH, W } \\
\text { RP-HPLC-DAD }\end{array}$ & $\begin{array}{l}\text { Gallic acid; protocatechuic acid; chlorogenic acid; }(+) \text { catechin; (-)epicatechin } \\
\text { DPPH scavenging } 10 \mathrm{mg} / \mathrm{mL}=71 \%\end{array}$ & [76] \\
\hline $\begin{array}{l}\text { Nannochloropsis sp. } \\
\text { EtOH, MeOH, H } \\
\text { RP-HPLC-UV } \\
\text { HPLC-ESI-MS/MS }\end{array}$ & Phenolic acids: chlorogenic; caffeic; gallic; protocatechuic; hydroxybenzoic; syringic; vanillic; ferulic & [27] \\
\hline $\begin{array}{l}\text { Spirulina sp. } \\
\text { RP-HPLC-UV } \\
\text { HPLC-ESI-MS/MS }\end{array}$ & Protocatechuic; gallic; chlorogenic; vanillic; hydroxybenzoic; syringic; vanillic acids & [27] \\
\hline $\begin{array}{l}\text { Spirogyra sp. } \\
\text { MeOH, W } \\
\text { RP-HPLC-DAD }\end{array}$ & $\begin{array}{c}\text { Gallic acid } \\
\text { DPPH scavenging } 10 \mathrm{mg} / \mathrm{mL}=62 \%\end{array}$ & [76] \\
\hline \multicolumn{3}{|c|}{ Seagrasses } \\
\hline $\begin{array}{c}\text { Cymodocea nodosa } \\
\text { MeOH, CH } \mathrm{CL}_{2} \\
\text { HPLC-DAD, LC/MS-ESI, NMR }\end{array}$ & Diosmetin 7-sulfate; caftaric acid; coutaric acid & [77] \\
\hline $\begin{array}{l}\text { Halodule wrightii, Thalassia testudinum } \\
\text { Agar, } \mathrm{W} \\
\text { HPLC }\end{array}$ & p-hydroxybenzoic acid; ferulic acid; p-coumaric acid; syringic acid; gallic acid & [78] \\
\hline $\begin{array}{l}\text { Halophila stipulacea } \\
\text { MeOH, EtOAc, Hexane } \\
\text { HR-LC-MS/MS } \\
\text { GNPS }\end{array}$ & $\begin{array}{l}\text { Luteolin; apigenin; matairesinol; cirsimarin; spiraeoside; 2,4-dihydroxyheptadec-16-ynyl acetate; } \\
\text { 3-hydroxy-4-methoxycinnamic acid, alpha-cyano-4-hydroxycinnamic }\end{array}$ & [79] \\
\hline $\begin{array}{l}\text { Posidonia oceanica }(\mathrm{L} .) \\
\text { EtOH, W, Formic acid } \\
\text { HPLC-ESI-MS/MS }\end{array}$ & $\begin{array}{l}\text { Procyanidin B2; procyanidin C2; isorhamnetin-3-O-glucoside; quercetin-3-O-glucoside; } \\
\text { quercetin-3-O-malonylglucoside; isorhamnetin-3-O-malonylglucoside } \\
\qquad \mathrm{EC}_{50, \mathrm{DPPH}}=32 \mu \mathrm{g} / \mathrm{mL}\end{array}$ & [80] \\
\hline $\begin{array}{c}\text { Ruppia cirrhosa (Petagna) Grande, Ruppia maritima L. } \\
\text { MeOH, W, EtOAc } \\
\text { HPLC-DAD, } \\
\text { HR-LCMS-ESI+/TOF, NMR }\end{array}$ & $\begin{array}{c}\text { Chicoric acid; quercetin 3-O- } \beta \text {-D-(6"-O-malonyl)-glucopyranoside; quercetin 3-O- } \beta \text {-D-galactopyranoside; } \\
\text { quercetin 3-O- } \beta \text {-D-glucopyranoside; quercetin 3-O- } \beta \text {-D-(6"-O-malonyl)galactopyranoside; isorhamnetin } \\
\text { 3-O- } \beta \text {-D-galactopyranoside; isorhamnetin 3-O- } \beta \text {-D-glucopyranoside; isorhamnetin 3-O- } \beta \text {-D-(6"-O-malonyl) } \\
\text { galactopyranoside; isorhamnetin 3-O- } \beta \text {-D- }\left(6^{\prime \prime}-O-\text { malonyl)-glucopyranoside }\right. \\
\text { EC } 50 \text { DPPH }=23-176 \mu \mathrm{g} / \mathrm{mL}\end{array}$ & [81] \\
\hline
\end{tabular}


Table 1. Cont.

\begin{tabular}{|c|c|c|}
\hline $\begin{array}{l}\text { Marine Organism } \\
\text { Extraction } \\
\text { Chemical Analysis }\end{array}$ & $\begin{array}{l}\text { Phenolic Compounds } \\
\text { Antioxidant Activity (When Provided) }\end{array}$ & Ref. \\
\hline $\begin{array}{l}\text { Syringodium isoetifolium } \\
\text { MeOH } \\
\text { HPLC-EI-MS }\end{array}$ & $\begin{array}{c}\text { Caftaric acid; } 2 \text { 3-(4-Hydroxyphenyl)lactic acid; caffeic acid; caffeoyl-4'-O-phenyllactate; 3-phenyllactic acid; } \\
\text { 4-coumaric acid; chicoric acid } \\
\text { DPPH = } 5.4 \mathrm{mg} \mathrm{TE} / \mathrm{g} ; \mathrm{ABTS}=9.6 \mathrm{mg} \text { TE; } \text { CUPRAC }=18.7 \mathrm{mg} \mathrm{TE} / \mathrm{g} ; \mathrm{FRAP}=9.5 \mathrm{mgTE} / \mathrm{g} ; \\
\text { Chelating ability }=9.17 \mathrm{mg} \text { EDTAE } / \mathrm{g}\end{array}$ & [82] \\
\hline $\begin{array}{l}\text { Thalassia testudinum } \\
\text { AC, W, AA }\end{array}$ & 3,4-Dihydroxybenzoic acid; p-hydroxybenzoic acid; p-coumaric acid; vanillin & [83] \\
\hline $\begin{array}{l}\text { T. testudinum } \\
\text { EtOH, W } \\
\text { RP-HPLC } \\
\text { LC-MS, NMR }\end{array}$ & 3,4-Dihydroxybenzoic acid, p-hydroxybenzoic acid, p-coumaric acid and vanillin & [84] \\
\hline $\begin{array}{l}\text { Zostera asiatica and Z. marina } \\
\text { HPLC-MS }\end{array}$ & $\begin{array}{c}\text { Rosmarinic acid; luteolin; } 7,3^{\prime} \text {-disulfate luteolin } \\
\text { ROS scavenger; protecting or enhancing endogenous antioxidants; metal chelation }\end{array}$ & [85] \\
\hline $\begin{array}{l}\text { Z. marina } \\
\text { Hexane, AC } \\
\text { HPLC-MS, NMR }\end{array}$ & Deoxycymodienol; isotedarene A & [86] \\
\hline $\begin{array}{l}\text { Z. marina } \\
\text { SPA, IPA } \\
\text { HPLC-MS/MS }\end{array}$ & $\begin{array}{l}\text { 3-Hydroxyhexanoic acid; 4-hydroxynonenoic acid; p-coumaric acid; caffeic acid; ferulic acid; zosteric acid; } \\
\text { apigenin; luteolin; diosmetin; apigenin-7-sulfate; rosmarinic acid; luteolin-7-sulfate; diosmetin-7-sulfate; } \\
\text { kaempferol-7,4'-dimethylether-3-O-sulfate }\end{array}$ & [5] \\
\hline $\begin{array}{l}\text { Z. noltii } \\
\text { MeOH } \\
\text { HPLC, NMR }\end{array}$ & Rosmarinic acid; caffeic acid; zosteric acid & [87] \\
\hline $\begin{array}{c}\text { Z. noltei } \\
\text { MeOH } \\
\text { HPLC-PDA-MS-ESI-QTOF, NMR }\end{array}$ & $\begin{array}{l}\text { Rosmarinic acid; apigenin-7-O-glucoside; luteolin; apigenin; diosmetin; acacetin; luteolin-7-sulfate; } \\
\text { apigenin-7-sulfate; diosmetin-7-sulfate; acacetin-7-sulfate }\end{array}$ & [88] \\
\hline $\begin{array}{c}\text { Zostera noltei leaves } \\
\text { MeOH, W } \\
\text { HPLC-DAD, LC-MS, NMR }\end{array}$ & Apigenin 7-sulfate; diosmetin 7-sulfate & [89] \\
\hline Zostera noltii, Z. marina & $\begin{array}{l}\text { Apigenin 7-sulphate; luteolin 7-sulphate; diosmetin 7-sulphate; rosmarinic acid; luteolin 7-glucoside; apigenin } \\
\text { 7-glucoside; apigenin; luteolin 7-(6"'-malonyl) glucoside; apigenin 7-(6"'-malonyl) glucoside }\end{array}$ & [81] \\
\hline $\begin{array}{l}\text { Zostera muelleri } \\
\text { MeOH, AA } \\
\text { RP-HPLC }\end{array}$ & Proanthocyanidins; gallic acid; rosmarinic acid & [90] \\
\hline \multicolumn{3}{|c|}{ Sponges } \\
\hline $\begin{array}{l}\text { Didiscus aceratus } \\
\text { MeOH, } \mathrm{CH}_{2} \mathrm{Cl}_{2}, \mathrm{H} \\
\text { HRESIMS, NMR }\end{array}$ & $\begin{array}{c}\text { (S)-(+)-Curcuphenol; 10ß-hydroxycurcudiol; 10 } \alpha \text {-hydroxycurcudiol; dicurcuphenols A-E; dicurcuphenol } \\
\text { ether F }\end{array}$ & [91] \\
\hline
\end{tabular}


Table 1. Cont.

\begin{tabular}{|c|c|c|}
\hline $\begin{array}{l}\text { Marine Organism } \\
\text { Extraction } \\
\text { Chemical Analysis }\end{array}$ & $\begin{array}{l}\text { Phenolic Compounds } \\
\text { Antioxidant Activity (When Provided) }\end{array}$ & Ref. \\
\hline $\begin{array}{l}\text { Hyrtios erectus } \\
\text { MeOH, EtOAc } \\
\text { HRAPCIMS, HRESIMS, NMR }\end{array}$ & Phenolic alkenes; erectuseneols A-F & [92] \\
\hline $\begin{array}{l}\text { Myrmekioderma sp. } \\
\mathrm{MeOH}, \mathrm{CH}_{2} \mathrm{Cl}_{2} \text {, EtOAc, BuOH, hexane } \\
\text { HRESIMS, NMR }\end{array}$ & $\begin{array}{c}\text { 1-(2,4-Dihydroxy-5-methylphenyl)ethan-1-one; (1'Z)-2-(1',5'-dimethylhexa-1', } 4^{\prime} \text {-dieny1)-5- } \\
\text { methylbenzene-1,4-diol; 1,8-epoxy-1(6),2,4,7,10-bisaborapentaen-4-ol; 6-(3-hydroxy-6-methyl-1,5- } \\
\text { heptadien-2-yl)-3-methylbenzene-1,4-diol; 4-hydroxy-3,7-dimethyl-7-(3-methylbut-2- } \\
\text { en-1-yl)benzofuran-15-one; 6-(2-methoxy-6-methylhept-5-en-2-yl)-3-methylbenzene-1,4-diol; } \\
\text { 9-(3,3-dimethyloxiran-2-yl)-1,7-dimethyl-7-chromen-4-ol }\end{array}$ & [93] \\
\hline $\begin{array}{l}\text { Myrmekioderma sp. } \\
\text { MeOH, EtOAc } \\
\text { HRAPCIMS, HRESIMS, NMR }\end{array}$ & $\begin{array}{l}\text { (R)-Biscurcudiol; (S)-biscurcudiol; myrmekiodermaral; myrmekioperoxide A; myrmekioperoxide B (4); } \\
\text { myrmekiodermaral; (+)-curcudiol; (+)-dehydrocurcudiol; abolene; abolene epimer at C-5'; (+)-oxoabolen; } \\
\text { (+)-curcuphenol; } 5^{\prime} \alpha \text {-hydroxycurcudiol; } 5^{\prime} \beta \text { - hydroxycurcudiol; curcuepoxide A; curcuepoxide B }\end{array}$ & [94] \\
\hline
\end{tabular}

AA: ascorbic acid; AC: acetone; ASE: ascorbic acid equivalents; BuOH: butanol; CA: chelating ability; CAA: antioxidant assay for cellular antioxidant activity [95]; CLPAA: cellular lipid peroxidation antioxidant activity assay [95]; EA: ethyl acetate; ECD: electronic circular dichroism; EtOAc: ethyl acetate; EtOH: ethanol; GNPS: global natural product social molecular networking; H: hexane; HRAPCIMS: high resolution atmospheric pressure chemical ionization mass spectrometry; HRESIMS: high resolution electrospray ionization mass spectrometry; IPA: isopropanol; LPIA: lipid peroxidation inhibition assay [96]; MeCN: acetonitrile; MeOH: methanol; OP: polarimetry; PDA: photodiode array; PGU: phloroglucinol units; RP: reducing power; RP-HPLC: reversed phase HPLC; SPA: solid phase adsorption; SRSA: superoxide radical scavenging assay [96]; TAA: total antioxidant capacity [97]; TLC: thin-layer chromatography; US: ultrasound; W: water. 


\subsubsection{Macroalgae}

Bromophenols

Among the halogenated secondary metabolites synthesized by seaweeds, brominated ones are more usual due to the availability of chloride and bromide ions in seawater; iodine and fluorine are less frequent. Whereas iodination can be found in brown algae, bromine or chlorine metabolites are more abundant in red and in green seaweeds [98]. The most abundant bromophenolic compounds found in macroalgae are bromophenols and their transformation products bromoanisoles, hydroxylated and methoxylated bromodiphenyl ethers and polybrominated dibenzo-p-dioxins [2,37]. Other brominated compounds have also been identified in macroalgae, such as brominated sesquiterpenes [99].

Some bromophenols identified in seaweeds are shown in Tables 2 and 3. Specifically, 2,4,6-tribromophenol is widely distributed, coming from environmental contaminants, pesticides and from marine organisms, which produce it as a defense against predators and biofouling. Machado et al. [100] found bromoform $(1.7 \mathrm{mg} / \mathrm{g})$, dibromochloromethane $(15.8 \mu \mathrm{g} / \mathrm{g})$, bromochloroacetic acid $(9.8 \mu \mathrm{g} / \mathrm{g})$ and dibromoacetic acid $(0.9 \mu \mathrm{g} / \mathrm{g})$ in Asparagopsis taxiformis, and Bidleman et al. [37] found bromoanisols at more than $1000 \mathrm{pg} / \mathrm{g}$ in Ascophyllum nodosum, Ceramium tenuicorne, Ceramium virgatum, Fucus radicans, Fucus serratus, Fucus vesiculosus, Saccharina latissima, Laminaria digitata, and Acrosiphonia/Spongomorpha sp. The presence of these compounds can be associated with off-flavors. Among the bromophenols identified in prawn species, probably obtained from marine algae and bryozoan from the diet, are 2-and 4-bromophenol, 2,4-dibromophenol, 2,4,6-tribromophenol and 2,6-dibromophenol. The latter confers an iodoform off-flavor at $60 \mathrm{ng} / \mathrm{kg}$ and it was found in prawn, reaching more than $200 \mu \mathrm{g} / \mathrm{kg}$ in the eastern $\mathrm{king}$ prawn. This off-flavor can be reduced by handling and processing [101]. Kim et al. [102] reported that 3-bromo-4,5-dihydroxybenzaldehyde exerted antioxidant effects in skin cells subjected to oxidative stress, by increasing the protein and mRNA levels of glutathione synthesizing enzymes, enhancing the production of reduced glutathione in $\mathrm{HaCaT}$ cells and protecting cells against oxidative stress via the activation of the NF-E2-related factor.

Their extraction can be achieved with organic solvents, i.e., methanol or methanol-dichloromethane [37], but yields can vary with other factors. Seasonal variations and different profiles among species, locations and environmental conditions have been observed [40], their production being induced by environmentally stressing conditions, such as the presence of herbivores and the elevated levels of light and salinity [2].

\section{Simple Phenolics}

The presence of benzoic and cinnamic acids has been reported, particularly in brown seaweeds, which also present flavonoids $[20,103]$. Brown seaweeds present higher contents of benzoic and cinnamic acids $(1 \mathrm{mg} / \mathrm{g})$ than red $(0.23 \mathrm{mg} / \mathrm{g})$ and green $(0.01-0.9 \mathrm{mg} / \mathrm{g})$ seaweeds $[26,104,105]$. Higher values (1-9 mg/g) have been reported for gallic acid in green and red seaweeds [106]. These authors reported catechin content up to $14 \mathrm{mg} / \mathrm{g}$ in red seaweeds and up to $11.5 \mathrm{mg} / \mathrm{g}$ in green ones, whereas in brown seaweeds reached up to $11 \mathrm{mg} / \mathrm{g}$. Phloroglucinol derivatives are the major phenolics in brown seaweeds, and flavonoids account for $35 \%$ of the total, the most abundant being gallic, chlorogenic acid, caffeic acid, ferulic acid [20].

The phenolic levels correlated positively with elevated irradiance exposure and temperature and their content differs among different parts of the seaweed. Extracts of the thallus were more active than extracts of the receptacles, and the solvent was also important, the best being acetone, ethanol, and water. The drying stage should also be optimized, since degradation may occur, i.e., dried material provided lower yield and less active extracts than frozen ones [24]. 
Table 2. Phenolic compounds found in brown seaweeds.

\begin{tabular}{|c|c|c|}
\hline $\begin{array}{c}\text { Seaweed } \\
\text { Extraction } \\
\text { Chemical Analysis }\end{array}$ & $\begin{array}{l}\text { Compounds } \\
\text { Antioxidant Activity (When Provided) }\end{array}$ & Ref. \\
\hline $\begin{array}{l}\text { A. nodosum, F. spiralis } \\
\text { MeOH, AC, Hexane } \\
\text { UPLC, MS, NMR }\end{array}$ & Phlorotannins (4-6, 9-12 PGU) & [107] \\
\hline $\begin{array}{l}\text { A. nodosum, Fucus spiralis, F. vesiculosus, Pelvetia canaliculata, } \\
\text { Saccharina longicruris } \\
\text { MeOH, W } \\
\text { UPLC, HRMS }\end{array}$ & Phlorotannins (3-50 PGU) & [108] \\
\hline $\begin{array}{l}\text { Carpophyllum flexuosum, Carpophyllum plumosum, Ecklonia radiata } \\
\text { W, MAE } \\
\text { HPLC-DAD-ESI-MS, NMR }\end{array}$ & $\begin{array}{l}\text { Bifuhalol, bifuhalol dimer, bifuhalol trimer, hydroxytrifuhalol, trifuhalol, tetrafuhalol } \\
\text { DPPH = 2.7-37.4 mg GAE/g; FRAP = 4.4-62.1 mg GAE/g }\end{array}$ & [109] \\
\hline $\begin{array}{l}\text { Cystoseira barbata } \\
\text { TFA, W } \\
\text { LC-QTOF-MS }\end{array}$ & $\begin{array}{l}\text { Phloroglucinol, rutin, phlorofucofuroeckol, 3-O-rutinosyl-kaempferol, catechin-catechin-O-gallate, } \\
\text { gallocatechin, gallocatechin- } O \text {-glucuronide, 1-hydroxy-2-( } \beta \text {-D-glucopyranosyloxy)-9,10 anthraquinone, } \\
\text { 2-O-O-(6,9,12-octadecatrienoyl)-3-O-(nonadecanoyl)glyceryl } \beta \text {-galactopyranoside, chlorogenic acid butyl ester, } \\
\text { phloroglucinol, quercetin } \\
\mathrm{EC}_{50, \mathrm{DPPH}}=11.7 \mu \mathrm{g} / \mathrm{mL} ; \mathrm{EC}_{50, \mathrm{OH}}=11.4 \mu \mathrm{g} / \mathrm{mL} ; \mathrm{EC}_{50, \mathrm{RP}}=51 \mathrm{~g} / \mathrm{mL} ; \mathrm{EC}_{50, \mathrm{CA}}=40 \mathrm{~g} / \mathrm{mL}\end{array}$ & {$[110]$} \\
\hline $\begin{array}{c}\text { C. barbata } \\
\text { AC, MeOH, W } \\
\text { UHPLC-DAD-QTOF-MS }\end{array}$ & $\begin{array}{c}\text { Fucophlorethol and eckol derivatives }(3-7 \text { PGU) } \\
\mathrm{EC}_{50, \mathrm{DPPH}}=14 \mu \mathrm{g} / \mathrm{mL} ; \mathrm{EC}_{50, \mathrm{ABTS}}=0.5 \mu \mathrm{M} \text { Trolox; } \mathrm{EC}_{50, \mathrm{RP}}=16-35 \mu \mathrm{g} / \mathrm{mL}\end{array}$ & [111] \\
\hline $\begin{array}{c}\text { Cystoseira nodicaulis, Cystoseira tamariscifolia, Cystoseira usneoides, } \\
\text { F. spiralis } \\
\text { AC, Hexane, } W \\
\text { HPLC-DAD-ESI-MS }\end{array}$ & $\begin{array}{l}\text { Fucophloroethol, fucodiphloroethol, fucotriphloroethol, 7-phloroeckol, phlorofucofuroeckol, bieckol, dieckol } \\
\qquad \mathrm{EC}_{50, \mathrm{SRSA}}=0.93-4.02 \mathrm{mg} / \mathrm{mL} ; \mathrm{EC}_{50, \mathrm{LPIA}}=2.32->9.1 \mathrm{mg} / \mathrm{mL}\end{array}$ & [96] \\
\hline $\begin{array}{c}\text { Cystoseira nodicaulis, F. serratus, F. vesiculosus, Himanthalia elongata } \\
\text { EtOH, W } \\
\text { UPLC-ESI-MS }\end{array}$ & $\begin{aligned} & \text { Phlorotannin }(3-16 \text { PGU }) \\
& \mathrm{EC}_{50, \mathrm{DPPH}}= 4-28 \mu \mathrm{g} / \mathrm{mL} ; \mathrm{FRAP}=101-307 \mu \mathrm{g} \text { TE/mg }\end{aligned}$ & [21] \\
\hline $\begin{array}{l}\text { Durvillaea antarctica, Lessonia spicata } \\
\text { EtOH, EE, EtOAc, W } \\
\text { HPLC-MS-MRM }\end{array}$ & $\begin{array}{c}\text { Phlorotannin (3-8 PGU), flavonoids } \\
\mathrm{EC}_{50, \mathrm{DPPH}}=0.97-1.24 \mathrm{mg} / \mathrm{mL} ; \mathrm{FRAP}=2.95-6.20 \mathrm{mM} \mathrm{TE} / \mathrm{kg} ; \\
\text { ORAC }=4.75-25.9 \mu \mathrm{M} \mathrm{TE} / \mathrm{g}\end{array}$ & [112] \\
\hline $\begin{array}{l}\text { Eisenia bicyclis } \\
\text { EtOH } \\
\text { HPLC-PDA }\end{array}$ & Eckol, phlorofucofuroeckol-A, dieckol, 6,6'-bieckol, 8,8'-bieckol & [113] \\
\hline $\begin{array}{l}\text { Ecklonia cava } \\
\text { EtOH } \\
\text { UPLC-PDA }\end{array}$ & Phloroglucinol, eckol, eckstolonol, triphlorethol-A, dieckol & {$[114]$} \\
\hline
\end{tabular}


Table 2. Cont

\begin{tabular}{|c|c|c|}
\hline $\begin{array}{c}\text { Seaweed } \\
\text { Extraction } \\
\text { Chemical Analysis }\end{array}$ & $\begin{array}{l}\text { Compounds } \\
\text { Antioxidant Activity (When Provided) }\end{array}$ & Ref. \\
\hline $\begin{array}{c}\text { E. cava } \\
\text { EtOH, US } \\
\text { HPLC-DAD-ESI/MS, NMR }\end{array}$ & Dieckol, phlorofucofuroeckol-A, 2,7-phloroglucinol-6,6-bieckol, pyrogallol-phloroglucinol-6,6-bieckol & [115] \\
\hline $\begin{array}{l}\text { E. cava } \\
\text { EtOH, W } \\
\text { RP-HPLC }\end{array}$ & $\begin{array}{c}\text { Dieckol } \\
\mathrm{ABTS}=1.3 \mathrm{~g} \mathrm{VCE} / \mathrm{g} ; \mathrm{DPPH}=0.4 \mathrm{~g} \mathrm{VCE} / \mathrm{g}\end{array}$ & [116] \\
\hline $\begin{array}{l}\text { Ecklonia stolonifera } \\
\text { EtOH, W } \\
\text { HPLC-PDA, NMR }\end{array}$ & $\begin{array}{c}\text { 2-phloroeckol, dioxinodehydroeckol, eckol, phlorofucofuroeckol B, 6,6'-bieckol, dieckol, 974-B, } \\
\text { phlorofucofuroeckol A }\end{array}$ & [117] \\
\hline $\begin{array}{c}\text { F. vesiculosus } \\
\text { MeOH, W } \\
\text { Q-ToF-MS, UPLC-TQD-MS/MS-MRM }\end{array}$ & $\begin{array}{l}\text { Phlorotannins }(3-18 \text { PGU) } \\
\mathrm{EC}_{50, \mathrm{DPPH}}=18.2 \mu \mathrm{g} / \mathrm{mL}\end{array}$ & [118] \\
\hline $\begin{array}{l}\text { F. vesiculosus } \\
\text { AC, EtOAc, EtOH, MeOH, W } \\
\text { HPLC-DAD-ESI/MS }{ }^{n}\end{array}$ & $\begin{array}{l}\text { Fucodiphlorethol A, trifucodiphlorethol isomers, phlorotannins (3-10 PGU) } \\
\mathrm{EC}_{50, \mathrm{DPPH}}=2.79-4.23 \mu \mathrm{g} / \mathrm{mL} ; \mathrm{Fe}^{2+}-\mathrm{CA}=25.1-47.6 \% ; \mathrm{RP}=17.8-910.7 \mathrm{mg} \text { ASEs } / \mathrm{g}\end{array}$ & [119] \\
\hline $\begin{array}{l}\text { F. vesiculosus } \\
\text { AC, W } \\
\text { UPLC-DAD-ESI/MS }\end{array}$ & $\begin{array}{l}\text { Fucols, fucophlorethols, fuhalols, phlorotannin derivatives (3-22 PGU), fucofurodiphlorethol, } \\
\text { fucofurotriphlorethol, fucofuropentaphlorethol }\end{array}$ & [120] \\
\hline $\begin{array}{l}\text { Halidrys siliquosa } \\
\text { AC, } \mathrm{W} \\
\text { MALDI-TOF-MS, NMR }\end{array}$ & $\begin{array}{c}\text { Diphlorethol, triphlorethol, trifuhalol, tetrafuhalol } \\
\mathrm{EC}_{50, \mathrm{DPPH}}=0.02-1.00 \mathrm{mg} / \mathrm{mL} ; \mathrm{EC}_{50, \mathrm{RP}}=0.06-0.62 \mathrm{mg} / \mathrm{mL} ; \mathrm{EC}_{50, \mathrm{NBT}}=0.66-2.44 \mathrm{mg} / \mathrm{mL} ; \\
\mathrm{ORAC}=5.39 \mu \mathrm{mol} \mathrm{TE} / \mathrm{mg} ; \mathrm{BCB}=0.21-1.50 \mathrm{~g} / \mathrm{mL}\end{array}$ & [121] \\
\hline $\begin{array}{c}\text { H. elongata } \\
\text { MeOH, W } \\
\text { HPLC-DAD, HPLC-ESI-MS/MS }\end{array}$ & $\begin{array}{l}\text { Phloroglucinol, gallic acid, chlorogenic acid, caffeic acid, ferulic acid, hydroxybenzaldehyde, kaempferol, } \\
\text { myricetin, quercetin } \\
\qquad \mathrm{EC}_{50, \mathrm{DPPH}}=14.5 \mu \mathrm{g} / \mathrm{mL}\end{array}$ & [20] \\
\hline $\begin{array}{c}\text { Hydroclathrus clathratus, Padina minor, Padina sp., } \\
\text { Sargassum oligosystum, Sargassum aff. bataanens, Sargassum sp. } \\
\text { MeOH, W } \\
\text { GC-MS-EI-SIM }\end{array}$ & 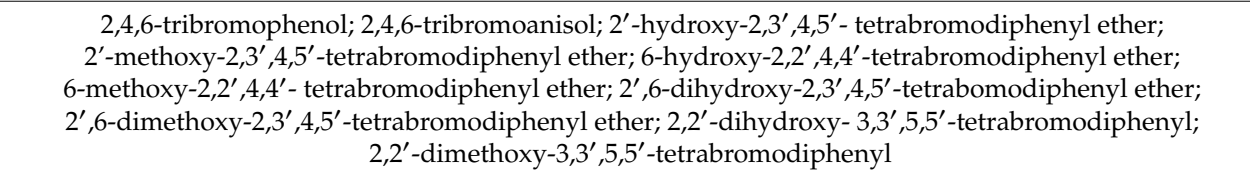 & [122] \\
\hline $\begin{array}{c}\text { L. digitata } \\
\text { MeOH, W } \\
\text { RP-UPLC-UV-MS }{ }^{n}, \text { MALDI-TOF-MS, NMR }\end{array}$ & $\begin{array}{l}\text { Di-fuhalols (6-7 PGU), fucols (3-7 PGU), fucophlorethols (3-16 PGU), fuhalols (4-5 PGU), } \\
\text { phlorethols (3-18 PGU) }\end{array}$ & [123] \\
\hline
\end{tabular}


Table 2. Cont.

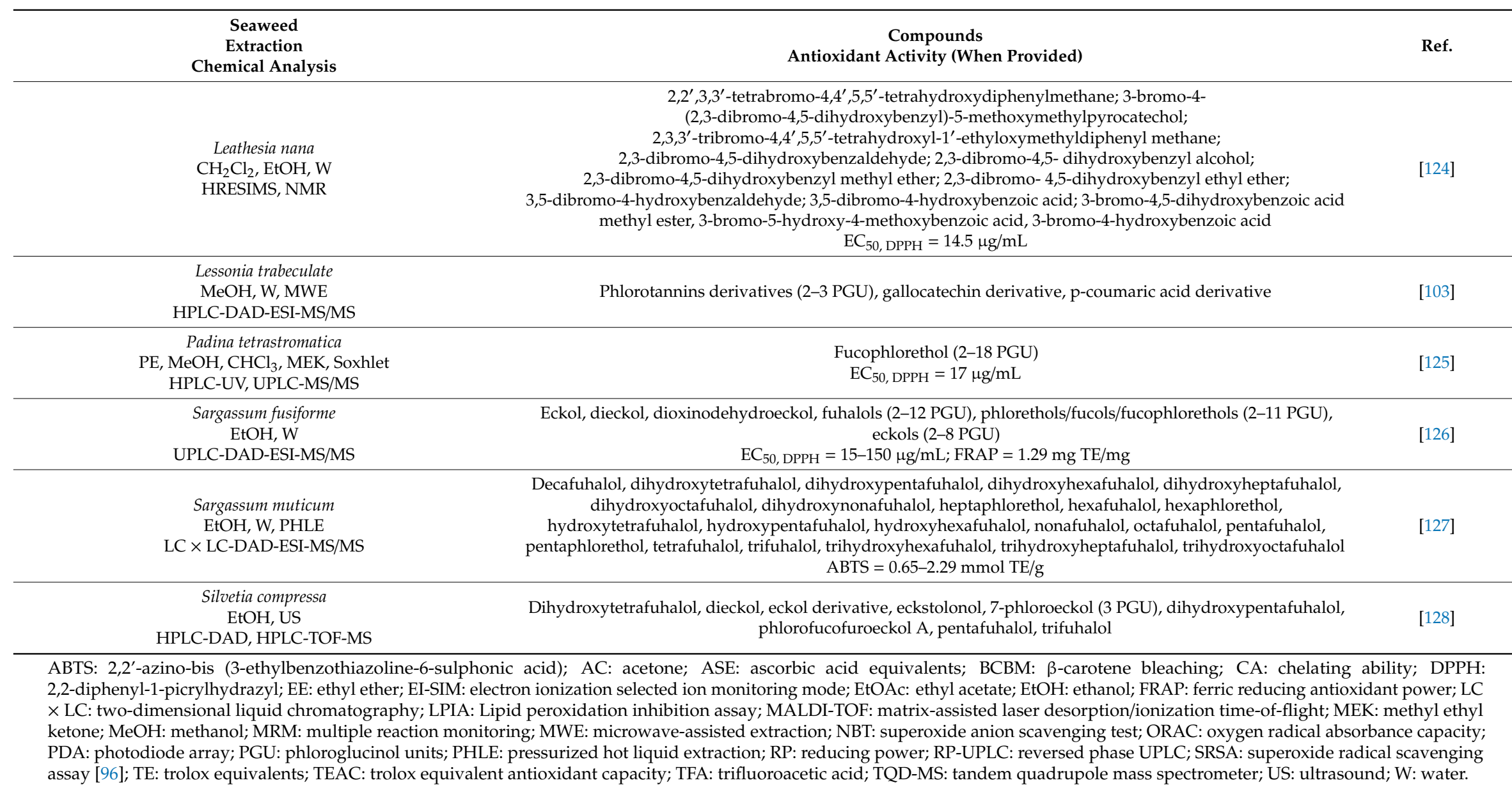


Phlorotannins

These are structural components of the cell wall in brown algae, and also play a function in macroalgal chemical defense comparable to those of secondary metabolites, such as protection from UV radiation and defense against grazing [4]. The species and cultivation conditions affect the composition. Lopes et al. [7] found five and six ringed phloroglucinol oligomers in wild grown and aquaculture-grown F. vesiculosus, trimers and tetramers in extracts from Fucus guiryi, F. serratus and F. spiralis. Fucophlorethols are dominant in Fucus sp, exhibiting molecular weights ranging from 370 to $746 \mathrm{Da}$, and relatively low degree of polymerization (3-6 phloroglucinol units, PGU). Moreover, isomers of fucophlorethol, dioxinodehydroeckol, difucophlorethol, fucodiphlorethol, bisfucophlorethol, fucofuroeckol, trifucophlorethol, fucotriphlorethol, tetrafucophlorethol, and fucotetraphlorethol were identified.

Heffernan et al. [21] reported that most low molecular weight (LMW) phlorotannins presented 4-16 monomers of phloroglucinol. The level of isomerization differed among macroalgal species and F. vesiculosus showed up to 61 compounds with 12 PGU. Species-specific phenolic profiles, with varying degrees of composition, polymerization and isomerization have been described and the antiradical activity observed was not only due to higher phlorotannin concentrations but to their geometric arrangement and the position of the free hydroxyl groups [4]. F. vesiculosus low molecular weight fractions were predominantly composed of phlorotannins between 498 and 994 Da (4-8 PGUs), in P. canaliculata most structures presented 9-14 PGUs, whereas in H. elongata most phlorotannins were composed of 8-13 PGU.

The influence of the solvent has been reported in a number of studies either as extractant or as fractionation medium, i.e., Murugan and Iyer [129] found higher ferrous ion chelation and growth inhibition of MG-63 cells by methanolic and aqueous extracts from Caulerpa peltata, Gelidiella acerosa, Padina gymnospora, and S. wightii. However, the higher extraction of phenols and flavonoids was found with chloroform and ethyl acetate, as well as the DPPH radical scavenging and growth inhibitory activities in cancer cells. Aravindan et al. [130] selected dichloromethane and ethyl acetate fractions from Dictyota dichotoma, Hormophysa triquerta, Spatoglossum asperum, Stoechospermum marginatum and P. tetrastromatica for their high levels of phenolics, antioxidants and inhibitors of pancreatic tumorigenic cells (MiaPaCa-2, Panc-1, BXPC-3 and Panc-3.27) growth. The use of intensification techniques can enhance the extraction yields. Kadam et al. [16] reported that under ultrasound-assisted extraction of $A$. nodosum in acidic media, the extraction of high molecular weight phenolic compounds was facilitated. However, other bioactives were also solubilized in a short time and crude solvent extracts contained several non-phenolic components, such as carbohydrates, amino acids and pigments. Further purification strategies have been tried, i.e., a multistep scheme with successive precipitation of lipophilic compounds and further chromatographic fractionation [24], solvent partition and membrane fractionation [21], solvent partition and column chromatography [19,22], adsorption, washing and further elution [131], or chromatography and then membrane processing by ultrafiltration and dialysis [132]. 
Table 3. Phenolic compounds found in red and green seaweeds.

\begin{tabular}{|c|c|c|}
\hline $\begin{array}{l}\text { Seaweed } \\
\text { Extraction } \\
\text { Chemical Analysis }\end{array}$ & $\begin{array}{l}\text { Compounds } \\
\text { Antioxidant Activity (When Provided) }\end{array}$ & Ref. \\
\hline \multicolumn{3}{|c|}{ Green seaweeds } \\
\hline $\begin{array}{l}\text { Caulerpa lentillifera, C. taxifolia, Chaetomorpha crassa, Chara sp., } \\
\text { Chlorodesmis sp., Cladophora sp. } \\
\text { MeOH, W } \\
\text { GC-MS-EI-SIM }\end{array}$ & 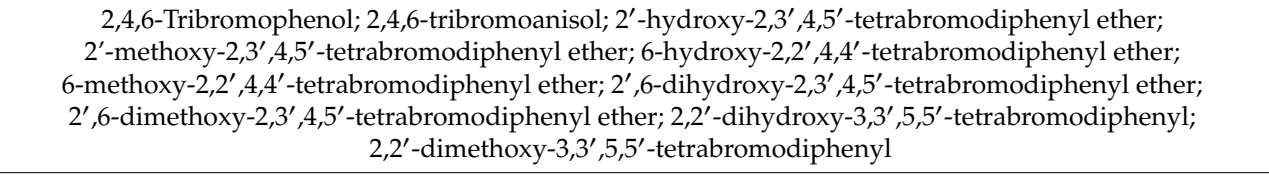 & [122] \\
\hline $\begin{array}{l}\text { Dasycladus vermicularis } \\
\text { MeOH } \\
\text { UPLC-MS/MS }\end{array}$ & 4-(Sulfooxy)phenylacetic acid; 4-(sulfooxy)benzoic acid & [133] \\
\hline \multicolumn{3}{|c|}{ Red seaweeds } \\
\hline $\begin{array}{c}\text { Acanthophora specifera, Ceratodictyon spongiosum, Gracilaria edulis, } \\
\text { Hydropuntia edulis, Halymenia sp., Jania adhaeren, Jania sp., } \\
\text { Kappaphycus alvarezii } \\
\text { MeOH, W } \\
\text { GC-MS-EI-SIM }\end{array}$ & 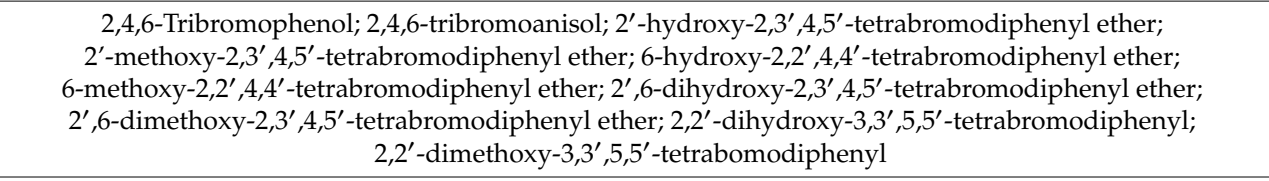 & [122] \\
\hline $\begin{array}{l}\text { Asparagopsis taxiformis } \\
\text { W, MeOH, } \mathrm{CH}_{2} \mathrm{Cl}_{2}, \mathrm{H} \\
\quad \text { GC-MS }\end{array}$ & Bromoform, dibromochloromethane, bromochloroacetic acid, dibromoacetic acid & [100] \\
\hline $\begin{array}{l}\text { Bostrychia radicans } \\
\text { MeOH, H, EtOAc } \\
\text { GC-MS, NMR }\end{array}$ & $\begin{array}{l}\text { N,4-dihydroxy-N-(2'-hydroxyethyl)-benzamide; N,4-dihydroxy-N-(2'-hydroxyethyl)-benzeneacetamide; } \\
\text { methyl 4-hydroxymandelate; methyl 2-hydroxy-3-(4-hydroxyphenyl)-propanoate }\end{array}$ & [134] \\
\hline $\begin{array}{l}\text { C. tenuicorne } \\
\mathrm{H}+\mathrm{DEt}+2-\mathrm{P} \\
\text { GC-MS, ECNI }\end{array}$ & Phenols, hydroxylated, and methoxylated penta- and hexabrominated diphenyl ethers & [135] \\
\hline $\begin{array}{l}\text { C. tenuicorne } \\
\text { H + DEt + 2-P } \\
\text { GC-MS, ECNI }\end{array}$ & $\begin{array}{l}\text { Hydroxylated polybrominated diphenyl ethers } \\
2^{\prime} \text {-hydroxy-2,3',4,5'-tetrabromodiphenyl ether; } 6 \text {-hydroxy-2,2', } 4,4^{\prime} \text {-tetrabromodiphenyl ether }\end{array}$ & [136] \\
\hline $\begin{array}{c}\text { Laurencia nipponica, Odonthalia corymbifera, Polysiphonia morrowii } \\
\text { A, W, MeOH } \\
\text { LC-MS, NMR }\end{array}$ & $\begin{array}{l}\text { 3,5-Dibromo-4-hydroxybenzaldehyde; 3-bromo-4,5-dihydroxybenzyl ether; 3-bromo-4,5-dihydroxybenzyl } \\
\text { alcohol; 5-((2,3-dibromo-4,5-dihydroxybenzyloxy)methyl)-3,4-dibromobenzene-1,2-diol; } \\
\text { 5-(2-bromo-3,4-dihydroxy-6-(hydroxymethyl) benzyl)-3,4-dibromobenzene-1,2-diol }\end{array}$ & [137] \\
\hline
\end{tabular}


Table 3. Cont.

\begin{tabular}{|c|c|c|}
\hline $\begin{array}{l}\text { Seaweed } \\
\text { Extraction } \\
\text { Chemical Analysis }\end{array}$ & $\begin{array}{l}\text { Compounds } \\
\text { Antioxidant Activity (When Provided) }\end{array}$ & Ref. \\
\hline $\begin{array}{l}\text { O. corymbifera, Neorhodomela aculeata, Symphyocladia latiuscula } \\
\text { A, W, MeOH } \\
\text { LC-MS, NMR }\end{array}$ & $\begin{array}{c}\text { n-Butyl 2,3-dibromo-4,5-dihydroxybenzyl ether; } \\
\text { 3-bromo-4-(2,3-dibromo-4,5-dihydroxybenzyl)-5-methoxymethylpyrocatechol; 2,3-dibromo-4,5- } \\
\text { dihydroxybenzyl alcohol; 2,3-dibromo-4,5-dihydroxybenzyl methyl ether; } \\
\text { bis-(2,3,6-tribromo-4,5-dihydroxybenzyl) ether; 2,3,6-tribromo-4,5-dihydroxybenzyl methyl ether; } \\
\text { 2,2',3,3'-tetrabromo-4,4',5,5'-tetrahydroxydiphenylmethane; } \\
\text { 5-(2-bromo-3,4-dihydroxy-6-(hydroxymethyl)benzyl)-3,4-dibromobenzene- 1,2-diol; } \\
\text { 5-((2,3-dibromo-4,5-dihydroxybenzyloxy)methyl)-3,4-dibromobenzene-1,2-diol }\end{array}$ & {$[138$} \\
\hline $\begin{array}{l}\text { Odonthalia corymbifera } \\
\text { MeOH, EtOAc } \\
\text { NMR }\end{array}$ & Odonthalol, odonthadione & {$[139$} \\
\hline $\begin{array}{l}\text { Polysiphonia decipiens } \\
\text { 3:1 } \mathrm{MeOH}: \mathrm{CH}_{2} \mathrm{Cl}_{2} \\
\quad \mathrm{NMR}\end{array}$ & 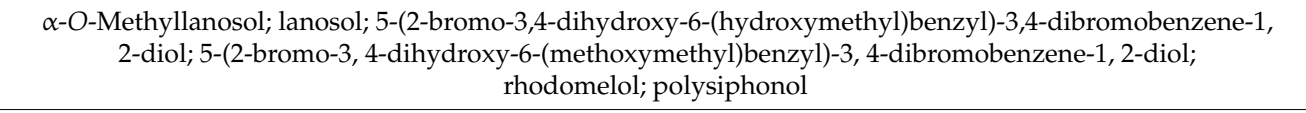 & {$[140]$} \\
\hline $\begin{array}{l}\text { Polysiphonia morrowii } \\
\text { W, } \mathrm{MeOH}_{\mathrm{C}} \mathrm{CH}_{2} \mathrm{Cl}_{2} \\
\text { NMR }\end{array}$ & 3-bromo-4,5-dihydroxybenzyl methyl ether; 3-bromo-4,5-dihydroxybenzaldehyde & {$[141]$} \\
\hline $\begin{array}{l}\text { P. morrowii } \\
\text { W, MeOH } \\
\text { ESI-MS, NMR }\end{array}$ & bis (3-Bromo-4,5-dihydroxybenzyl) ether & {$[142]$} \\
\hline $\begin{array}{l}\text { Rhodomela confervoides } \\
\text { EtOH } \\
\text { NMR }\end{array}$ & $\begin{array}{c}\text { 3-(2,3-Dibromo-4,5-dihydroxybenzyl) pyrrolidine-2,5-dione; methyl } \\
\text { 4-(2,3-dibromo-4,5-dihydroxybenzylamino)-4-oxobutanoate; } \\
\text { 4-(2,3-dibromo-4,5-dihydroxybenzylamino)-4-oxobutanoic acid; 3-bromo-5-hydroxy-4-methoxybenzamide; } \\
\text { 2-(3-bromo-5-hydroxy-4-methoxyphenyl)acetamide; 3-bromo-4,5-bis(2,3-dibromo-4,5-dihydroxybenzyl) } \\
\text { pyrocatechol; methyl 1-(2-(2,3-dibromo-4,5-dihydroxybenzyl)-3-bromo-4,5- } \\
\text { dihydroxybenzyl)-5-oxopyrrolidine-2-carboxylate; } \\
\text { 5-((2,3-dibromo-4,5-dihydroxybenzyloxy)methyl)-3,4-dibromobenzene-1,2-diol; } \\
\text { 5-(2-bromo-3,4-dihydroxy-6-(hydroxymethyl)benzyl)-3,4-dibromobenzene-1,2-diol; } \\
\text { 5-(2-bromo-3,4-dihydroxy-6-(methoxymethyl) benzyl)-3,4-dibromobenzene-1,2-diol; } \\
\text { 5-(2-bromo-6-(ethoxymethyl)-3,4-dihydroxybenzyl)-3,4-dibromobenzene-1,2-diol; } \\
\text { 5-(2,3-dibromo-4,5-dihydroxybenzyl)- 3,4-dibromobenzene-1,2-diol; } \\
\text { 1-(2,3-dibromo-4,5-dihydroxybenzyl)-5-oxopyrrolidine-2-carboxylic acid; methyl } \\
\text { 1-(2,3-dibromo-4,5-dihydroxybenzyl)-5-oxopyrrolidine-2-carboxylate } \\
\text { EC } 50, \text { DPPH = 5.2-23.6 Hmol/L; ABTS = 2.1-3.6 mmol TE/L }\end{array}$ & {$[143$} \\
\hline $\begin{array}{l}\text { Symphyocladia latiuscula } \\
\text { EtOH } \\
\text { NMR }\end{array}$ & $\begin{array}{l}\text { 2,3-Dibromo-4,5-dihydroxybenzyl methyl ether, 3,5-dibromo-4-hydroxybenzoic acid; } \\
\text { 2,3,6-tribromo-4,5-dihydroxymethylbenzene; 2,3,6-tribromo-4,5-dihydroxybenzaldehyde; } \\
\text { 2,3,6-tribromo-4,5-dihydroxybenzyl methyl ether; bis(2,3,6-tribromo-4,5-dihydroxyphenyl)methane; } \\
\text { 1,2-bis(2,3,6-tribromo-4,5-dihydroxyphenyl)-ethane; 1-(2,3,6-tribromo-4,5-dihydroxybenzyl)-pyrrolidin-2-one }\end{array}$ & {$[144]$} \\
\hline
\end{tabular}


Table 3. Cont.

\begin{tabular}{|c|c|c|}
\hline $\begin{array}{c}\text { Seaweed } \\
\text { Extraction } \\
\text { Chemical Analysis }\end{array}$ & $\begin{array}{l}\text { Compounds } \\
\text { Antioxidant Activity (When Provided) }\end{array}$ & Ref. \\
\hline $\begin{array}{l}\text { S. latiuscula } \\
\text { EtOH, EtOAc, W } \\
\text { HRMS, NMR, MS }\end{array}$ & $\begin{array}{c}\text { 1-[2,5-dibromo-3,4-dihydroxy-6-(2,3,6-tribromo-4,5-dihydroxybenzyl)benzyl]pyrrolidin-2-one; methyl } \\
\text { 4-\{(2,3,6-tribromo-4,5-dihydroxybenzyl)[(2,3,6-tribromo-4,5-dihydroxybenzyl)carbamoyl] amino\}butanoate; } \\
\text { methyl 4-\{(2,5-dibromo-3,4-dihydroxybenzyl)[(2,3,6-tribromo-4,5-dihydroxybenzyl)carbamoyl]amino\} } \\
\text { butanoate; } 2,5 \text {-dibromo-3,4-dihydroxy-6-(2,3,6-tribromo-4,5-dihydroxybenzyl)benzyl methyl ether } \\
\mathrm{EC} 50, \mathrm{DPH}=14.5,20.5 \mu \mathrm{g} / \mathrm{L}\end{array}$ & {$[145,146]$} \\
\hline $\begin{array}{l}\text { S. latiuscula } \\
\text { EtOH, EtOAc, W } \\
\text { ESIMS, NMR }\end{array}$ & Bromocatechol conjugates (symphyocladins) & {$[147,148]$} \\
\hline $\begin{array}{l}\text { S. latiuscula } \\
\mathrm{MeOH}, \mathrm{CH}_{2} \mathrm{Cl}_{2} \text {, EtOAc, BuOH, W } \\
\text { ESIMS, NMR }\end{array}$ & $\begin{array}{l}\text { 2,3,6-tribromo-4,5-dihydroxybenzyl alcohol; 2,3,6-tribromo-4,5-dihydroxybenzyl methyl ether; } \\
\text { bis-(2,3,6-tribromo-4,5-dihydroxybenzyl) ether }\end{array}$ & [149] \\
\hline $\begin{array}{l}\text { Vertebrata lanosa } \\
\text { MeOH, EtOAc } \\
\text { ESIMS, NMR }\end{array}$ & 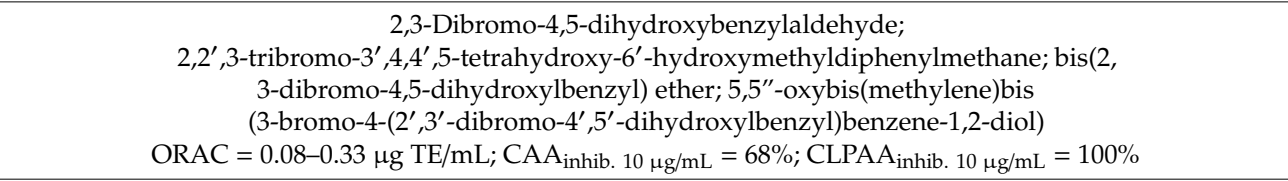 & [95] \\
\hline V. lanosa & $\begin{array}{l}\text { Methylrhodomelol; lanosol; lanosol methyl ether; } \\
\text { 2-amino-5-(3-(2,3-dibromo-4,5-dihydroxybenzyl)ureido)pentanoic acid; } \\
\text { 3-bromo-4-(2,3-dibromo-4,5-dihydroxybenzyl)-5-methoxymethylpyrocatechol; } \\
\text { 5-((2,3-dibromo-4,5-dihydroxybenzyloxy)methyl)-3,4-dibromobenzene-1,2-diol; } \\
\text { 2,2',3,3'-tetrabromo-4,4',5,5'-tetrahydroxydiphenylmethane }\end{array}$ & [150] \\
\hline
\end{tabular}


Kirke et al. [118] reported that low molecular weight phlorotannin fractions $(<3 \mathrm{kDa})$ from F. vesiculosus in powder form remained stable under storage for 10 weeks, when exposed to temperature and oxygen. Although, when suspended in an aqueous matrix, this fraction underwent oxidation when exposed to atmospheric oxygen and $50{ }^{\circ} \mathrm{C}$, and both the DPPH radical scavenging activity and the content of phlorotannins with 6-16 PGUs decreased.

Since other compounds found in the crude seaweed extracts could be responsible for the biological activities, the correlation between phenolic content and antioxidant properties was not always found in seaweed extracts. These relationships should also consider the type of activity assayed since some of them share the same mechanisms [151]. Furthermore, not only the phenolic content is determinant, but also their structure. In brown seaweeds, the classical correlation of phenolic content and radical scavenging has been established with the antiradical properties and molecular weight. Phlorotannin-enriched fractions from water and aqueous ethanolic extracts of A. nodosum and Pelvetia canaliculata contain predominantly larger phlorotannins (DP 6-13) compared to F. spiralis (DP 4-6) [25]. The 3.5-100 kDa and/or $>100 \mathrm{kDa}$ fractions from the cold water and aqueous ethanolic extracts showed higher phenolic content, radical scavenging abilities and ferric reducing antioxidant power (FRAP) than the $<3.5 \mathrm{kDa}$, which could enhance their activity after a reverse-phase flash chromatography fractionation [152]. In a study on F. vesiculosus, Bogolitsyn et al. [22] concluded that the highest radical scavenging activity was observed for average molecular weights from 8 to $18 \mathrm{kDa}$ and the activity decreased with increasing molecular weight from 18 to $49 \mathrm{kDa}$. This effect has been ascribed to the formation of intramolecular and intermolecular hydrogen bonds between hydroxyl groups, causing conformational changes in phlorotannin molecules and, therefore, mutual shielding and a decrease in the availability of active centers. Ascophylllum nodosum purified oligophenolic fraction was more active than the crude fraction as ABTS scavengers, and the fraction containing phenolic compounds with a MW $\geq 50 \mathrm{kDa}$ was the most active and showed higher correlation with the content of phenolic compounds [132]. Whereas the radical scavenging activity and reducing power showed correlation, particularly in brown seaweeds, the chelating properties did not, and were higher in green seaweed extracts, because the major activity could come from the saccharidic fraction [13]. The FRAP activity displayed a stronger correlation with the phlorotannin content than the radical scavenging capacity, as well as the phenolic content, molecular weight and structural arrangement [4]. However, other authors did not find any significant correlation between the total phenolic content of the extracts and the inhibition of red blood cell hemolysis and lipid peroxidation [153], or the antioxidant activity (DPPH and $\beta$-carotene bleaching assays) [154].

\subsubsection{Seagrasses}

Compared to algae, seagrasses are scarcely exploited [11,33]. The worldwide distributed Zostera genus produces large amounts of leaf material. This is not utilized, representing an abundant waste which could be proposed to recover valuable compounds and therefore compensate the costs of cleaning beaches and shorelines used for recreational purposes [10].

Seagrasses are a rich source of (poly)phenolics, including simple and sulfated phenolic acids, such as zosteric acid, and condensed tannins [33,83]. Rosmarinic acid and caffeic acid $(0.4-19.2 \mathrm{mg} / \mathrm{g})$ were the major phenolic components in leaves and roots-rhizomes of eelgrass (Zostera marina L.), and higher concentrations have been found during spring in the younger leaves and roots-rhizomes $[9,78]$. Rosmarinic acid was also reported as an active phenolic in the methanolic extracts from detritus of Z. noltii and Z. marina (2.2-18.0 and 1.3-11.2 mg/g, respectively) [10]. Extraction yields, seasonally dependent for the two species, vary in the range of $9.3-19.7 \%(\mathrm{~g} / \mathrm{g} \mathrm{dw})$ for $Z$. noltii, and $9.6-31 \%$ for Z. marina; near $85 \%$ of the rosmarinic acid was recovered from the crude methanolic extract using ethyl acetate [10]. Chicoric acid was the major compound in Ruppia sp, with $30 \mathrm{mg} / \mathrm{g}$; twice the total flavonoid content [81]. High concentrations of phenolics in methanolic Zostera extracts correspond to higher growth inhibition of the toxic red tide dinoflagellate A. catenella [23]. In sc- $\mathrm{CO}_{2}$ extracts with ethanol or methanol cosolvents, the phenolic content and radical scavenging capacity 
correlated well with the cytotoxicity on tumoral cell lines; this high activity might be due to the high content of phenylpropanoids [155]. The supercritical $\mathrm{CO}_{2}$ extraction of phenolic compounds from Zostera marina residues using $20 \%$ ethanol as co-solvent enhanced the solubilization of polar compounds (chicoric, p-coumaric, rosmarinic, benzoic, ferulic and caffeic) $[29,155]$, reaching phenolic contents comparable to those found in the ethanolic and methanolic Soxhlet extracts; the DPPH radical-scavenging activities were also similar.

\subsubsection{Sponges}

Despite being a rich source of highly bioactive compounds [93], there are few studies in the literature regarding the extraction and identification of polyphenols in sponges. Methanol and dichloromethane were normally used for extraction, while new phenolic compounds have been identified using HRAPCIMS, HRESIMS and NMR. Bisabolenes are particularly interesting polyphenolic compounds found in sponges. These phenolics are characterized by a C-7 absolute stereochemistry. All sponge bisabolenes possess a unique $7 \mathrm{~S}$ configuration, while other marine and terrestrial bisabolenes possess a 7R configuration [91]. (S)-(+)-curcuphenol, a member of this family commonly found in sponges, presents several biological activities [91].

\section{Bioactive Properties of Marine Phenolics}

Epidemiological, clinical and nutritional studies strongly support the evidence that dietary polyphenols play important roles in human health. Their regular consumption has been associated with a reduced risk of different chronic diseases, including cardiovascular diseases (CVDs), cancer and neurodegenerative disorders [156]. Marine polyphenols have also attracted much attention because, similar to other polyphenols, they are bioactive compounds with potential health benefits in numerous human diseases due to their enzyme inhibitory effect and antimicrobial, antiviral, anticancer, antidiabetic, antioxidant, or anti-inflammatory activities; however, most of the findings are based on in vitro assays and animal testing on rodents.

Studies demonstrating the multi-targeted protective effect of marine phenolics, focused on the most prevalent diseases such as type 2 diabetes mellitus, obesity, metabolic syndrome, Alzheimer's disease and cancer, are included in this section. In addition, the influence of marine phenolics on gut human microbiota and other infectious have been also addressed (Tables 4-10).

\subsection{Type 2 Diabetes Mellitus}

Type 2 diabetes mellitus (T2DM) is one of the most common non-communicable diseases in the world, which can be attributed to hyperglycemia characterized by a high glucose concentration circulating in the blood, and has a marked impact on the quality of life [157]. This disease leads to higher risk of premature death and is associated with several health problems such as vision loss, kidney failure, leg amputation, nerve damage, heart attack and stroke [158]. Due to its chronic nature, T2DM is also associated with several comorbidities such as metabolic syndrome (MetS), overweight and obesity, hypertension, non-alcoholic hepatic steatosis, coronary disease, and neuropathy, among others [159].

Phlorotannins of edible seaweeds are involved in various antidiabetic mechanisms: inhibition of starch-digesting enzymes $\alpha$-amylase and $\alpha$-glucosidase, protein tyrosine phosphatase 1B (PTP1B) enzyme inhibition, modulation of glucose-induced oxidative stress and reduction in glucose levels and lipid peroxidation, among others $[160,161]$. There are a few recent reviews that summarize the huge number of in vitro studies along with minor number of in vivo studies focused in evaluating the antidiabetic activity of polyphenols $[35,36,160,162]$ or bioactive components of seaweeds $[161,163]$. Key in vitro studies along with the recent in vivo studies about antidiabetic activity of marine polyphenols are detailed below (Table 4).

Alpha-amylase, located in the pancreas, and $\alpha$-glucosidase, at the brush border of intestinal cells, are two key enzymes involved in carbohydrate metabolism [164]. These enzymes break down carbohydrates into monosaccharides that are absorbed into the bloodstream, resulting in a rise in 
blood glucose following a meal. Oral glucosidase inhibitor drugs are the common clinical treatment for T2DM; however, long-term use can result in side effects such as renal tumors and hepatic injury [164]. Hence, looking for alternative natural products with no side effects is an active research area. Most brown seaweeds belonging to the genus Ecklonia and family Lessoniaceae have been reported to exhibit antidiabetic activities [160]. Five isolated phlorotannins from E. cava, fucodiphloroethol G, dieckol, 6,6'-bieckol, 7-phloroeckol, phlorofucofuroeckol-A, have shown a marked $\alpha$-glucosidase inhibition with $19.5 \mu \mathrm{M}, 10.8 \mu \mathrm{M}, 22.2 \mu \mathrm{M}, 49.5 \mu \mathrm{M}$ and $19.7 \mu \mathrm{M}$, respectively, as well as some $\alpha$-amylase inhibitory effect with $\mathrm{IC}_{50}$ values of $>500 \mu \mathrm{M}, 125 \mu \mathrm{M},>500 \mu \mathrm{M}, 250 \mu \mathrm{M}$ and $>500 \mu \mathrm{M}$, respectively [165]. Phlorotannins extracted from A. nodosum [166,167], Alaria marginata and Fucus distichus [168] are also able to inhibit $\alpha$-amylase and $\alpha$-glucosidase, while those of F. vesiculosus [160] and L. trabeculate [103] inhibit $\alpha$-glucosidase activity, and L. trabeculate [103] inhibits lipase activity (Table 4). Generally, seaweed extracts and isolated compounds exhibited more inhibitory potency towards $\alpha$-glucosidase compared to $\alpha$-amylase (see $\mathrm{IC}_{50}$ values in Table 4 ), which is desirable since high inhibition of $\alpha$-amylase activity has been suggested to cause abnormal fermentation of undigested carbohydrates by the colonic microbiota [169]. This promising inhibitory activity towards the enzymes involved in the digestion of carbohydrates has led to the development of polyphenol-rich extracts from seaweeds as alternative drugs to treat T2DM. Catarino et al. [120] obtained crude extracts and semi-purified phlorotannins from F. vesiculosus containing fucols, fucophlorethols, fuhalols and several other phlorotannin derivatives, tentatively identified as fucofurodiphlorethol, fucofurotriphlorethol and fucofuropentaphlorethol. These extracts showed the potential to control the activities of $\alpha$-amylase, pancreatic lipase, and particularly $\alpha$-glucosidase, for which a greater inhibitory effect was observed compared to the pharmaceutical drug acarbose $\left(\mathrm{IC}_{50} \sim 4.5-0.82 \mu \mathrm{g} / \mathrm{mL}\right.$ against $206 \mu \mathrm{g} / \mathrm{mL}$, respectively). Park et al. [170] isolated minor phlorotannin derivatives from E. cava that effectively inhibited the activity of $\alpha$-glucosidase, with $\mathrm{IC}_{50}$ values ranging from 2.3 to $59.8 \mu \mathrm{M}$; they obtained the kinetic parameters of the receptor-ligand binding by a fluorescence-quenching study. In the same line, Lopes et al. [8] isolated phlorotannins from four edible Fucus species (F. guiryi, F. serratus, F. spiralis and F. vesiculosus). These were chemically characterized using mass spectrometry-based techniques (HPLC-DAD-ESI/MS and UPLC-ESI-QTOF/MS). The isolated phlorotannins showed inhibitory activity against $\alpha$-amylase and $\alpha$-glucosidase, being particularly important in the activity of the latter, with $\mathrm{IC}_{50}$ values significantly lower (between 2.48 and $4.77 \mu \mathrm{g} / \mathrm{mL}$ ) than those obtained for the pharmacological inhibitors acarbose and miglitol (between 56.43 and $1835.37 \mu \mathrm{g} / \mathrm{mL}$ ). F. guiryi and F. serratus were the most active of the tested Fucus species. In addition, xanthine oxidase activity, an enzymatic system usually overexpressed in diabetes and responsible for producing deleterious free radicals, was also inhibited, related with the antioxidant activity associated to phlorotannins [8].

Protein tyrosine phosphatase 1B (PTP1B) is a major negative regulator of insulin signaling and is localized on the cytoplasmic surface of the endoplasmic reticulum in hepatic, muscular and adipose tissues. Due to its ubiquity in the insulin-targeted tissues and its role in insulin resistance development [142], inhibition of PTP1B activity would be a target for the treatment of T2DM and obesity. Ezzat et al. [171] reviewed the in vitro studies focused on evaluating the inhibitory activity of PTP1B marine polyphenols. Xu et al. [172] studied the inhibitory activity of a marine-derived bromophenol compound (3,4-dibromo-5-(2-bromo-3,4-dihydroxy-6-(ethoxymethyl)benzyl)benzene-1,2-diol) isolated from the red alga Rhodomela confervoides in insulin-resistant $\mathrm{C} 2 \mathrm{C} 12$ myotubes. This bromophenol has the ability to inhibit PTP1B activity ( IC $_{50} 0.84 \mu \mathrm{M}$ ), permeate into cells and bind to the catalytic domain of PTP1B in vitro, activate insulin signaling and potentiate insulin sensitivity in $\mathrm{C} 2 \mathrm{C} 12$ myotubes as well as enhance glucose uptake. Similarly, 3-bromo-4,5-bis(2,3-dibromo-4,5-dihydroxybenzyl)-1,2-benzenediol isolated from the red alga Rhodomela confervoides was able to activate insulin signaling and prevent palmitate-induced insulin resistance by intrinsic PTP1B inhibition ( $\left.\mathrm{IC}_{50} 2.0 \mu \mathrm{M}\right)$. Moreover, this compound also activated the fatty acid oxidation signaling in palmitate-exposed C2C12 myotubes [173]. 
Glycated insulin is commonly found in T2DM patients and is less effective in controlling glucose homeostasis and stimulating glucose uptake than non-glycated insulin [174]. Non-enzymatic protein glycation is an irreversible modification between reducing sugars and primary amino groups and leads to the production of advanced glycation end-products (AGEs) [175], whose accumulation causes various diabetic complications such as nephropathy, retinopathy and atherosclerosis as well as stimulates the development of neurodegenerative diseases such as Alzheimer's disease (AD) [176]. The inhibition of AGEs formation is another approach being explored in managing hyperglycemia using seaweeds. Crude phlorotannins contained in the Japanese Lessoniaceae exhibited an inhibitory effect on the formation of fluorescence bound AGEs ( $\mathrm{IC}_{50} 0.43-0.53 \mathrm{mg} / \mathrm{mL}$ ), and among the purified phlorotannins (phlorofucofuroeckol-A, eckol, phloroglucinol, fucofuroeckol A, dieckol and 8,8'-bieckol), phlorofucofuroeckol A showed the highest inhibitory activity ( $\mathrm{IC}_{50} 4.1-4.8 \times 10^{2} \mu \mathrm{M}$ ) against fluorescent AGEs formation, being about 15 times more active than the reference drug aminoguanidine hydrochloride [177]. Further studies carried out with methanolic extracts from brown algae Padina pavonica, Sargassum polycystum, and Turbinaria ornata, rich in phlorotannins, inhibited the glucose-induced protein glycation and formation of protein-bound fluorescent AGEs ( $\mathrm{IC}_{50} 15.16 \mu \mathrm{g} / \mathrm{mL}$, $35.25 \mu \mathrm{g} / \mathrm{mL}$ and $22.7 \mu \mathrm{g} / \mathrm{mL}$, respectively). Furthermore, brown algal extracts containing phlorotannins exhibited protective effects against AGEs formation in Caenorhabditis elegans (a species of nematode) with induced hyperglycemia [178]. From five phlorotannins isolated from E. stolonifera, only phlorofucofuroeckol-A inhibited, in a dose-dependent form, the induced non-enzymatic insulin glycation of D-ribose and D-glucose ( $\mathrm{IC}_{50} 29.50 \mu \mathrm{M}$ and $43.55 \mu \mathrm{M}$, respectively) [179]. These authors used computational analysis to find that phlorofucofuroeckol-A interacts with the Phe1 in insulin chain-B, blocking D-glucose access to the glycation site of insulin.

The need to secrete increasing amounts of insulin to compensate for progressive insulin resistance and the hyperglycemia-induced oxidative stress lead to an eventual deterioration of pancreatic $\beta$-cells [180]. Lee et al. [181] confirmed the protective effect of octaphlorethol A, a novel phenolic compound isolated from Ishige foliacea, against streptozotocin (STZ)-induced pancreatic $\beta$-cell damage investigated in a rat insulinoma cell line (RINm5F pancreatic $\beta$-cells). Thus, octaphlorethol A reduced the intracellular reactive oxygen species (ROS) and generation of thiobarbituric acid reactive substances (TBARs), extensively produced by STZ-treated pancreatic $\beta$-cells. The oxidative stress involved in diabetes-associated pathological damages reduces antioxidant enzyme activities (catalase (CAT), superoxide dismutase (SOD), and glutathione peroxidase (GPx)), and octaphlorethol A treatment increased the enzyme activity due to its antioxidant potency. The phlorotannins isolated from E. cava, 6,6-bieckol, phloroeckol, dieckol and phlorofucofuroeckol inhibited high glucose-induced ROS and cell death in zebrafish. Particularly, the antioxidant activity of dieckol significantly reduced heart rates, ROS, nitric oxide (NO) and lipid peroxidation generation in high glucose-induced oxidative stress. Dieckol also reduced overexpression of inducible nitric oxide synthase (iNOS) and cyclooxygenase-2 (COX-2) [182]. A recent study addressed the efficacy of an extract of the red seaweed Polysiphinia japonica on preserving cell viability and glucose-induced insulin secretion in a pancreatic $\beta$-cell line, Ins-1, treated with palmitate [183]. However, the tested extract contained, in addition to polyphenols, other components such as carbohydrates, lipid and proteins; hence, the described bioactivities may not be due only to polyphenols.

Glucose uptake and disposal mainly occurs in the skeletal muscle, playing an important role in the energy balance regulation [184]; marine polyphenols are also involved in this mechanism. Lee et al. [185] confirmed that octaphlorethol A from Ishige foliacea increased glucose uptake in skeletal muscle cells (differentiated L6 rat myoblast). Furthermore, this compound increased glucose transporter 4 (Glut4) translocation to the plasma membrane, in a process depending on the protein kinase B (Akt) and AMP-activated protein kinase (AMPK) activation, a therapeutic target for treatment of hyperglycemia, which is associated with insulin resistance [186]. 
Table 4. Effect of marine phenolics in the prevention of type 2 diabetes mellitus (T2DM).

\begin{tabular}{|c|c|c|c|}
\hline Compounds/Marine Source & Test Model & Outcome & Ref. \\
\hline $\begin{array}{l}\text { Five isolated phlorotannins from E. cava (fucodiphloroethol G, dieckol, 6,6'-bieckol, } \\
\text { 7-phloroeckol, phlorofucofuroeckol-A) }\end{array}$ & In vitro assay: $\alpha$-glucosidase and $\alpha$-amylase inhibitory activity & $\begin{array}{c}\text { Inhibition of } \alpha \text {-glucosidase }\left(\mathrm{IC}_{50} \text { values ranged from } 10.8 \mu \mathrm{M} \text { for }\right. \\
\text { dieckol to } 49.5 \mu \mathrm{M} \text { for } 7 \text {-phloroeckol) } \\
\text { and } \alpha \text {-amylase (IC } \mathrm{I}_{50} \text { values ranged from } 125 \mu \mathrm{M} \text { for dieckol to } \\
<500 \mu \mathrm{M} \text { for the rest of compounds, except } 7 \text {-phloroeckol with a } \\
\text { value of } 250 \mu \mathrm{M} \text { ) activities }\end{array}$ & [165] \\
\hline Methanolic extract isolated from A. nodosum rich in phlorotannins & In vitro assay: $\alpha$-glucosidase and $\alpha$-amylase inhibitory activity & $\begin{array}{l}\text { Inhibition of } \alpha \text { - glucosidase }\left(\mathrm{IC}_{50} \sim 20 \mu \mathrm{\mu g} / \mathrm{mL} \mathrm{GAE}\right) \text { and } \alpha \text {-amylase } \\
\text { (IC } \mathrm{IC}_{50} \sim .1 \mu \mathrm{gg} / \mathrm{mL} \mathrm{GAE} \text { ) activities }\end{array}$ & [166] \\
\hline $\begin{array}{l}\text { Cold aqueous and ethanolic extracts of A. nodosum and F. vesiculosus rich } \\
\text { in phlorotannins }\end{array}$ & In vitro assay: $\alpha$-glucosidase and $\alpha$-amylase inhibitory activity & $\begin{array}{l}\text { Inhibition of } \alpha \text { - glucosidase (IC } \mathrm{IC}_{50} \sim 0.32-0.50 \mu \mathrm{\mu g} / \mathrm{mL} \mathrm{GAE} \text { for } \\
\text { F. vesiculosus) and } \alpha \text {-amylase (IC } 5044.7-53.6 \mu \mathrm{g} / \mathrm{mL} \text { GAE for } \\
\text { A. nodosum) activities }\end{array}$ & [167] \\
\hline Methanolic extract from Alaria marginata and Fucus distichus rich in phlorotannins & In vitro assay: $\alpha$-glucosidase and $\alpha$-amylase inhibitory activity & $\begin{array}{l}\text { Inhibition of } \alpha \text { - glucosidase }\left(\mathrm{IC}_{50} \sim 0.89 \mu \mathrm{g} / \mathrm{mL}\right) \text { and } \alpha \text {-amylase } \\
\left.\text { (IC } \mathrm{C}_{50} \sim 13.9 \mu \mathrm{g} / \mathrm{mL}\right) \text { activities }\end{array}$ & [168] \\
\hline Polyphenol-rich extracts from $L$. trabeculate & In vitro assay: $\alpha$-glucosidase and lipase activity & Inhibition of $\alpha$-glucosidase and lipase activities $\left(\mathrm{IC}_{50}<0.25 \mathrm{mg} / \mathrm{mL}\right)$ & [103] \\
\hline $\begin{array}{l}\text { Crude extract and semi-purified phlorotannins from } F \text {. vesiculosus composed by fucols, } \\
\text { fucophlorethols, fuhalols and several other phlorotannin derivatives }\end{array}$ & $\begin{array}{l}\text { In vitro assay: } \alpha \text {-glucosidase, } \alpha \text {-amylase and pancreatic lipase } \\
\text { inhibitory activity }\end{array}$ & $\begin{array}{l}\text { Inhibition of } \alpha \text {-amylase }\left(\mathrm{IC}_{50} \sim 28.8-2.8 \mu \mathrm{g} / \mathrm{mL}\right), \alpha \text {-glucosidase } \\
\left(\mathrm{IC} \mathrm{I}_{50} \sim .5-0.82 \mu \mathrm{g} / \mathrm{mL}\right) \text { and pancreatic lipase } \\
\left(\mathrm{II} \mathrm{C}_{50} \sim 5.9-19.0 \mu \mathrm{g} / \mathrm{mL}\right) \text { activities }\end{array}$ & [120] \\
\hline Phlorotannin derivatives from E. cava & In vitro assay: $\alpha$-glucosidase inhibitory activity & $\begin{array}{l}\text { Inhibition of } \alpha \text {-glucosidase activity }\left(\mathrm{IC}_{55} \sim 2.3-59.8 \mu \mathrm{M}\right) \\
\text { Kinetic parameters of receptor-ligand binding }\end{array}$ & [163] \\
\hline $\begin{array}{l}\text { Phlorotannin-targeted extracts from four edible Fucus species (F. guiryi, F. serratus, } \\
\text { F. spiralis and F. vesiculosus) }\end{array}$ & In vitro assay: $\alpha$-glucosidase and $\alpha$-amylase inhibitory activity & $\begin{array}{c}\text { Inhibition of } \alpha \text {-glucosidase }\left(\mathrm{IC}_{50} \sim 2.48-4.77 \mu \mathrm{g} / \mathrm{mL}\right), \alpha \text {-amylase } \\
\left.\text { (IC } \mathrm{I}_{50} \sim 23.31-253.31 \mu \mathrm{gg} / \mathrm{mL}\right) \text { and xanthine oxidase } \\
\left(\mathrm{IC}_{50} \sim 157.66-800.08 \mu \mathrm{gg} / \mathrm{mL} \text { ) activities }\right.\end{array}$ & [8] \\
\hline $\begin{array}{l}\text { Marine-derived bromophenol compound } \\
\text { (3,4-dibromo-5-(2-bromo-3,4-dihydroxy-6-(ethoxymethyl)benzyl)benzene-1,2-diol) } \\
\text { isolated from Rhodomela confervoides }\end{array}$ & $\begin{array}{l}\text { In vitro: insulin resistant } \mathrm{C} 2 \mathrm{C} 12 \text { cells treated with bromophenol } \\
\qquad(0.1-0.5 \mu \mathrm{M} \text { for phenol) }\end{array}$ & $\begin{array}{l}\text { Inhibition of PTP1B activity }\left(\mathrm{I} \mathrm{IC}_{50} \sim 0.84 \mu \mathrm{M}\right) \\
\text { Activation of insulin signaling and potentiate insulin sensitivity }\end{array}$ & [172] \\
\hline $\begin{array}{l}\text { 3-Bromo-4,5-bis(2,3-dibromo-4,5-dihydroxybenzyl)-1,2-benzenediol isolated from the } \\
\text { red alga Rhodomela confervoides }\end{array}$ & $\begin{array}{l}\text { In vitro: palmitate-induced insulin resistance in } \mathrm{C} 2 \mathrm{C} 12 \text { cells treated } \\
\text { with bromophenol }(0.5-2.0 \mu \mathrm{M} \text { for phenol) }\end{array}$ & $\begin{array}{l}\text { Inhibition of PTP1B activity }\left(\mathrm{IC}_{50} \sim 2 \mu \mathrm{M}\right) \\
\text { Activation of insulin signaling and prevent palmitate-induced } \\
\text { insulin resistance }\end{array}$ & [173] \\
\hline $\begin{array}{l}\text { Phlorofucofuroeckol-A, eckol, phloroglucinol, fucofuroeckol A, dieckol and 8,8'-bieckol } \\
\text { isolated and crude phlorotannins from Lessoniaceae }\end{array}$ & In vitro assay: human and bovine serum albumin models & $\begin{array}{l}\text { Inhibition of AGEs formation, crude phlorotannins showed } \\
\mathrm{IC}_{50} \sim 0.43-0.53 \mathrm{mg} / \mathrm{mL} \text {, and among the purified phlorotannins, } \\
\text { phlorofucofuroeckol A was the most active }\left(\mathrm{I}_{50} \sim 4.1-4.8 \mu \mathrm{M}\right)\end{array}$ & [177] \\
\hline Methanolic extract from P. pavonica and Turbinaria ornate rich in phlorotannins & $\begin{array}{l}\text { In vitro assay: BSA-glucose assay } \\
\text { In vivo: Caenorhabditis elegans with induced hyperglycemia }\end{array}$ & $\begin{array}{c}\text { Inhibition of AGEs formation (IC } \mathrm{IC}_{50} \sim 15.16 \mu \mathrm{\mu g} / \mathrm{mL}, 35.25 \mu \mathrm{g} / \mathrm{mL} \text { and } \\
22.7 \mathrm{\mu g} / \mathrm{mL} \text {, respectively) } \\
\text { Inhibition of AGEs formation }\end{array}$ & [178] \\
\hline Phlorofucofuroeckol-A isolated from E. stolonifera & In vitro assay for non-enzymatic insulin glycation & $\begin{array}{l}\text { Inhibition of AGEs formation (IC } \mathrm{C}_{50} 29.50-43.55 \mu \mathrm{M} \text { for D-ribose and } \\
\text { D-glucose-induced insulin glycation, respectively) }\end{array}$ & [179] \\
\hline Octaphlorethol A isolated from Ishige foliacea & $\begin{array}{l}\text { In vitro: STZ-induced pancreatic } \beta \text {-cell damage (RINm5F pancreatic } \\
\beta \text {-cells) }(12.5-50.0 \mu \mathrm{\mu g} / \mathrm{mL} \text { for phenol) }\end{array}$ & $\begin{array}{l}\text { Decreased the death of STZ-treated pancreatic } \beta \text {-cells } \\
\text { Decreased the TBARS and ROS } \\
\text { Increased the activity of antioxidant enzymes }\end{array}$ & [181] \\
\hline 6,6-Bieckol, phloroeckol, dieckol and phlorofucofuroeckol isolated from E. cava & $\begin{array}{l}\text { In vivo: high glucose-stimulated oxidative stress in Zebrafish, } \\
\text { a vertebrate model (10-20 } \mu \mathrm{M} \text { of phenols) }\end{array}$ & $\begin{array}{l}\text { Inhibition of high glucose-induced ROS and cell death } \\
\text { Dieckol reduced the heart rates, ROS, NO and lipid peroxidation } \\
\text { Dieckol reduced the overexpression of iNOS and COX-2 }\end{array}$ & [182] \\
\hline Extract isolated from the red seaweed Polysiphonia japonica & $\begin{array}{l}\text { In vitro: palmitate-induced damage in } \beta \text {-cells (Ins- } 1 \text { cells) } \\
\qquad(1-10 \mu \mathrm{g} / \mathrm{mL} \text { of extract) }\end{array}$ & $\begin{array}{l}\text { Inhibited the palmitate-induced damage in } \beta \text {-cells } \\
\text { Preserved the glucose-induced insulin secretion in } \beta \text {-cells }\end{array}$ & [183] \\
\hline
\end{tabular}


Table 4. Cont.

\begin{tabular}{|c|c|c|c|}
\hline Compounds/Marine Source & Test Model & Outcome & Ref. \\
\hline Octaphlorethol A from Ishige foliacea & In vitro: rat myoblast L6 cells $(6.25-50 \mu \mathrm{M}$ of phenol) & $\begin{array}{l}\text { Increased the glucose uptake } \\
\text { Increased the Glut4 translocation to the plasma membrane, via Akt } \\
\text { and AMPK activation }\end{array}$ & [185] \\
\hline Dieckol isolated from E. cava & $\begin{array}{c}\text { In vivo: STZ-induced diabetic mice (acute, } 100 \mathrm{mg} / \mathrm{kg} \text { bw of dieckol } \\
\text { administered orally) }\end{array}$ & Delayed the absorption of dietary carbohydrates & [187] \\
\hline 2,7"-Phloroglucinol-6,6'-bieckol from E. cava & $\begin{array}{l}\text { In vivo: STZ-induced diabetic mice (acute, } 10 \mathrm{mg} / \mathrm{kg} \text { bw of phenol } \\
\text { administered orally) }\end{array}$ & $\begin{array}{l}\text { Delayed the absorption of dietary carbohydrates } \\
\text { Inhibition of } \alpha \text {-glucosidase and } \alpha \text {-amylase activities (IC } \mathrm{IC}_{50} 23.35 \mu \mathrm{M} \\
\text { and } 6.94 \mu \mathrm{M} \text {, respectively) }\end{array}$ & [188] \\
\hline Polyphenol-rich seaweed extract from F. vesiculosus & In vivo: 38 healthy adults (acute, $500 \mathrm{mg}$ and $2000 \mathrm{mg}$ of phenol) & No change in postprandial blood glucose and insulin levels & [189] \\
\hline Dieckol isolated from brown seaweed E. cava & $\begin{array}{l}\text { In vivo: a T2DM mouse model (C57BL/KsJ-db/db) }(10 \text { and } \\
20 \mathrm{mg} / \mathrm{kg} \text { bw of phenol for } 14 \text { days administered } \\
\text { intraperitoneal injection) }\end{array}$ & $\begin{array}{l}\text { Diminished the fasting blood glucose and insulin levels } \\
\text { Diminished the body weight } \\
\text { Decreased the TBARS } \\
\text { Increased the activity of antioxidant enzymes in liver tissues } \\
\text { Increased the levels of AMPK and Akt phosphorylation in } \\
\text { muscle tissues }\end{array}$ & [190] \\
\hline Polyphenol-rich extracts from brown macroalgae $L$. trabeculata & $\begin{array}{l}\text { In vitro assay: } \alpha \text {-glucosidase and lipase inhibitory activities } \\
\text { In vivo: high-fat diet and STZ-induced diabetic rats } \\
\text { (200 mg/kg/day bw of phenol for } 4 \text { weeks by gavage })\end{array}$ & $\begin{array}{l}\text { Inhibition of } \alpha \text {-glucosidase and lipase activities }\left(\mathrm{IC}_{50}<0.25 \mathrm{mg} / \mathrm{mL}\right) \\
- \\
\text { Diminished the fasting blood glucose and insulin levels } \\
\text { Improved the serum lipid profile } \\
\text { Improved the antioxidant stress parameters }\end{array}$ & [103] \\
\hline Water-ethanolic extract of green macroalgae Enteromorpha prolifera rich in flavonoids & $\begin{array}{l}\text { In vivo: STZ-induced diabetic rats }(150 \mathrm{mg} / \mathrm{kg} / \mathrm{day} \text { bw of phenol for } \\
4 \text { weeks by gavage) }\end{array}$ & $\begin{array}{l}\text { Diminished the fasting blood glucose and improved oral } \\
\text { glucose tolerance } \\
\text { Hypoglycemic effect by increasing IRS1/PI3K/Akt and suppressing } \\
\text { JNK1/2 in liver }\end{array}$ & [191] \\
\hline
\end{tabular}

Dieckol-rich extract of brown algae E. cava $\quad$ In vivo: 8 pre-diabetic adults (1500 $\mathrm{mg}$ per day for 12 weeks) $\quad$ Decreased the postprandial glucose, insulin, and C-peptide levels

GAE: gallic acid equivalents; PTP1B: protein tyrosine phosphatase 1B; AGEs: advanced glycation end-products; ROS: reactive oxygen species; TBARs: thiobarbituric acid reactive

substances; NO: nitric oxide; iNOS: inducible nitric oxide synthase; COX-2: cyclooxygenase-2; Glut4: glucose transporter 4; Akt: protein kinase B; AMPK: AMP-activated protein kinase;

PI3K: phosphoinositide 3-kinase; IRS1: Insulin receptor substrate 1; JNKs: c-Jun N-terminal kinases. 
Since postprandial blood glucose is a stronger predictor of cardiovascular events than fasting blood glucose in T2DM [193], polyphenol-rich extracts from seaweeds have been evaluated for their postprandial effect. After oral administration of soluble starch with dieckol (100 mg/kg bw), isolated from E. cava, a significant reduction in the postprandial blood glucose level in both normal mice and STZ-induced diabetic mice [187] were observed. Likewise, a phlorotannin constituent of E. cava (2,7'"-phloroglucinol-6,6'-bieckol) inhibited $\alpha$-glucosidase and $\alpha$-amylase activities ( IC $_{50}$ values of 23.35 and $6.94 \mu \mathrm{M}$, respectively), which was more effective than that observed with the positive control acarbose ( $\mathrm{IC}_{50}$ values of 130.04 and $165.12 \mu \mathrm{M}$, respectively). In addition, this phlorotannin alleviated postprandial hyperglycemia in diabetic mice treated with $10 \mathrm{mg} / \mathrm{kg}$ bw [188]. A randomized cross-over trial carried out by Murray et al. [189] evaluated the impact of a single dose of a polyphenol-rich seaweed extract from F. vesiculosus on postprandial glycemic control in 38 healthy adults. Neither low (500 mg) nor high (2000 mg) doses of the polyphenol-rich brown seaweed affected the postprandial blood glucose and insulin levels in healthy volunteers.

The in vivo chronic treatment with polyphenol-rich extracts from seaweeds showed an important activity in the attenuation of T2DM. The antidiabetic activity of dieckol isolated from brown seaweed E. cava was evaluated in a T2DM mouse model (C57BL/KsJ-db/db). Dieckol was administrated daily at doses of 10 and $20 \mathrm{mg} / \mathrm{kg}$ bw for 14 days. Results showed a significant reduction in blood glucose and serum levels as well as body weight, when compared to the untreated group [190]. Furthermore, reduced TBARs and increased activity of antioxidant enzymes (SOD, CAT and GPx) in liver tissues, as consequence of the antioxidant potency of phlorotannins, and increased levels of AMPK and Akt phosphorylation in muscle tissues, which play a vital role in the glucose homeostasis, were observed in the dieckol treated group. Another recent study showed the capacity of a polyphenol-rich extracts from the brown macroalgae Lessonia trabeculata to attenuate hyperglycemia in high-fat diet and STZ-induced diabetic C57BL/6J rats treated for 4 weeks (200 mg/kg bw/day). Lower fasting blood glucose and insulin levels, as well as a better serum lipid profile and antioxidant stress parameters compared with the diabetic control group, were observed [103]. Similarly, a water-ethanolic extract of green macroalgae E. prolifera rich in flavonoids showed antidiabetic activity, by improving oral glucose tolerance and insulin sensitivity, decreasing fasting blood glucose levels and protecting kidney and liver from high sucrose-fat diet on STZ-induced diabetic mice treated with $150 \mathrm{mg} / \mathrm{kg}$ bw/day of the assayed extract for 4 weeks. This flavonoid-rich fraction revealed a hypoglycemic effect as confirmed by activation of the IRS1/PI3K/Akt and inhibition of the c-Jun N-terminal kinases (JNK)1/2 insulin pathway in liver [191].

In pre-diabetic human subjects, the efficacy and safety of a dieckol-rich extract from E. cava was evaluated by the development of a double-blind, randomized, placebo-controlled clinical trial. The daily consumption of $1500 \mathrm{mg}$ of the dieckol-rich extract decreased postprandial glucose, insulin, and C-peptide levels after 12 weeks, but there was no significant difference between the supplemented and placebo groups [192].

Strong evidence regarding the antidiabetic activity of several marine polyphenols have been obtained (Table 4). They are involved in different and complementary mechanisms (Figure 2), although most of the studies are in vitro or in vivo with animals, not with humans as desirable. 


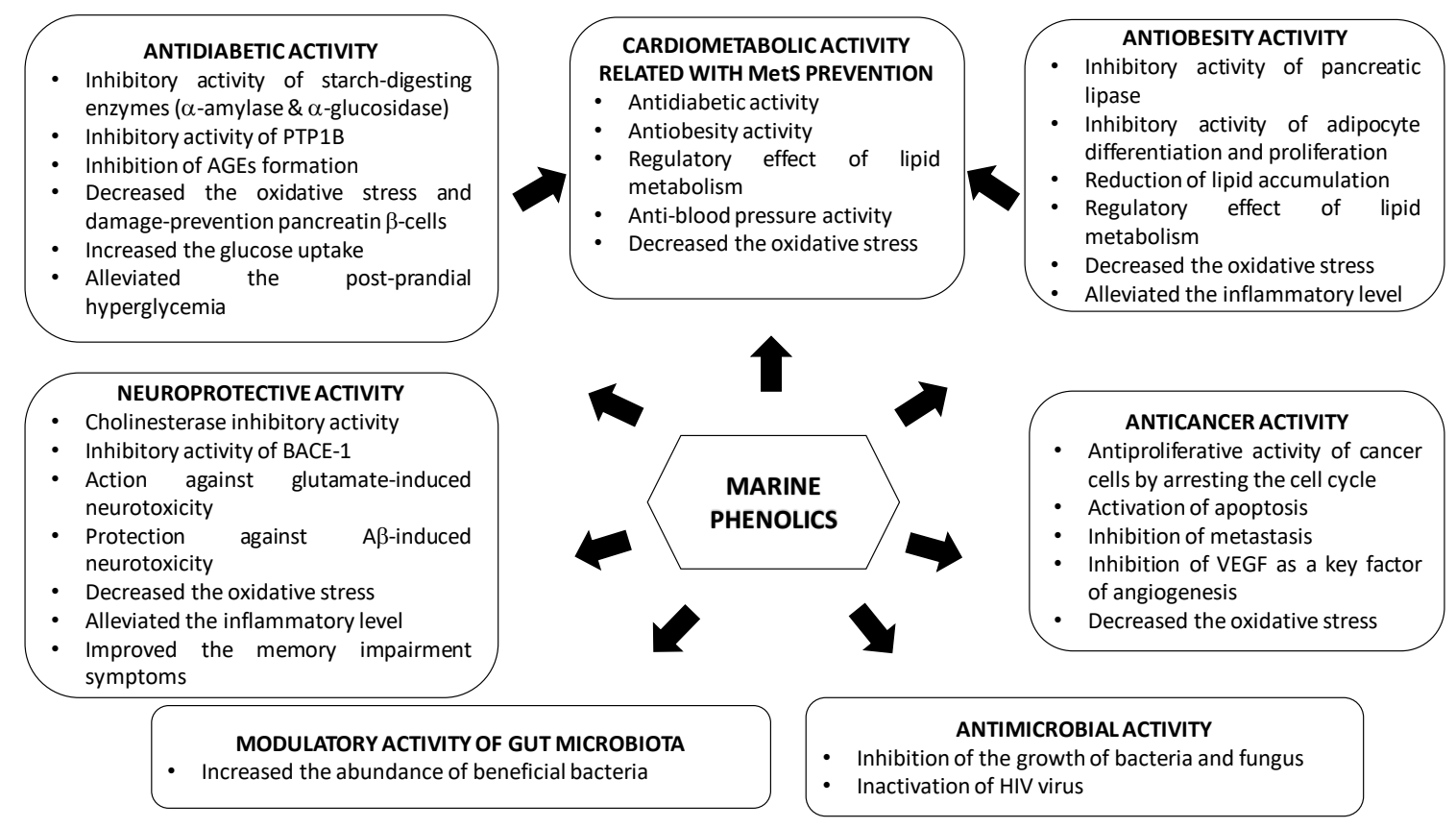

Figure 2. Mechanisms of action of marine phenolics.

\subsection{Obesity}

Obesity-defined as the excessive or abnormal accumulation of body fat in the adipose tissue, energy imbalance, and lipogenesis-results from modern lifestyles characterized by high intakes of fat, sugar, and calories, in addition to poor exercise and physical activity [194]. The molecular mechanism of obesity mediated by cytokines, adiponectin, and leptin has been correlated with increasing inflammation and oxidative stress, and leads to the development of metabolic diseases including certain types of cancer, hyperglycemia, T2DM, high blood pressure, as well as liver, heart, and gallbladder diseases [195-197]. Consequently, researchers have been exploring functional materials of plant origin that contain antioxidants and other properties to combat obesity and its comorbidities, as an alternative to conventional approaches such as surgery and antiobesity drugs.

Pancreatic lipase is a key enzyme for triglyceride absorption in the small intestine, which hydrolyses triglycerides into glycerol and fatty acids. Pancreatic lipase inhibitors hinder fat digestion and absorption and are a potential therapeutic target for the treatment of diet-induced obesity in humans. In an ongoing search for new pancreatic lipase inhibitors from natural sources, polyphenols isolated from seaweeds have repeatedly shown inhibitory activity against this enzyme, such as a methanolic extract of the marine brown algae E. bicyclis. Bioassay-guided isolation of this methanolic extract using a pancreatic lipase inhibitory test led to the identification of six known phlorotannins: eckol, fucofuroeckol A, 7-phloroeckol, dioxindehydroeckol, phlorofucofuroeckol A, and dieckol. Among them, fucofuroeckol and 7-phloroeckol showed the most potent inhibitory effect on pancreatic lipase activity ( $\mathrm{IC}_{50}$ values of 37.2 and $12.7 \mu \mathrm{M}$, respectively) [198]. More recently, Austin et al. [199] evaluated the inhibitory lipase activity of a polyphenol-rich extract from the edible seaweed A. nodosum. This crude extract showed higher inhibitory activity than the known commercial product, Orlistat. Additionally, a phlorotannin-enriched fraction obtained from the crude extract was even more potent than the un-purified extract. Although the purified extract also contained polysaccharides such as alginate that might contribute to the total inhibitory lipase activity, apparently these were less effective than phlorotannins (Table 5).

Obesity is related to adipogenesis, which is the process of pre-adipocyte differentiation into adipocytes. This process plays a central role in keeping lipid homeostasis and energy balance, by storing triglycerides (TG) and releasing free fatty acids in response to changing energy demands. Adipogenesis is regulated by multiple processes, including pre-adipocytes proliferation, differentiation, 
as well as fatty acid oxidation and synthesis, which are controlled by several factors [196,200]. Thus, the inhibitory effect of adipocyte differentiation and proliferation has been suggested to be an important strategy for preventing or treating obesity. Dieckol from E. cava [201], phloroglucinol, eckol, dieckol, dioxinodehydroeckol, and phlorofucofuroeckol A from E. stolonifera [202] and 6,6'-bieckol, 6,8'-bieckol, 8,8'-bieckol, dieckol and phlorofucofuroeckol A from E. bicyclis [203] exhibited antiobesity activity by suppressing the differentiation of 3T3-L1 pre-adipocytes cells in a dose-dependent manner. These phlorotannins were able to down-regulate the expression of the proliferator activated receptor gamma (PPAR $\gamma)$ and the CCAAT/enhancer-binding protein alpha (C/EBP $\alpha)$ [201-203]. The activation of $\mathrm{C} / \mathrm{EBP} \alpha$ promote differentiation of preadipocytes through cooperation with PPAR $\gamma$ resulting in transactivation of adipocyte-specific genes such as fatty acid binding protein (FABP) and fatty acid synthase (FAS). Sterol regulatory element-binding protein 1 (SREBP1) is the earliest transcription factor, which also appears to be involved in adipocyte differentiation, and increases the expression of several lipogenic genes, including acyl-coA carboxylase (ACC) and FAS. Therefore, over expression of these transcription factors can accelerate adipogenesis. In this sense, dieckol, moreover, down-regulated the expression of the SREBP1 and that of the FABP4 by AMPK activation [201], the latter also related to the obesity control. In addition, $6^{\prime} 6^{\prime}$-bieckol down-regulated the sterol regulatory element binding protein-1c (SREBP-1c), the FAS and the ACC [203]. Similarly, Kong et al. [204] characterized the antiadipogenic activity of triphlorethol-A, eckol and dieckol isolated from E. cava in differentiating 3T3-L1 pre-adipocytes by measuring glycerol release level and adipogenic-related gene expression. These phlorotannins increased the glycerol secretion and reduced the glucose consumption level of adipocytes. In addition, phlorotannins down-regulated the expression of PPAR $\gamma, \mathrm{C} / \mathrm{EBP} \alpha$, SREBP-1c, as well as FABP4, FAS, acyl-CoA synthetase-1 (ACS1), fatty acid transport protein-1 (FATP1) and leptin. FATP1 has been reported to take part in fatty acid utilization along with FABP4 [205]. Leptin is a hormone related to food intake and body weight reduction. Obese subjects present leptin resistance, i.e., despite this enzyme being found in high levels in these subjects, it is unable to exercise any anorexigenic effect [206]. Phlorotannins also increased mRNA expression of hormone-sensitive lipase while they suppressed perilipin and tumor necrosis factor alpha (TNF $\alpha$ ) expressions. Kim et al. [207] demonstrated that an extract containing eckol, dieckol and phlorofucofuroeckol-A from E. cava inhibited adipogenesis in 3T3-L1 adipocytes, shown by the significant reduction in glucose utilization and TG accumulation without showing cytotoxicity. This suppressive effect may be mediated by decreasing the expression levels of $\mathrm{C} / \mathrm{EBP} \alpha, \mathrm{SREBP}-1 \mathrm{c}$, adipocyte fatty acid binding protein (A-FABP), FAS and adiponectin (Table 4). Karadeniz et al. [208] also confirmed the antiadipogenic effect of triphlorethol-A, eckol and dieckol isolated from E. cava on 3T3-L1 pre-adipocytes, by reducing lipid accumulation and suppressing the expression of adipogenic differentiation markers. Considering that adipocytes and osteoblasts are derived from a common mesenchymal stem cell precursor, molecules that lead to osteoblastogenesis inhibit adipogenesis and vice versa. Thus, these authors also observed that the isolated phlorotannins successfully enhanced the osteoblast differentiation evaluated in MC3T3-E1 pre-osteoblasts, by increasing the alkaline phosphatase activity along with raising the osteoblastogenesis indicators and intracellular calcification. These results showed the potential of the selected phlorotannins for mitigating obesity and osteoporosis, which are closely related [208].

A complete study developed by Choi et al. [209] demonstrated that dieckol, a major phlorotannin in E. cava, suppressed lipid accumulation in 3T3-L1 cells, high-fat diet-fed zebrafish and mice (15 mg/kg bw/day and $60 \mathrm{mg} / \mathrm{kg}$ bw/day for 11 weeks). Furthermore, the findings suggested that dieckol was able to inhibit early adipogenic events by suppressing cell cycle progression, and played an important role in regulating AMPK $\alpha$, ERK, and Akt signaling pathways to inhibit lipid accumulation. Recently, Ko et al. [210] demonstrated that the treatment of 3T3-L1 pre-adipocytes with 5-bromo-3,4-dihydroxybenzaldehyde isolated from the red alga Polysiphonia morrowii could inhibit intracellular lipid accumulation and TG levels by downregulating protein expression of adipogenic-specific factors such as PPAR $\gamma, \mathrm{C} / \mathrm{EBP} \alpha$, SREBP-1, FABP4, FAS, leptin, and adiponectin through phosphorylation of AMPK and ACC (Table 5). 
Visceral obesity is characterized by chronic local and systemic inflammation [195]. It is well established that an increase in pro-inflammatory cytokines may be related to enlarged adipose tissue, and dysregulation of lipid metabolism, ultimately leading to insulin resistance. Thus, a phlorotannin fraction from the brown alga Fucus distichus decreased mRNA expression of acute and chronic inflammatory biomarkers via TRL attenuation in RAW 264.7 macrophages. Additionally, F. distichus fractions decreased lipid accumulation in 3T3-L1 adipocytes up to 55\% and increased free glycerol concentrations, by increasing in adiponectin and uncoupling protein 1 (UCP-1) and decreasing in leptin mRNA expression [211]. Compared with lean adipocytes, hypertrophic adipocytes had higher expression of inflammatory cytokines (e.g., TNF $\alpha$, interleukin (IL)-1 $\beta$ ) and of receptors for advanced glycation end-products (RAGEs) and RAGE ligands (e.g., AGE, HMGB1, S100b, free fatty acids (FFAs)) [212]. Choi et al. [213] demonstrated the antiobesity effect of pyrogallol-phloroglucinol-6,6-bieckol (PPB) contained in E. cava by reducing the expression of RAGE and the secretion of ligands in a mouse model of diet-induced obesity that consumed PPB $(2.5 \mathrm{mg} / \mathrm{kg} \mathrm{bw} /$ day) for 4 weeks. In addition, this phlorotannin reduced the number of activated macrophages and inflammatory cytokine levels (TNF $\alpha$ and IL-1 $\beta$ ).

The regulatory effect of marine phenolics on lipid metabolism has also been evaluated. Typically, dyslipidemia of obesity consists of increased fasting plasma TG and FFAs, decreased HDL-cholesterol (HDL-C) and normal or slightly increased LDL-cholesterol (LDL-C). Yeo et al. [214] demonstrated that oral administration of polyphenol extracts of the marine brown algae E. cava and dieckol effectively suppressed body weight gain and reduced total cholesterol (TC), TG and LDL-C levels in high-fat diet-induced obese mice treated with 1.25, 2.5 and $5.0 \mathrm{mg}$ extract/mouse or $0.5,1.0$ and $2.0 \mathrm{mg} \mathrm{dieckol} / \mathrm{mouse}$ for 4 weeks. The antihyperlipidemic effect was related to the inhibition of 3-hydroxyl-methyl glutaryl coenzyme A (HMGCoA) reductase activity, which is involved in the metabolic pathway that produces cholesterol and other isoprenoids. Likewise, Park et al. [215] confirmed the antiobesity activity of a polyphenol-rich fraction of the brown alga E. cava in high fat diet-induced obese mice. Oral administration of a polyphenol extract $(200 \mathrm{mg} / \mathrm{kg} \mathrm{bw} /$ day $)$ for 8 weeks was effective in reducing body weight gain, body fat, and hyperglycemia, as well as in improving glucose tolerance. The mRNA expression of inflammatory cytokines (TNF- $\alpha$ and IL-1 $\beta)$ and macrophage marker gene (F4/80) was decreased in treated obese mice. These authors compared the efficacy of E. cava from different areas in Korea: that from Gijang was consistently more effective than that from Jeju due to its higher amounts of polyphenols and richness in 8,8'-bieckol, the major component in Gijang extract. In agreement with Park et al. [215], a later study developed by Eo et al. [216] reported that the treatment with a polyphenol-rich extract of $E$. cava containing dieckol, 2,7'-phloroglucino-6,6'-bieckol, pyrogallo-phloroglucinol-6,6'-bieckol and phlorofucofuro-eckol A $(100 \mathrm{mg} / \mathrm{kg} \mathrm{bw} /$ day or $500 \mathrm{mg} / \mathrm{kg}$ bw/day, 5 times a week for 12 weeks) was able to reduce body weight gain, adipose tissue mass, plasma lipid levels (TC and TG), hepatic fat depositions, insulin resistance and plasma leptin/adiponectin ratio of diet-induced obese mice. Moreover, polyphenol supplementation selectively ameliorated hepatic protein levels associated with hepatic lipogenesis (SREBP-1c, PPAR $\alpha$, FAS, and LPL), fatty acid $\beta$-oxidation (p-ACC and CPT1A), inflammation (TNF- $\alpha$, IL- $1 \beta$ and NFkB) as well as enhancing the antioxidant defense system by activating the AMPK and SIRT1 signaling pathway (Table 4). Ding et al. [217] demonstrated the strong effect of diphlorethohydroxycarmalol, the most abundant bioactive compound in Ishige okamurae, against high-fat levels in diet-induced obese mice through in vivo regulation of multiple pathways. Oral administration of this polyphenol ( 25 and $50 \mathrm{mg} / \mathrm{kg}$ bw/day for six weeks) significantly reduced adiposity and body weight gain and improved lipid profile (lowered TG and LDL-C and increased HDL-C levels). This compound reduced hepatic lipid accumulation, by the reduction in expression levels of the critical enzymes for lipogenesis (SREBP-1c, FABP4, and FAS). In addition, diphlorethohydroxycarmalol reduced the adipocyte size and the expression levels of key adipogenic-specific proteins and lipogenic enzymes such as PPAR $\gamma$, $\mathrm{C} / \mathrm{EBP} \alpha$, SREBP-1c, FABP4, and FAS, which regulate the lipid metabolism in the epididymal adipose 
tissue. Finally, diphlorethohydroxycarmalol stimulated the phosphorylation of AMPK and ACC in both liver and epididymal adipose tissue.

Clinical trials also have demonstrated the potential of marine phenolics to prevent obesity. The efficacy of a polyphenol-rich extract from E. cava (low dose-72 mg/day or high dose-144 mg/day) was tested in 97 overweight adults enrolled in a randomized, double-blind, placebo-controlled clinical trial with parallel-group design. Results demonstrated that the polyphenol-rich extract consumed for 12 weeks lowered body fat and serum lipid levels (TC and LDL-C) [218].

All these data together highlight the potential of marine phenols in the prevention and treatment of obesity (Table 5, Figure 2), although more studies, especially clinical trials, would reinforce their use in the management of obesity. 
Table 5. Effect of marine phenolics in the prevention of obesity.

\begin{tabular}{|c|c|c|c|}
\hline Compounds/Marine Source & Test Model & Outcome & Ref. \\
\hline $\begin{array}{c}\text { Methanolic extract of E. bicyclis (eckol, fucofuroeckol A, } \\
\text { 7-phloroeckol, dioxindehydroeckol, phlorofucofuroeckol A, } \\
\text { and dieckol) }\end{array}$ & In vitro: assay of pancreatic lipase activity & $\begin{array}{l}\text { Inhibition of pancreatic lipase activity; fucofuroeckol } \mathrm{A} \text { and } \\
\text { 7-phloroeckol were the most potent (IC } 5_{50} \text { values of } 37.2 \text { and } \\
12.7 \mu \mathrm{M} \text {, respectively) }\end{array}$ & {$[198$} \\
\hline $\begin{array}{l}\text { Polyphenol-rich extract (crude) from the edible seaweed A. nodosum } \\
\text { and phlorotannin-enriched fraction from crude extract }\end{array}$ & In vitro: assay of pancreatic lipase activity & $\begin{array}{c}\text { Inhibition of pancreatic lipase activity } \\
\text { Evaluated the interaction between phlorotannins and } \\
\text { polysaccharides on inhibitory lipase activity and phlorotannins were } \\
\text { more effective }\end{array}$ & {$[199$} \\
\hline Dieckol isolated from E. cava & In vitro: 3T3-L1 pre-adipocytes cells (25-100 $\mu \mathrm{M}$ of phenol) & $\begin{array}{c}\text { Suppression of pre-adipocytes differentiation } \\
\text { Down-regulated the expression of PPAR } \gamma, \text { C/EBP } \alpha, \text { SREBP1 and } \\
\text { FABP4 by AMPK activation }\end{array}$ & {$[201]$} \\
\hline $\begin{array}{l}\text { Phloroglucinol, eckol, dieckol, dioxinodehydroeckol, } \\
\text { and phlorofucofuroeckol A isolated from E. stolonifera }\end{array}$ & In vitro: 3T3-L1 pre-adipocytes cells (12.5-100 $\mu \mathrm{M}$ of phenol) & $\begin{array}{l}\text { Suppression of pre-adipocytes differentiation } \\
\text { Down-regulated the expression of PPAR } \gamma \text { and } C / E B P \alpha\end{array}$ & {$[202$} \\
\hline $\begin{array}{l}\text { 6, } 6^{\prime} \text {-Bieckol, } 6,8^{\prime} \text {-bieckol, } 8,8^{\prime} \text {-bieckol, dieckol and } \\
\text { phlorofucofuroeckol A isolated from E. bicyclis }\end{array}$ & In vitro: 3T3-L1 pre-adipocytes cells $(10-50 \mu \mathrm{g} / \mathrm{mL}$ of phenol) & $\begin{array}{c}\text { Suppression of pre-adipocytes differentiation } \\
\begin{array}{c}\text { Down-regulated the expression of PPAR } \gamma, \mathrm{C} / \mathrm{EBP} \alpha, \text { SREBP-1c, FAS } \\
\text { and ACC }\end{array}\end{array}$ & {$[195]$} \\
\hline Triphlorethol-A, eckol and dieckol from E. cava & In vitro: 3T3-L1 pre-adipocytes cells ( $5 \mu \mathrm{M}$ of phenol) & $\begin{array}{l}\text { Increased the glycerol secretion and reduced glucose } \\
\text { consumption level } \\
\text { Down-regulated the expression of PPAR } \gamma, \text { C/EBP } \alpha \text {, SREBP-1c as well } \\
\text { as FABP4, FATP1, FAS, leptin and ACSL1 }\end{array}$ & {$[204]$} \\
\hline $\begin{array}{l}\text { Extract from E. cava containing eckol, dieckol and } \\
\text { phlorofucofuroeckol-A }\end{array}$ & $\begin{array}{l}\text { In vitro: } 3 \mathrm{~T} 3 \text { - } \mathrm{L} 1 \text { adipocytes cells } \\
\quad(50 \mu \mathrm{g} / \mathrm{mL} \text { of extract })\end{array}$ & $\begin{array}{l}\text { Inhibited the glucose utilization and TG accumulation } \\
\text { Down-regulated the expression of C/EBP } \alpha \text {, SREBP-1c, A-FABP, FAS } \\
\text { and adiponectin }\end{array}$ & {$[207]$} \\
\hline Triphlorethol-A, eckol and dieckol isolated from E. cava & $\begin{array}{l}\text { In vitro: 3T3-L1 pre-adipocytes cells (1-20 } \mu \mathrm{M} \text { of phenol) } \\
\text { In vitro: MC3T3-E1 cells (1-20 } \mu \mathrm{M} \text { of phenol) }\end{array}$ & $\begin{array}{l}\text { Suppressed the lipid accumulation and expression of adipogenic } \\
\text { differentiation markers } \\
\text { Enhanced the osteoblast differentiation by increasing alkaline } \\
\text { phosphatase activity and raising intracellular calcification }\end{array}$ & {$[208$} \\
\hline Dieckol from E. cava & $\begin{array}{l}\text { In vitro: 3T3-L1 pre-adipocytes cells ( } 25-100 \mu \mathrm{M} \text { of phenol) } \\
- \\
\text { In vivo: high-fat diet-fed zebrafish (1-4 } \mu \mathrm{M} \text { of phenol) } \\
\text { In vivo: high-fat diet-fed mice }(15 \mathrm{mg} / \mathrm{kg} \text { bw/day or } \\
60 \mathrm{mg} / \mathrm{kg} \text { bw/day, } 11 \text { weeks administered orally })\end{array}$ & $\begin{array}{c}\text { Suppressed the lipid accumulation in the three models } \\
\text { Inhibited the early adipogenic events by suppressing cell } \\
\text { cycle progression } \\
\text { Regulated the AMPK } \alpha, \text { ERK, and Akt signaling to inhibit } \\
\text { lipid accumulation }\end{array}$ & {$[209$} \\
\hline $\begin{array}{l}\text { 5-Bromo-3,4-dihydroxybenzaldehyde isolated from } \\
\text { Polysiphonia morrow }\end{array}$ & In vitro: 3 T3-L1 pre-adipocytes cells $(25-100 \mu \mathrm{M})$ & $\begin{array}{l}\text { Inhibited the intracellular lipid accumulation and triglyceride levels } \\
\text { Down-regulated the expression of PPAR } \gamma, \text { C/EBP } \alpha \text {, SREBP-1, FABP4, } \\
\text { FAS, leptin, and adiponectin by AMPK and ACC activation. }\end{array}$ & {$[210]$} \\
\hline Phlorotannin fraction from Fucus distichus & $\begin{array}{c}\text { In vitro: murine macrophage RAW } 264.7 \text { cells }(12.5-50 \mu \mathrm{g} / \mathrm{mL} \\
\text { of extract) } \\
-\begin{array}{c}- \\
\text { In vitro: 3T3-L1 adipocytes cells }(12.5-50 \mu \mathrm{g} / \mathrm{mL} \text { of extract) }\end{array}\end{array}$ & $\begin{array}{c}\text { Anti-inflammatory activity via TLR attenuation in macrophages } \\
- \\
\text { Decreased the lipid accumulation in 3T3-L1 adipocytes cells }\end{array}$ & {$[211]$} \\
\hline Pyrogallol-phloroglucinol-6,6-bieckol from E. cava & $\begin{array}{l}\text { In vivo: mouse model of diet-induced obesity }(2.5 \mathrm{mg} / \mathrm{kg} \text { bw/day for } \\
4 \text { weeks administered orally) }\end{array}$ & $\begin{array}{l}\text { Reduced the expression of RAGE and the secretion of ligands } \\
\text { Reduced the inflammatory cytokine level (TNF } \alpha \text { and IL-1 } 1 \beta \text { ) }\end{array}$ & {$[213]$} \\
\hline
\end{tabular}


Table 5. Cont.

\begin{tabular}{|c|c|c|c|}
\hline Compounds/Marine Source & Test Model & Outcome & Ref. \\
\hline Polyphenol extracts from E. cava and dieckol & $\begin{array}{c}\text { In vivo: high-fat diet-induced obese mice }(5.0 \mathrm{mg}, 2.5 \mathrm{mg} \text { and } \\
1.25 \mathrm{mg} \text { extract/mouse; } 2.0 \mathrm{mg}, 1.0 \mathrm{mg} \text { and } 0.5 \mathrm{mg} \text { dieckol/mouse for } \\
4 \text { weeks administered orally) } \\
\text { In vitro: } 3 \text { T3-L1 pre-adipocytes cells }\end{array}$ & $\begin{array}{l}\text { Suppressed the body weight gain } \\
\text { Reduced the TC, TG and LDL-C levels } \\
\text { Inhibited the lipid accumulation } \\
\text { Inhibition of HMGCoA reductase activity }\end{array}$ & [214] \\
\hline Polyphenol-rich fraction of E. cava from Gijang (Korea) & $\begin{array}{l}\text { In vivo: high-fat diet-induced obese mice ( } 200 \mathrm{mg} / \mathrm{kg} \text { bw for } 8 \text { weeks } \\
\text { by oral intubation) }\end{array}$ & $\begin{array}{l}\text { Reduced the body weight gain, body fat and hyperglycemia } \\
\text { Reduced the mRNA expression of inflammatory cytokines (TNF- } \alpha \\
\text { and IL-1 } \beta \text { ) and macrophage marker gene (F4/80) }\end{array}$ & [215] \\
\hline $\begin{array}{l}\text { Polyphenol-rich fraction of E. cava containing dieckol, } \\
2,77^{\prime \prime} \text {-phloroglucino-6,6'-bieckol, } \\
\text { pyrogallo-phloroglucinol-6,6'-bieckol and phlorofucofuro-eckol A }\end{array}$ & $\begin{array}{l}\text { In vivo: high-fat diet-induced obese mice }(100 \mathrm{mg} / \mathrm{kg} \text { bw/day or } \\
500 \mathrm{mg} / \mathrm{kg} \text { bw/day, } 5 \text { times a week for } 12 \text { weeks by gavage) }\end{array}$ & $\begin{array}{c}\text { Reduced the body weight gain, body fat, plasma lipid levels (TC and } \\
\text { TG), insulin resistance and plasma leptin/adiponectin ratio } \\
\text { Ameliorated the hepatic protein levels: hepatic lipogenesis (PPAR } \gamma \text {, } \\
\text { SREBP-1c, FAS and LPL), fatty acid } \beta \text {-oxidation (p-ACC and CPT1A), } \\
\text { inflammation (TNF- } \alpha \text {, NFkB and IL-1 } \beta \text { ) and antioxidant } \\
\text { defense system }\end{array}$ & [216] \\
\hline Diphlorethohydroxycarmalol isolated from Ishige okamurae & $\begin{array}{l}\text { In vivo: high-fat diet-induced obese mice }(25 \mathrm{mg} / \mathrm{kg} \text { bw/day or } \\
50 \mathrm{mg} / \mathrm{kg} \text { bw/day for } 6 \text { weeks administered orally })\end{array}$ & $\begin{array}{c}\text { Reduced the body weight gain, body fat and hepatic lipid } \\
\text { accumulation, and improved lipid profile } \\
\text { Reduced the hepatic lipid accumulation by reduction in expression } \\
\text { level of SREBP-1c, FABP4, and FAS } \\
\text { Reduced the adipocyte size by down-regulation of enzyme } \\
\text { expression (PPAR } \gamma, \text { C } / E B P \alpha, \text { SREBP-1c, FABP4, and FAS) }\end{array}$ & [217] \\
\hline Polyphenol-rich extract from E. cava & $\begin{array}{c}\text { In vivo: } 97 \text { overweight adults (low dose-72 mg/day or high } \\
\text { dose-144 mg/day for } 12 \text { weeks) }\end{array}$ & Decreased the body fat and serum lipoid levels (TC and LDL-C) & [218] \\
\hline
\end{tabular}

PPAR $\gamma$ : proliferator activated receptor gamma; C/EBP $\alpha$ : CCAAT/enhancer-binding protein alpha; SREBP1: sterol regulatory element binding protein 1; FABP4: fatty acid binding protein 4;

AMPK: AMP-activated protein kinase; SREBP-1c: sterol regulatory element binding protein-1c; FAS: fatty acid synthase; ACC: acyl-CoA carboxylase; FATP1: fatty acid transport protein-1;

ACSL1: adipose acyl-CoA synthetase 1; ERK: extracellular signal-regulated kinase; Akt: protein kinase B; TLR: toll-like receptor; RAGE: receptor for advanced glycation end-products;

$\mathrm{TNF} \alpha$ : tumor necrosis factor alpha; IL-1 $\beta$ : interleukin 1b; TC: total cholesterol; TG: triglycerides; LDL-C: LDL-cholesterol; HMGCoA: 3-hydroxyl-methyl glutaryl coenzyme A; ACC:

acetyl-CoA carboxylase; CPT1A: carnitine palmitoyltransferase I; NFkB: nuclear factor kappa B. 


\subsection{Metabolic Syndrome.}

Metabolic syndrome (MetS) is not a disease but a metabolic disorder that includes hypertension, obesity, glucose dysregulation and dyslipidemia [219]. A person has MetS when three or more of the following five cardiovascular risk factors have been diagnosed: (i) central obesity (waist circumference: men $\geq 102 \mathrm{~cm}$; women $\geq 88 \mathrm{~cm}$ ); (ii) elevated TG ( $\geq 150 \mathrm{mg} / \mathrm{dL})$; (iii) diminished HDL-C (men $<40 \mathrm{mg} / \mathrm{dL}$; women $<50 \mathrm{mg} / \mathrm{dL}$ ) (or treated for dyslipidemia); (iv) systemic hypertension ( $\geq 130 / \geq 85 \mathrm{~mm} \mathrm{Hg}$ ) (or treated for hypertension); (v) elevated fasting glucose ( $\geq 100 \mathrm{mg} / \mathrm{dL}$ ) (or treated for hyperglycemia) [220]. MetS appears to be two times more frequent in women than in men, and menopause contributes to its rapid acceleration [221]. A recent study examined prospectively the association between habitual dietary iodine and seaweed consumption and the incidence of MetS among 2588 postmenopausal women 40 years or older in the Korean Multi-Rural Communities Cohort (MRCohort) [222] for an average time of 2.85 years (between 2 and 4 years). Results showed an inverse association between seaweed consumption with MetS incidence. The unmeasured bioactives of seaweed, such as polysaccharides, peptides, carotenoids and polyphenols, make it difficult to understand the real involvement of marine phenolics in the observed effects (Table 6). 
Table 6. Effect of marine phenolics in the prevention of metabolic syndrome (MetS).

\begin{tabular}{|c|c|c|c|}
\hline Compounds/Marine Source & Test Model & Outcome & Ref. \\
\hline Dietary iodine and seaweed consumption & $\begin{array}{l}\text { In vivo: } 2588 \text { postmenopausal women for } 2.85 \text { years } \\
\text { (between } 2 \text { and } 4 \text { years) }\end{array}$ & $\begin{array}{l}\text { Inverse association between seaweed consumption with } \\
\text { MetS incidence }\end{array}$ & {$[222$} \\
\hline Bioactive fraction of Sargassum wightii & $\begin{array}{l}\text { In vitro: assays of ACE enzyme activity and antioxidant activity } \\
\text { (DPPH, ABTS and FRAP) }\end{array}$ & $\begin{array}{l}\text { Inhibition of ACE activity }\left(\mathrm{IC}_{50} 56.96 \mu \mathrm{g} / \mathrm{mL}\right) \text { and improved the } \\
\text { antioxidant potency determined }\end{array}$ & {$[223$} \\
\hline $\begin{array}{l}\text { An extract l from E. cava and } \\
\text { pyrogallol-phloroglucinol-6,6-bieckol }\end{array}$ & $\begin{array}{l}\text { In vivo: two mice models, high-fat diet-induced obese mice and } \\
\text { high-cholesterol and saline diet-induced hypertension mice } \\
\text { (70 mg extract or } 500 \mathrm{mg} \text { extract or } 2.5 \mathrm{mg} \text { pure phenol/kg bw/day } \\
\text { for } 4 \text { weeks administered orally) } \\
\text { In vitro: VSMC cells, an endothelial cell line }\end{array}$ & $\begin{array}{l}\text { Reduced the blood pressure and serum lipoprotein levels in vivo } \\
\text { Reduced the adhesion molecule expression, endothelial cell death } \\
\text { and excessive migration and proliferation of VSMCs in vitro, as well } \\
\text { as in the obese and hypertension mouse models }\end{array}$ & {$[224]$} \\
\hline $\begin{array}{l}\text { Ethanolic extract from Ulva lactuca enriched } \\
\text { in phlorotannins }\end{array}$ & $\begin{array}{l}\text { In vivo: hypercholesterolemic mice }(250 \mathrm{mg} / \mathrm{kg} \text { body weight for } \\
4 \text { weeks by gavage) }\end{array}$ & $\begin{array}{l}\text { Improved the heart oxidative stress, plasma biochemical parameters } \\
\text { and index of atherogenesis } \\
\text { Down-regulated the expression of pro-inflammatory cytokines } \\
\text { (TNF } \alpha \text {, IL- } 1 \beta \text { and IL-6) in the heart }\end{array}$ & {$[225$} \\
\hline Food supplement from K. alvarezii & $\begin{array}{l}\text { In vivo: rats fed for } 8 \text { weeks on high-carbohydrate, high-fat diet, } \\
\text { alone or supplemented with } 5 \%(w / w) \text { algae }\end{array}$ & $\begin{array}{c}\text { Reduced the body weight, adiposity, systolic blood pressure and } \\
\text { plasma lipid levels } \\
\text { Improved the heart and liver structure }\end{array}$ & {$[226$} \\
\hline
\end{tabular}

VSMC: human vascular smooth muscle cell line; TNF $\alpha$ : tumor necrosis factor alpha; IL-1 $\beta$; interleukin 1 $1 \beta$; IL-6: interleukin 6 - 
The aforementioned in vitro and in vivo studies have evidenced the involvement of marine phenolics in regulating lipid metabolism, hyperglycemia and obesity; these studies were reviewed by Gomez-Guzman et al. [227]. Additionally, hypertension, which is a strong independent risk factor for stroke and coronary heart disease, is also a cardiovascular risk factor in patients with MetS [228]. Angiotensin-I converting enzyme (ACE) is a zinc-containing metalloproteinase that catalyzes the conversion of angiotensin I to angiotensin II, a potent vasoconstrictor involved in the pathogenesis of hypertension. ACE also facilitates the degradation of the vasodilator bradykinin. This enzyme has a crucial role in the control of blood pressure and its inhibition has become a major target for hypertension control. Seca et al. [229] recently reviewed several marine polyphenols that have been reported to inhibit ACE activity. A bioactive fraction of the brown algae Sargassum wightii with optimal antioxidant and ACE inhibition activities $\left(\mathrm{IC}_{50} 56.96 \mu \mathrm{g} / \mathrm{mL}\right.$ ) was characterized by Vijayan et al. [223]. An in vivo study evaluated the efficacy of a polyphenol-rich extract from E. cava as well as its major component (pyrogallol-phloroglucinol-6,6-bieckol) for improving blood circulation in diet-induced obese and diet-induced hypertension mouse models [224]. After four weeks of administering $70 \mathrm{mg}$ and $500 \mathrm{mg}$ of extract $/ \mathrm{kg} \mathrm{bw}$ or $2.5 \mathrm{mg}$ of phenol $/ \mathrm{kg} \mathrm{bw}$, the study found a reduction in blood pressure and in serum lipoprotein levels in the obese and hypertension mouse models. A reduced expression of adhesion molecules and endothelial cell death as well as a reduction in excessive migration and proliferation of vascular smooth cells was also observed (Table 6).

In vivo studies with animals supplemented with diet-induced MetS have also evidenced the potential of seaweed polyphenols to prevent metabolic disorders. An ethanolic extract from $U$. lactuca enriched in phlorotannins was tested against hypercholesterolemia and other risk factors involved in CVD. Treatment of hypercholesterolemic mice with $U$. lactuca extract $(250 \mathrm{mg} / \mathrm{kg}$ body weight) for 4 weeks revealed a cardioprotective effect by improving heart oxidative stress, plasma biochemical parameters, and index of atherogenesis. Additionally, a reduction in gene expression of proinflammatory cytokines (TNF $\alpha, \mathrm{IL}-1 \beta$ and IL-6) in the heart of $U$. lactuca-supplemented animals was also observed [225]. Kappaphycus alvarezii, a red seaweed, was tested as a food supplement to prevent diet-induced MetS in rats. Rats were randomly divided and fed for 8 weeks with control diet or high-fat/high-carbohydrate diet supplemented with 5\% (w/w) algae. Kappaphycus-treated rats showed normalized body weight and adiposity, lower systolic blood pressure, improved heart and liver structure, and lower plasma lipids [226]. The hypotensive activity of marine polyphenols, in addition to their antidiabetic, antilipidemic and antiobesity activities, turns this group of compounds into allies to combat MetS and related cardiovascular complications (Table 6 and Figure 2).

\subsection{Neurodegenerative Diseases}

Seaweed-derived phenols have been described to possess neuroprotective properties [230]. Although this pathology has been less explored than those described above, knowing the role of phenolic constituents of seaweed as neuro-active compounds has gained tremendous interest in the last decade. Alzheimer's disease (AD) is the most common form of irreversible dementia, and its neuropathological hallmarks are characterized by amyloid plaques and neurofibrillary tangles composed of aggregated amyloid- $\beta$ peptides $(\mathrm{A} \beta)$ and microtubule-associated protein tau, respectively [231]. Although the exact mechanisms of $A \beta$-induced neurotoxicity are still unclear, it has been reported that pathological deposition of $A \beta$ leads to cholinergic dysfunction, glutamate excitotoxicity, beta-amyloid aggregation, oxidative stress, apoptosis and neuro-inflammation, inducing the progressive degeneration of cognitive functions in AD patients (Figure 2).

$\mathrm{AD}$ development has been linked with an impaired cholinergic pathway which is caused by upregulation of acetylcholinesterase (AChE) and butyrylcholinesterases (BChE) as well as rapid depletion of acetylcholine (AChE) [232]. In addition, BACE-1 ( $\beta$-site amyloid precursor protein cleaving enzyme 1 ) is the major $\beta$-secretase for generation of $A \beta$ by neurons [233] and its inhibition could block one of the earliest pathologic events in AD. The activity of some phlorotannins, in particular eckols from E. cava [234] and E. bicyclis [235], showed an inhibitory effect against AChE and BChE 
activities, higher than the currently used anti-AD drugs. Recently, aqueous extracts of some seaweeds (G. beckeri, G. pristoides, Ulva rigida and Ecklonia maxima), composed mainly by phloroglucinol, catechin and epicatechin 3-glucoside, showed high antioxidant potency, inhibitory activity of AChE and BChE enzymes and $A \beta$ aggregation [236] (Table 7). The study by Olasehinde et al. [237] revealed that aqueous-ethanolic extracts of G. pristoides, E. maxima, U. lactuca and G. gracilis containing phlorotannins, flavonoids and phenolic acids exhibited a strong inhibitory activity of BACE-1, AChE and BChE enzymes, as well as hampered $A \beta$ aggregation. Choi et al. [234] showed that phlorofucofuroeckol isolated from E. cava also reduced BACE-1 activity ( $\mathrm{IC}_{50}$ values in Table 7).

Table 7. Effect of marine phenolics in the prevention of Alzheimer's disease (AD).

\begin{tabular}{|c|c|c|c|}
\hline Compounds/Marine Source & Test Model & Outcome & Ref. \\
\hline $\begin{array}{l}\text { Phlorotannin-rich extract from E. cava } \\
\text { (dieckol, 6,6'-bieckol, 8,8'-bieckol, eckol } \\
\text { and phlorofucofuroeckol-A) }\end{array}$ & $\begin{array}{c}\text { In vitro: assays of } \mathrm{AChE}, \mathrm{BChE} \text { and } \\
\text { BACE-1 activities } \\
- \\
\text { In vitro: Jurkat clone } \mathrm{E} 1-6 \text { cells }(\mathrm{GSK} 3 \beta \\
\text { activity at } 50 \mu \mathrm{M})\end{array}$ & $\begin{array}{c}\text { Inhibition of } A C h E \text { and } B C h E \text { activities } \\
\text { (IC } 5016.0-96.3 \mu \mathrm{M} \text { and } \\
0.9-29.0 \mu \mathrm{M} \text {, respectively) } \\
\text { Inhibition of BACE- } 1 \text { activity } \\
(18.6-58.3 \% \text { at } 1 \mu \mathrm{M}) \\
\text { Inhibition of GSK3 } \beta \text { activity } \\
(14.4-39.7 \% \text { at } 50 \mu \mathrm{M})\end{array}$ & [234] \\
\hline $\begin{array}{l}\text { Phlorotannin-rich extract } \\
\text { from E. bicyclis (eckols) }\end{array}$ & $\begin{array}{l}\text { In vitro: assays of } \mathrm{AChE} \text { and } \\
\text { BChE activities }\end{array}$ & $\begin{array}{l}\text { Inhibition of } \mathrm{AChE} \text { and } \mathrm{BChE} \text { activities } \\
\text { (IC } 502.78 \text { and } 3.48 \mu \mathrm{g} / \mathrm{mL} \text {, respectively) }\end{array}$ & [235] \\
\hline $\begin{array}{l}\text { Aqueous extracts of Gracilaria beckeri, } \\
\text { Gelidium pristoides, } U \text {. rigida and E. maxima } \\
\text { composed by phloroglucinol, catechin and } \\
\text { epicatechin 3-glucoside }\end{array}$ & $\begin{array}{l}\text { In vitro: assays of } \mathrm{AChE} \text { and } \\
\text { BChE activities }\end{array}$ & $\begin{array}{c}\text { High antioxidant potency } \\
\text { Inhibition of } \mathrm{AChE} \text { and } \mathrm{BChE} \text { activities } \\
\left(\mathrm{IC}_{50} 49.41 \text { and } 52.11 \mu \mathrm{g} / \mathrm{mL} \text {, respectively, }\right. \\
\text { for } E \text {. maxima }) \\
\text { Inhibition of } \mathrm{A} \beta \text { aggregation }\end{array}$ & [236] \\
\hline $\begin{array}{l}\text { Aqueous-ethanolic extracts from E. maxima, } \\
\text { G. pristoides, Gracilaria gracilis, } \\
\text { and Ulva lactuca containing phlorotannins, } \\
\text { flavonoids and phenolic acids }\end{array}$ & $\begin{array}{l}\text { In vitro: assays of } \mathrm{AChE}, \mathrm{BChE} \text { and } \\
\text { BACE-1 activities }\end{array}$ & $\begin{array}{c}\text { Inhibition of } \mathrm{AChE} \text { and } \mathrm{BChE} \text { activities } \\
\left(\mathrm{IC}_{50} 1.74-2.42 \text { and }\right. \\
1.55-2.04 \mathrm{mg} / \mathrm{mL} \text {, respectively) } \\
\text { Inhibition of } \mathrm{BACE}-1 \text { activity } \\
\left(\mathrm{IC} \mathrm{C}_{50} 0.052-0.062 \mathrm{mg} / \mathrm{mL}\right) \\
\text { Inhibition of } \mathrm{A} \beta \text { aggregation }\end{array}$ & [237] \\
\hline Phlorofucofuroeckol isolated from E. cava & $\begin{array}{l}\text { In vitro: Glutamate-stimulated PC12 cells } \\
\qquad(10 \mu \mathrm{M} \text { of phenol })\end{array}$ & $\begin{array}{l}\text { Increased the cell viability and attenuated } \\
\text { glutamate excitotoxicity } \\
\text { Inhibited the apoptosis in a } \\
\text { caspase-dependent manner } \\
\text { Regulated the production of ROS and } \\
\text { attenuated mitochondrial dysfunction }\end{array}$ & [238] \\
\hline Phloroglucinol isolated from E. cava & $\begin{array}{l}\text { In vitro: } \mathrm{A} \beta \text {-induced neurotoxicity in } \\
\mathrm{HT}-22 \text { cells }(10 \mu \mathrm{g} / \mathrm{mL}) \\
- \\
\text { In vivo: } 5 \text { XFAD mice, model of AD (acute, } \\
1.2 \mu \mathrm{mol} \text { of phenol bilaterally delivery) }\end{array}$ & $\begin{array}{l}\text { Reduced the } \mathrm{A} \beta \text {-induced ROS } \\
\text { accumulation in HT- } 22 \text { cells } \\
\text { Ameliorated the reduction in dendritic } \\
\text { spine density } \\
\text { - } \\
\text { Attenuated the impairments in } \\
\text { cognitive dysfunction }\end{array}$ & [239] \\
\hline Eckmaxol from E. maxima & $\begin{array}{l}\text { In vitro: } A \beta \text { oligomer-induced } \\
\text { neurotoxicity in SH-SY5Y cells } \\
\quad(5-20 \mu \mathrm{M} \text { of phenol })\end{array}$ & $\begin{array}{l}\text { Prevented the A } \beta \\
\text { oligomer-induced neurotoxicity } \\
\text { Inhibition of GSK } 3 \beta \text { and ERK } \\
\text { signaling pathway }\end{array}$ & [240] \\
\hline $\begin{array}{l}\text { E. cava rich in phlorotannins (eckol, } \\
\text { 8,80-bieckol and dieckol) }\end{array}$ & $\begin{array}{l}\text { In vitro: } A \beta 25-35 \text {-induced damage in } \\
\text { PC12 Cells (1-50 } \mu \mathrm{M} \text { of phenol) }\end{array}$ & $\begin{array}{c}\text { Inhibition of pro-inflammatory enzymes } \\
\text { preventing } A \beta \text { production and } \\
\text { neurotoxicity on the brain }\end{array}$ & [241] \\
\hline $\begin{array}{l}\text { Phlorotannin-rich fraction } \\
\text { from Ishige foliacea }\end{array}$ & $\begin{array}{l}\text { In vivo: scopolamine-induced amnesic } \\
\text { mice ( } 50 \text { and } 100 \mathrm{mg} / \mathrm{kg} \text { bw/day of extract } \\
\text { orally administered for } 6 \text { weeks) }\end{array}$ & $\begin{array}{l}\text { Inhibition of AChE activity in the brain } \\
\text { Improved the status antioxidant } \\
\text { Prevented the memory impairment via } \\
\text { regulation of ERK-CREB-BDNF pathway }\end{array}$ & [242] \\
\hline
\end{tabular}

AD: alzheimer's disease; AChE: acetylcholinesterase; BChE: butyrylcholinesterase; BACE-1: beta-site amyloid precursor protein cleaving enzyme 1 ; $A \beta$ : amyloid- $\beta$ peptides; GSK3 $\beta$ : glycogen synthase kinase $3 \beta$; ROS: reactive oxygen species; ERK: extracellular signal-regulated kinase; BDNF: brain-derived neurotrophic factor.

Glutamate is an important neurotransmitter responsible for memory, learning and cognitive function. However, excessive glutamate release from the presynaptic terminals has also been suggested as a mechanism for increased $\mathrm{A} \beta$ production via NMDA receptor-mediated $\mathrm{Ca}^{2+}$ influx [243]. Hence, administering biological active compounds capable of protecting the brain cells against glutamate excitotoxicity may be an appealing therapeutic intervention. Phlorofucofuroeckol isolated from E. cava increased cell viability in glutamate-stimulated PC12 cells, attenuating glutamate excitotoxicity. Kim et al. [238] showed that phlorofucofuroeckol inhibits glutamate-induced 
apoptotic cell death in a caspase-dependent manner, regulates the production of ROS and attenuates mitochondrial dysfunction.

No drug has been developed yet to combat $A \beta$ aggregation, although some marine phenolics have shown the ability to attenuate $A \beta$-induced neurotoxicity in AD models. Phloroglucinol isolated from E. cava reduced ROS generation caused by A $\beta$-induced neurotoxicity in HT-22 cells. Yang et al. [239] have shown that phloroglucinol ameliorated the reduction in dendritic spine density induced by $\mathrm{A} \beta$ treatment in rat primary hippocampal neuron cultures. Administration of phloroglucinol to the hippocampal region attenuated the impairments in cognitive dysfunction 5XFAD mice, an animal model of AD [239]. Eckols from E. cava demonstrated it is able to inhibit glycogen synthase kinase $3 \beta$ (GSK3 $\beta$ ), which inhibits the biosynthesis of amyloid precursor proteins and is related to the formation of hyperphosphorylated tau and the generation of $A \beta$ [234]. Likewise, eckmaxol isolated from Ecklonia maxima also prevented A $\beta$ oligomer induced neurotoxicity in SH-SY5Y cells, via the inhibition of glycogen synthase kinase $3 \beta$ (GSK3 $\beta$ ) and the ERK signaling pathway [240]. Neurodegenerative disorders are often characterized by a wide range of diverse and intertwined neuro-inflammatory processes, leading to primary or secondary central nervous system damage. A recent study showed that eckols, 8,8'-bieckol and dieckol, were able to inhibit TNF $\alpha$, IL-1 $\beta$ and prostaglandin E2 (PGE2) production at protein level, related to the down-regulation of proinflammatory enzymes, iNOS and COX-2, through the negative regulation of the NF-kB pathway in $\mathrm{A} \beta_{25-35}$-stimulated PC12 cells, preventing the neurotoxicity on the brain. Especially, dieckol showed strongest anti-inflammatory effects via suppression of p38, ERK and JNK [241]. Um et al. [242] assessed the neuroprotective activity of a phlorotannin-rich fraction from Ishige foliacea on mice with scopolamine-induced memory impairment. A supplementation of 50 and $100 \mathrm{mg} / \mathrm{kg}$ of the phlorotannin-rich fraction for 6 weeks improved the memory impairment symptoms of the rodents, reduced AChE activity in their brain and improved their antioxidant status by decreasing lipid peroxidation levels and increasing glutathione levels and SOD activity. Additionally, the phlorotannin-rich supplementation up-regulated the expression levels of: brain-derived neurotrophic factor (BDNF), tropomyosin receptor kinase B, phosphorylated ERK and cyclic AMP-response element-binding protein (CREB). Therefore, the phlorotannin-rich fraction prevented the memory impairment via regulation of the ERK-CREB-BDNF pathway.

In summary, marine phenolics show potential to prevent or delay the consequences of AD (Table 7 and Figure 2), although it is still a little explored pathology and more in vitro studies need to be undertaken. In addition, the blood-brain barrier represents a challenge for the bioavailability of these compounds, and although there are a few studies confirming that dietary polyphenols may cross the blood-brain barrier [244], it is necessary to confirm the results derived from in vitro models in in vivo studies.

\subsection{Cancer}

Cancer represents a group of diseases related to the abnormal proliferation of any of the different kinds of cells in the body with the potential to spread to other parts of the body [245]. The side effects of antineoplastic drugs and chemotherapy motivate the search for natural products that could be used as new therapeutic agents with more efficacy, specificity and without adverse effects. Among the bioactive compounds present in marine sources, polyphenols have been demonstrated to have potent anticancerogenic activity, which has been recently reviewed [36,246,247]. An association of dietary seaweed intake (gim, miyeok and dashima) with single-nucleotide polymorphisms (SNPs; rs6983267, rs7014346, and rs719725) and colorectal cancer risk in a Korean population has been established.

Colorectal cancer risk and c-MYC rs6983267 association was derived from an analysis of 923 patients and 1846 controls [248]. Furthermore, an inverse association between dietary seaweed intake (gim, miyeok, and dashima) and colorectal cancer risk was observed, suggesting that dietary seaweed may have a positive benefit as a chemotherapeutic or chemopreventive agent for colorectal cancer risk associated with the rs6983267 genotype. Although phenolic compounds are not the only bioactives present in the consumed dietary seaweeds, it is well known that they can contribute to preventing 
or slowing down carcinogenic processes through the different mechanisms that are discussed next (Table 8 and Figure 2).

Polyphenol-rich extracts, as well as isolated phlorotannins and bromophenols, have been extensively described as inhibitors of cancer cell proliferation (Table 8). Aqueous extracts derived from brown Cystoseira crinita showed a significant antiproliferative activity against colon (HCT15) and breast (MCF7) human tumor cell lines, and these were associated with the total phenolic content and the antioxidant activity of the extracts [249]. Likewise, a phlorotannin-rich extract from A. nodosum inhibited the viability of colon carcinoma HT29 cells [250]. Montero et al. [127] evaluated five purified hydroalcoholic extracts of S. muticum from the North Atlantic coast. Their results revealed that the S. muticum sample with the highest level of total phlorotannins presented the highest antiproliferative activity against HT29 adenocarcinoma colon cancer cells ( $\mathrm{IC}_{50} \sim 53-58 \mu \mathrm{g} / \mathrm{mL}$ after $24 \mathrm{~h}$ of treatment). Phlorotannins isolated from the brown alga E. maxima (phloroglucinol, eckol, 7-phloroeckol and 2-phloroeckol) showed antiproliferative activity in HeLa, H157 and MCF7 cancer cell lines, with eckol being the most bioactive tested phlorotannin ( $\mathrm{IC}_{50}<50 \mu \mathrm{g} / \mathrm{mL}$ against HeLa and MCF7 cells after $24 \mathrm{~h}$ of treatment) [251]. Namvar et al. [252] evaluated the antiproliferative activity against five human cancer cell lines (MCF-7, MDA-MB-231, HeLa, HepG2, and HT-29) of seaweed alcoholic extracts of red (Gracillaria corticata), green (Ulva fasciata) and brown (Sargassum ilicifolium). All the extracts showed a dose-dependent antiproliferative activity against all the cancer cell lines, although G. corticata had the greatest inhibition activity against MCF-7 cell line ( $\mathrm{IC}_{50}$ value of $30 \mu \mathrm{g} / \mathrm{mL}$ after 24 of treatment). Lopes-Costa et al. [253] reported that phloroglucinol not only reduced the growth of two colorectal cancer cell lines (HCT116 and HT29), but also intensified the activity of 5-fluorouracil, one of the most commonly used chemotherapeutic drugs to treat colorectal cancer. Two polybrominated diphenyl ethers, 3,4,5-tribromo-2-(2',4'-dibromophenoxy)-phenol and 3,5-dibromo-2-(2', 4'-dibromophe-noxy)-phenol, which were isolated from Dysidea sp., an Indonesian marine sponge, showed antiproliferative activity against PANC-1 cells under glucose-starved conditions. The first bromophenol might act by inhibiting complex II in the mitochondrial electron transport chain [254].

There are many studies focusing on the isolation of seaweed extracts rich in bioactive compounds, along with their chemical characterization and antiproliferative activity. Zenthoefer et al. [24] determined the cytotoxic potential of different extracts from $F$. vesiculosus L. against human pancreatic cancer cells (Panc89 and PancTU1) and the most active extract ( $\mathrm{IC}_{50}$ value of $72 \mu \mathrm{g} / \mathrm{mL}$ against Panc 89 and $77 \mu \mathrm{g} / \mathrm{mL}$ against PancTU1 cells after $72 \mathrm{~h}$ of treatment) was characterized by H-1-NMR spectroscopy, identifying two chemical structures belonging to the phlorotannin group. Bernardini et al. [255] explored the chemical composition of French Polynesian P. pavonica extract by spectrophotometric assays (total phenolic compounds, tannin content and antioxidant activity) and GC-MS analysis to obtain extracts with improved antiproliferative and pro-apoptotic activities against two osteosarcoma cell lines, SaOS-2 and MNNG. Likewise, extracts of three brown marine macroalgae Dictyota dichotoma, P. pavonica and Sargassum vulgare were tested for improving their antioxidant, antimicrobial and cytotoxic activities on human colon carcinoma LS174 cells, human lung carcinoma A549 cells, malignant melanoma FemX cells and chronic myelogenous leukemia K562 cells [256]. Sevimli-Gur and Yesil-Celiktas [155] extracted detached leaves of Posidonia oceanica and Zostera marina with $\mathrm{CO}_{2}$, with ethanol as co-solvent, to obtain phenolic acids with cytotoxic properties on breast, cervix, colon, prostate and neuroblastoma tumor cells. Z. marina extract showed the best $\mathrm{IC}_{50}$ values of 25,20 and $8 \mu \mathrm{g} / \mathrm{mL}$ after $48 \mathrm{~h}$ in neuroblastoma, colon and cervix cancer cell lines, respectively. In the same line, optimized extraction, preliminary chemical characterization, and evaluation of the in vitro antiproliferative activity of phlorotannin-rich fraction from brown seaweed, Cystoseira sedoides, was developed by Abdelhamid et al. with promising results ( $\mathrm{IC}_{50}$ value of $78 \mu \mathrm{g} / \mathrm{mL}$ after $72 \mathrm{~h}$ of treatment) [257]. Another recent example was carried out by Abu-Khudir et al. [258], who evaluated the antioxidant, antimicrobial and cytotoxic effect of crude extracts of the Egyptian brown seaweeds, Sargassum linearifolium and Cystoseira crinita, against a group of cancer cells-the latter with a strong cytotoxic activity against MCF-7 cells $\left(\mathrm{IC}_{50}\right.$ value of $18 \mu \mathrm{g} / \mathrm{mL}$ after $48 \mathrm{~h}$ ). They observed an increased mRNA and protein expression of the pro-apoptotic 
Bax and the marker of autophagy Beclin-1, a reduced expression of the anti-apoptotic Bcl-2, as well as revealed the ability of these extracts to induce apoptosis and autophagy in MCF-7 cells. Finally, Premarathana et al. [259] carried out a preliminary screening of the cytoxicity activity on a mouse fibroblast (L929) cell line of twenty-three different seaweed species in Sri Lanka (Table 8). Crude extracts of brown and red seaweed species showed high mortality rate compared to green seaweeds and Jania adherens showed a remarkable cytotoxic effect on L929 cell line (51\% cell viability compared with control after $24 \mathrm{~h}$ ).

Activation of apoptosis, programmed cell death, is an important target in cancer therapy. Namvar et al. [252] demonstrated the ability of an alcoholic extract from the red seaweed Gracillaria corticata to induce apoptosis in human breast cancer cells (MCF-7), as well as Sargassum linearifolium and Cystoseira crinite, as already mentioned [258]. Dieckol suppressed ovarian cancer cell (SKOV3) growth by inducing caspase-dependent apoptosis via ROS production and the regulation of Akt and p38 signaling pathways [260]. A phlorotannin-rich extract from E. cava, mainly composed of dieckol, was assessed in terms of cisplatin responsiveness, and in its effects on A2780 and SKOV3 ovarian cancer cell lines, as well as on a SKOV3-bearing mouse model [261]. They found that dieckol may improve the efficacy of platinum drugs for ovarian cancer, by enhancing cancer cell apoptosis via the ROS/Akt/NFKB pathway and reducing nephrotoxicity. Phlorofucofuroeckol A, a phlorotannin present in the brown alga E. bicyclis, exhibited antiproliferative and proapoptotic properties in human cancer cells (LoVo, HT-29, SW480 and HCT116) by activating the transcription factor 3 (ATF3)-mediated pathway in human colorectal cancer cells [262]. Park et al. [263] showed that an ethanolic extract of Hizikia fusiforme decreased the viability of B16F10 mouse melanoma cells and induced apoptosis through activation of extrinsic and intrinsic apoptotic pathways and ROS-dependent inhibition of the PI3K/Akt signaling pathway. No chemical characterization of the tested extract was carried out, and other bioactive compounds present in the extract, apart from polyphenols, could have contributed to the observed effect.

Metastasis is an important cellular marker of cancer progression and has been associated with an increase in the activity of matrix metalloproteinases (MMPs), which are needed to degrade connective tissues. A polyphenol-rich extract of E. cava showed a potent inhibitory effect on the metastatic activity of A549 human lung carcinoma cells, including the suppressions of migration and invasion. This polyphenol-rich extract down-regulated MMP-2 activity through the inhibition of the PI3K/Akt signaling pathway [264]. Phloroglucinol, isolated from the brown alga E. cava, diminished the population of breast cancer cell lines (MCF7, SKBR3 and BT549) in tumors, by inhibiting KRAS and its downstream PI3K/Akt and RAF-1/ERK signaling pathways. Furthermore, phloroglucinol increased sensitization of breast cancer cells to conventional therapy (chemotherapy and ionizing radiation) [265]. The same research group also confirmed the effectiveness of phloroglucinol against metastasis of breast cancer through downregulation of SLUG by the inhibition of PI3K/Akt and RAS/RAF-1/ERK signaling pathways [266]. Phloroglucinol was also effective against metastasis of breast cancer cells, drastically suppressing their metastatic ability in lungs, and extending the survival time of mice. In agreement with in vitro data, phloroglucinol also exhibited breast anticancer activity at $25 \mathrm{mg} / \mathrm{kg} \mathrm{bw}$, either by decreasing tumor growth or by suppressing the metastatic ability of breast cancer cells that spread to the lungs, contributing in both cases to an increase in survival time in mice [266].

Angiogenesis has a crucial role in tumor growth and metastasis and is also related to an aggressive tumor phenotype where vascular endothelial growth factor (VEGF) is the most important component. Qi et al. [267] demonstrated that bis(2,3-dibromo-4,5-dihydroxybenzyl) ether treatment repressed angiogenesis in human endothelial cells (HUVECs) and in zebrafish embryos via inhibiting the VEGF signal systems. Dieckol modulated the expression of key molecules that regulate apoptosis, inflammation, invasion, and angiogenesis. Daily administration of dieckol isolated from E. cava ( $40 \mathrm{mg} / \mathrm{kg}$ for 15 weeks) to rats with N-nitrosodiethylamine(NDEA)-induced hepatogenesis regulated xenobiotic-metabolizing enzymes and by modulating Bcl-2 family proteins induced apoptosis via the regulation of mitochondrial release of cytochrome $\mathrm{c}$ and the activation of caspases [268]. 
Anti-inflammatory activity of dieckol was associated with inhibition of the nuclear factor-kappa B (NF-KB) and COX2. In addition, dieckol treatment inhibited invasion by decreasing proliferating cell nuclear antigen (PCNA) expression and angiogenesis by changing MMP-2 and MMP-9 activities and VEGF expression. Li et al. [269] found that dieckol exhibited antiangiogenic activity by inhibiting the proliferation and migration of EA.hy926 cells through mitogen-activated protein kinase (MAPK), extra-cellular signal regulated kinase (ERK) and p38 signaling pathways (Table 8).

The antioxidant activity of phlorotannins and bromophenols offers a complementary mechanism to mitigate cancerous processes as observed in a few studies already discussed. Zhen et al. [270] associated the protective effects of eckol against PM2.5-induced cell damage on human HaCaT keratinocytes with a reduced ROS generation, ensuring the stability of molecules, and maintaining a steady mitochondrial state. In addition, eckol protected cells from apoptosis by inhibiting the MAPK signaling pathway. An interesting study carried out by Zhang et al. [271] investigated the in vivo antitumor effect and the mechanisms involved in a sarcoma 180 (S180) xenograft-bearing animal model supplemented with low-dose $(0.25 \mathrm{mg} / \mathrm{kg})$, middle-dose $(0.5 \mathrm{mg} / \mathrm{kg})$ and high-dose $(1.0 \mathrm{mg} / \mathrm{kg})$ of eckol. The pro-apoptosis and antiproliferation activities of eckol were manifested by the increased TUNEL-positive apoptotic cells, the upregulated Caspase- 3 and Caspase- 9 expression, and the downregulated expression of Bcl-2, Bax, EGFR and p-EGFR in eckol-treated transplanted S180 tumors. Eckol stimulated the mononuclear phagocytic system, recruited and activated DCs, promoted the tumor-specific Th1 responses, increased the CD4+/CD8+ T lymphocyte ratio, and enhanced cytotoxic $\mathrm{T}$ lymphocyte responses in the eckol-treated animals; this suggests its potent stimulatory property on innate and adaptive immune responses.

Despite the promising anticancer activity described for marine phenolics, no human studies have been conducted to directly confirm their efficacy against cancer. DNA damage results in an increased rate of genetic mutations that often lead to the development of cancer [272]. The anticancerogenic activity of seaweeds was indirectly verified in a clinical trial. A modest improvement in DNA damage was observed in an obese group after consuming $100 \mathrm{mg} /$ day for 8 weeks of a (poly)phenol-rich extract of the brown algae A. nodosum.

In summary, there are many in vitro studies-in addition to in vivo studies-using animal models that demonstrate the potential of marine polyphenols to block carcinogenic mechanisms (Table 8 and Figure 2). Given the prevalence of this pathology, the next step would be to test their efficacy in human trials. 
Table 8. Effect of marine phenolics on the prevention of cancer.

\begin{tabular}{|c|c|c|c|}
\hline Compounds/Marine Source & Test Model & Outcome & Ref. \\
\hline Dietary seaweed intake (gim, miyeok, and dashima) & In vivo: 923 colorectal cancer patients and 1846 controls & $\begin{array}{l}\text { Association between c-MYC rs6983267 and colorectal cancer risk } \\
\text { Inverse association between dietary seaweed intake and colorectal } \\
\text { cancer risk }\end{array}$ & [248] \\
\hline Aqueous extract derived from brown Cystoseira crinita & In vitro: HCT15 and MCF7 cells ( $25-250 \mu \mathrm{g} / \mathrm{mL}$ for extracts) & $\begin{array}{l}\text { Antiproliferative activity ( } \mathrm{IC}_{50} \text { of } 10.5-26.4 \mu \mathrm{g} / \mathrm{mL} \text { on } \mathrm{HCT} 15 \text { and } \\
17.9-29.5 \mu \mathrm{g} / \mathrm{mL} \text { for } 24 \mathrm{~h} \text { ) associated with phenolic content and } \\
\text { antioxidant activity }\end{array}$ & [249] \\
\hline Phlorotannin-rich extract from A. nodosum & In vitro: HT29 cells (100-500 $\mu \mathrm{g} / \mathrm{mL}$ for extracts) & Antiproliferative activity & [250] \\
\hline Ethanolic extract from S. muticum rich in phlorotannins & In vitro: HT29 cells $(12.5-100 \mu \mathrm{g} / \mathrm{mL}$ for extracts) & $\begin{array}{l}\text { Antiproliferative activity ( }\left(\mathrm{IC}_{50} \text { of } \sim 53.5-57.9,55.0-57.8 \text { and }\right. \\
59.4-74.0 \mathrm{\mu g} / \mathrm{L} \text { for } 24,48 \text { and } 72 \mathrm{~h} \text { of treatment of } S . \text { muticum extracts) }\end{array}$ & [127] \\
\hline $\begin{array}{l}\text { Phlorotannins isolated from Ecklonia maxima (phloroglucinol, eckol, } \\
\text { 7-phloroeckol and 2-phloroeckol) }\end{array}$ & In vitro: HeLa, H157 and MCF7 cells ( $6.25-500 \mu \mathrm{g} / \mathrm{mL}$ for phenol) & $\begin{array}{l}\text { Antiproliferative activity: eckol was the most active of all the tested } \\
\text { phlorotannins against HeLa and MCF7 cells after } 24 \text { of } \\
\text { treatment }\left(\mathrm{IC}_{50}<50 \mu \mathrm{g} / \mathrm{mL}\right)\end{array}$ & [251] \\
\hline $\begin{array}{l}\text { Alcoholic extract from red (Gracillaria corticata), green (Ulva fasciata) } \\
\text { and brown (Sargassum ilicifolium) seaweeds }\end{array}$ & $\begin{array}{l}\text { In vitro: MCF-7, MDA-MB-231, HeLa, HepG2 and HT-29 cells } \\
\text { (15-300 } \mu \mathrm{g} / \mathrm{mL} \text { for extracts) }\end{array}$ & $\begin{array}{l}\text { Antiproliferative activity: G. corticata extract had the greatest activity } \\
\text { against MCF-7 cells (IC } 50 \text { of } 30,37,53,102 \text { and } 250 \mu \mathrm{g} / \mathrm{mL} \text { on MCF-7, } \\
\text { HeLa, MDA-MB-231, HepG2 and HT-29 cells, respectively, after } 24 \mathrm{~h} \\
\text { of treatment) } \\
\text { G. corticata extract induced the apoptosis in human breast cancer cells }\end{array}$ & [252] \\
\hline Phloroglucinol & In vitro: HCT116 and HT29 cells (10-300 $\mu \mathrm{M}$ of phenol) & $\begin{array}{l}\text { Antiproliferative activity } \\
\text { Intensified the 5-fluorouracil activity }\end{array}$ & [253] \\
\hline $\begin{array}{l}\text { 3,4,5-Tribromo-2-(2',4'-dibromophenoxy)-phenol (1) and } \\
\text { 3,5-dibromo-2-(2', } 4^{\prime} \text {-dibromophenoxy)-phenol (2) isolated from } \\
\text { marine sponge Dysidea sp. }\end{array}$ & $\begin{array}{l}\text { In vitro: PANC-1 cells under glucose-starved conditions (1-100 } \mu \mathrm{M} \\
\text { of phenol) }\end{array}$ & $\begin{array}{c}\text { Antiproliferative activity }\left(\mathrm{IC}_{50} \text { values of } 2.1 \text { and } 3.8 \mu \mathrm{M} \text { for } 1 \text { and 2, }\right. \\
\text { respectively, after } 12 \mathrm{~h}) \\
\text { Inhibition of the complex II in the mitochondrial electron } \\
\text { transport chain }\end{array}$ & [254] \\
\hline Different extracts from $F$. vesiculosus $L$. rich in phlorotannins & $\begin{array}{l}\text { In vitro: Panc } 89 \text { and PancTU1 cells }(0.8-500 \mu \mathrm{g} / \mathrm{mL} \text { for crude extracts } \\
\text { and } 0.16-200 \mu \mathrm{g} / \mathrm{mL} \text { for fractions })\end{array}$ & $\begin{array}{l}\text { Antiproliferative activity ( } \mathrm{IC}_{50} \text { of } 72 \mu \mathrm{g} / \mathrm{mL} \text { against Panc } 89 \text { and of } \\
77 \mu \mathrm{g} / \mathrm{mL} \text { against PancTU1 cells after } 72 \mathrm{~h} \text { of treatment for the most } \\
\text { active crude extract) }\end{array}$ & [24] \\
\hline Extract from P. pavonica & In vitro: SaOS- 2 and MNNG cells $(0.5-2.5 \mu \mathrm{g} / \mathrm{mL}$ for extract $)$ & $\begin{array}{l}\text { Antiproliferative }\left(\mathrm{IC}_{50} \text { value of } 152.2 \mathrm{and} 87.75 \mu \mathrm{g} / \mathrm{mL} \text { for SaOS-2 }\right. \\
\text { and MNNG cells, respectively, after } 24 \mathrm{~h} \text { ) and pro-apoptotic activities }\end{array}$ & [255] \\
\hline $\begin{array}{c}\text { Extracts of three brown marine macroalgae Dictyota dichotoma, } \\
\text { Padaina pavonia and Sargassum vulgare }\end{array}$ & In vitro: LS174, A549, FemX, K562 cells (12.5-200 $\mu \mathrm{g} / \mathrm{mL}$ for extract) & $\begin{array}{l}\text { Characterization of the cytotoxic activity } \\
\text { D. dichotoma showed the strongest cytotoxic activity of all the tested } \\
\text { extracts ( } \mathrm{IC}_{50} \text { values ranging from } 9.76 \text { to } 50.96 \mu \mathrm{g} / \mathrm{mL} \text { after } 72 \mathrm{~h} \text { ) }\end{array}$ & [256] \\
\hline Extracts from detached leaves of Posidonia oceanica and Zostera marina & $\begin{array}{l}\text { In vitro: MCF-7, MDA-MB-231, SK-BR-3, HT-29, HeLa, PC-3 and } \\
\text { Neuro 2A cells, as well as African green monkey kidney (VERO) } \\
\text { (6.25-100 } \mu \mathrm{g} / \mathrm{mL} \text { for extract) }\end{array}$ & $\begin{array}{l}\text { Characterization of the cytotoxic activity } \\
\text { Z. marina extract showed the best I } \mathrm{I}_{50} \text { values of } 25,20 \text { and } 8 \mu \mathrm{g} / \mathrm{mL} \\
\text { after } 48 \mathrm{~h} \text { in neuroblastoma, colon and cervix cancer cell } \\
\text { lines, respectively }\end{array}$ & [155] \\
\hline Phlorotannin-rich fraction from Cystoseira sedoides & In vitro: MCF-7 cells $(10-200 \mu \mathrm{g} / \mathrm{mL}$ for extract) & $\begin{array}{l}\text { Characterization of the antiproliferative activity ( } \mathrm{IC}_{50} \text { value of } \\
\qquad 78 \mu \mathrm{g} / \mathrm{mL} \text { after } 72 \mathrm{~h} \text { ) }\end{array}$ & [257] \\
\hline $\begin{array}{l}\text { Crude extracts from two Egyptian brown seaweeds, Sargassum } \\
\text { linearifolium and Cystoseira crinita }\end{array}$ & $\begin{array}{l}\text { In vitro: a panel of cancer cells such as MCF-7 cells, among others } \\
(0.01-2000 \mu \mathrm{g} / \mathrm{mL} \text { for extract })\end{array}$ & $\begin{array}{c}\text { Characterization of the cytotoxic activity. C. crinite cold methanolic } \\
\text { extract showed a strong cytotoxic activity against MCF-7 cells (IC } \mathrm{IC}_{50} \\
\text { value of } 18 \mu \mathrm{g} / \mathrm{mL} \text { after } 48 \mathrm{~h}) \\
\text { Induced the apoptosis and autophagy in MCF-7 cells }\end{array}$ & [258] \\
\hline
\end{tabular}


Table 8. Cont.

\begin{tabular}{|c|c|c|c|}
\hline Compounds/Marine Source & Test Model & Outcome & Ref. \\
\hline Aqueous seaweed extracts of 23 different species in Sri Lanka & In vitro: L929 cells $(10-100 \mu \mathrm{g} / \mathrm{mL}$ for extract) & $\begin{array}{c}\text { Antiproliferative activity } \\
\text { Crude extracts of brown and red seaweeds species have shown high } \\
\text { mortality rate compared to green seaweeds } \\
\text { Jania adherens showed a remarkable cytotoxic effect on L929 cell line } \\
(51 \% \text { cell viability compared with control after } 24 \mathrm{~h})\end{array}$ & [259] \\
\hline Ethanolic extract from E. cava whose main component was dieckol & In vitro: A2780 and SKOV3 cells & $\begin{array}{c}\text { Cytotoxic effects on } \mathrm{A} 2780 \text { and } \mathrm{SKOV} 3 \text { ovarian cancer cells }\left(\mathrm{IC}_{50}\right. \\
\text { ranging from } 84 \text { to } 100 \mathrm{\mu g} / \mathrm{mL} \text { for extract and from } 77 \text { to } 169 \mu \mathrm{M} \text { for } \\
\text { phenols, with dieckol being the most active of all, after } 24 \mathrm{~h}) \\
\text { Induced the apoptosis on SKOV3 cells via Akt and p38 } \\
\text { signaling pathways }\end{array}$ & [260] \\
\hline Phlorotannin-rich extract from E. cava rich in dieckol & $\begin{array}{l}\text { In vitro: A2780 and SKOV3 cells }(50-100 \mu \mathrm{g} / \mathrm{mL}) \\
\text { In vivo: SKOV3-bearing mouse model ( } 75 \text { and } 150 \mathrm{mg} / \mathrm{kg} \mathrm{bw} \text { for } \\
\text { extract and } 50 \text { and } 100 \mathrm{mg} / \mathrm{kg} \text { bw for dieckol was given orally three } \\
\text { times/week for } 4 \text { weeks) }\end{array}$ & $\begin{array}{l}\text { Phlorotannin-rich extract may improve the efficacy of cisplatin for } \\
\text { ovarian cancer by enhancing cancer cell apoptosis via the } \\
\text { ROS/Akt/NFkB pathway }\end{array}$ & [261] \\
\hline Phlorofucofuroeckol A present in E. bicyclis & $\begin{array}{l}\text { In vitro: LoVo, HT-29, SW480 and HCT116 cells (25-100 } \mu \mathrm{M} \\
\text { of phenol) }\end{array}$ & $\begin{array}{c}\text { Antiproliferative and pro-apoptotic properties } \\
\text { Induced the apoptosis on colorectal cancer cells by ATF3 } \\
\text { signaling pathway }\end{array}$ & [262] \\
\hline Ethanolic extract of $H$. fusiforme & In vitro: B16F10 cells ( $25-400 \mu \mathrm{g} / \mathrm{mL}$ of extract) & $\begin{array}{c}\text { Cytotoxic activity } \\
\text { Induced the apoptosis through activation of extrinsic and intrinsic } \\
\text { apoptotic pathways and ROS-dependent inhibition of the PI3K/Akt } \\
\text { signaling pathway }\end{array}$ & [263] \\
\hline Phlorotannin-rich extract from E. cava rich in phenolic compounds & In vitro: A549 cells (12.5-50 $\mu \mathrm{g} / \mathrm{mL}$ of extract) & $\begin{array}{c}\text { Inhibition of metastatic activity including suppression of migration } \\
\text { and invasion } \\
\text { Down-regulated the MMP- } 2 \text { activity via PI3K/Akt }\end{array}$ & [264] \\
\hline Phloroglucinol isolated from E. cava & $\begin{array}{c}\text { In vitro: MCF7, SKBR3 and BT549 cells (10-100 } \mu \mathrm{M} \text { of phenol) } \\
\text { In vivo: MDA-MB231 breast cancer cells implanted into mammary } \\
\text { fat pads of NOD-scid gamma (NSG) mice, treated with } \\
\text { phloroglucinol } 4 \text { times on alternate days ( } 25 \mathrm{mg} / \mathrm{kg} \text { bw by } \\
\text { intratumoral injections) }\end{array}$ & $\begin{array}{l}\text { Antiproliferative effect by KRAS inhibition and its downstream } \\
\text { PI3K/Akt and RAF-1/ERK signaling pathways } \\
\text { Increased the sensitization of breast cancer cells to } \\
\text { conventional therapy }\end{array}$ & [265] \\
\hline Phloroglucinol isolated from E. cava & $\begin{array}{l}\text { In vitro: BT549 and MDA-MB-231 cells ( } 10-100 \mu \mathrm{M} \text { of phenol) } \\
\text { In vivo: GFP-labeled metastatic MDA-MB231 cells transplanted into } \\
\text { mammary fat pads of NSG mice, treated with phloroglucinol } 4 \text { times } \\
\text { on alternate days ( } 25 \mathrm{mg} / \mathrm{kg} \text { bw by intraperitoneal injection) }\end{array}$ & $\begin{array}{l}\text { Inhibited the metastatic ability of breast cancer cells } \\
\text { Decreased the expression of SLUG, EMT master regulator through } \\
\text { inhibition of PI3K/Akt and RasRaf- } 1 \text { ERK } \\
\text { Inhibited the in vivo metastatic ability of breast cancer cells }\end{array}$ & [266] \\
\hline Bis(2,3-dibromo-4,5-dihydroxybenzyl) ether & $\begin{array}{l}\text { In vitro: HUVEC cells }(12.5-50 \mu \mathrm{M} \text { of phenol) } \\
\text { In vivo: Zebrafish embryos model }(6.25-25 \mu \mathrm{M} \text { of phenol) }\end{array}$ & $\begin{array}{l}\text { Repressed the angiogenesis in both in vitro and in vivo models by } \\
\text { inhibiting the VEGF signal systems }\end{array}$ & [267] \\
\hline Dieckol from E. cava & $\begin{array}{l}\text { In vivo: } N \text {-nitrosodiethylamime-induced hepatocarcinogenesis rats } \\
(40 \mathrm{mg} / \mathrm{kg} \text { bw/day for } 15 \text { weeks administered orally) }\end{array}$ & $\begin{array}{c}\text { Regulated the xenobiotic-metabolizing enzymes } \\
\text { Induced the apoptosis by mitochondrial pathway } \\
\text { Inhibited the invasion by decreasing PCNA expression } \\
\text { Inhibited the angiogenesis by changing MMP-2 and MMP-9 activity } \\
\text { and VEGF expression } \\
\text { Anti-inflammatory activity by inhibiting NF-kB and COX2 }\end{array}$ & [268] \\
\hline Dieckol & In vitro: EA.hy926 cells (10-100 $\mu \mathrm{M}$ of phenol) & $\begin{array}{l}\text { Antiangiogenic activity by inhibiting the proliferation and migration } \\
\text { of cells through MAPK, ERK and p38 signaling pathways }\end{array}$ & [269] \\
\hline
\end{tabular}


Table 8. Cont

\begin{tabular}{|c|c|c|c|}
\hline Compounds/Marine Source & Test Model & Outcome & Ref. \\
\hline Eckol & $\begin{array}{l}\text { In vitro: on human HaCaT keratinocytes against PM2.5-induced cell } \\
\text { damage ( } 30 \mu \mathrm{M} \text { of phenol for } 17 \text { days) }\end{array}$ & $\begin{array}{c}\text { Decreased the ROS generation } \\
\text { Protected the cells from apoptosis by inhibiting MAPK } \\
\text { signaling pathway }\end{array}$ & [270] \\
\hline Eckol & $\begin{array}{l}\text { In vivo: sarcoma } 180 \text { (S180) xenograft-bearing animal model } \\
\text { supplemented with low dose }(0.25 \mathrm{mg} / \mathrm{kg} \text { bw), middle dose } \\
(0.5 \mathrm{mg} / \mathrm{kg} \mathrm{bw}) \text { and high dose }(1.0 \mathrm{mg} / \mathrm{kg} \mathrm{bw}) \text { of phenol } \\
\text { administered orally }\end{array}$ & $\begin{array}{l}\text { Proapoptotic and antiproliferative activities by improving the } \\
\text { immune response }\end{array}$ & [271] \\
\hline Polyphenol-rich extract from $A$. nodosum & $\begin{array}{l}\text { In vivo: } 80 \text { overweight or obese population }(100 \mathrm{mg} / \text { day of extract } \\
\text { for } 8 \text { weeks) }\end{array}$ & Improvements in DNA damage in the obese subset & [30] \\
\hline
\end{tabular}

ROS:reactive oxygen species; Akt: protein kinase B; NFkB: nuclear factor kappa B; ATF3: transcription factor 3; MMP: metalloproteinase; PI3k: phosphoinositide 3-kinase; VEGF: vascular endothelial growth factor; PCNA: proliferating cell nuclear antigen; COX-2: cyclooxygenase-2; MAPK: mitogen-activated protein kinase; ERK: extracellular signal-regulated kinase; DNA: deoxyribonucleic acid. 


\subsection{Human Gut Microbiota}

The human intestine contains an intricate ecological community of dwelling bacteria, referred to as gut microbiota, which plays a pivotal role in host homeostasis. Multiple factors could interfere with this delicate balance, including genetics, age, antibiotics, as well as environmental factors, particularly diet, thus causing a disruption of microbiota equilibrium (dysbiosis). Growing evidence supports the involvement of gut microbiota dysbiosis in gastrointestinal and extra-intestinal cardiometabolic diseases, namely obesity and diabetes [273]. Even though, seaweeds and microalgae are excellent sources of prebiotics such as fucoidans, alginates, carrageenans and exopolysaccharides that can be partially fermented. We will focus next on marine polyphenol studies that explore their influence on gut microbiota (Table 9).

Table 9. Effect of marine phenolics in human gut microbiota.

\begin{tabular}{|c|c|c|c|}
\hline Compounds/Marine Source & Test Model & Outcome & Ref. \\
\hline Food supplement from Kappaphycus alvarezii & $\begin{array}{l}\text { In vivo: rats fed for } 8 \text { weeks on } \\
\text { high-carbohydrate, high-fat diet, alone or } \\
\text { supplemented with } 5 \%(w / w) \text { algae }\end{array}$ & $\begin{array}{c}\text { Improved the cardiovascular, liver and metabolic } \\
\text { biomarkers in obese rats } \\
\text { Modulated the balance between Firmicutes and } \\
\text { Bacteroidetes in the gut }\end{array}$ & [226] \\
\hline $\begin{array}{l}\text { Polyphenol-rich extracts from brown } \\
\text { macroalgae L. trabeculate }\end{array}$ & $\begin{array}{l}\text { In vivo: high-fat diet and STZ-induced } \\
\text { diabetic rats }(200 \mathrm{mg} / \mathrm{kg} / \text { day bw of phenol } \\
\text { for } 4 \text { weeks by gavage })\end{array}$ & $\begin{array}{l}\text { Attenuated the hyperglycemia in diabetic rats } \\
\text { Increased the short-chain fatty acid contents in } \\
\text { fecal samples } \\
\text { Enhanced the abundance of Bacteroidetes, Odoribacter } \\
\text { and Muribaculum } \\
\text { Decreased the abundance of Proteobacteria as well as } \\
\text { Firmicutes/Bacteroidetes ratio }\end{array}$ & [103] \\
\hline $\begin{array}{l}\text { Water-ethanolic extract of green macroalgae } \\
\text { Enteromorpha prolifera rich in flavonoids }\end{array}$ & $\begin{array}{c}\text { In vivo: STZ-induced diabetic rats } \\
(150 \mathrm{mg} / \mathrm{kg} / \text { day bw of phenol for } 4 \text { weeks } \\
\text { by gavage })\end{array}$ & $\begin{array}{l}\text { Showed the antidiabetic activity on diabetic mice } \\
\text { Modulated the balance between Firmicutes and } \\
\text { Bacteroidetes in the gut and increased the abundance } \\
\text { of the Lachnospiraceae and Alisties bacteria involved in } \\
\text { the prevention of T2DM }\end{array}$ & [191] \\
\hline
\end{tabular}

Several studies showed that polyphenol-rich extracts had a positive effect on regulating the dysbiosis of the microbial ecology in rats. The red seaweed $K$. alvarezii tested as a food supplement demonstrated its capacity to improve cardiovascular, liver, and metabolic biomarkers in obese rats. Kappaphycus also modulated the balance between Firmicutes and Bacteroidetes in the gut, which could serve as a potential mechanism to reverse MetS through selective inhibition of obesogenic gut bacteria and promote healthy gut bacteria [226]. Polyphenol-rich extracts from L. trabeculate attenuated hyperglycemia in high-fat diet and STZ-induced diabetic rats [103], as aforementioned. Higher Bacteroidetes, Odoribacter and Muribaculum abundances, lower Proteobacteria abundances, as well as a reduced Firmicutes/Bacteroidetes ratio, were observed in the polyphenol supplemented group in comparison with untreated diabetic rats. In addition, rats supplemented with polyphenols showed higher amounts of short-chain fatty acids in fecal samples compared with the un-supplemented diabetic group. In their study discussed above, Yan et al. [191] showed the antidiabetic activity of a water-ethanolic extract of the green macroalgae E. prolifera. This extract, which was rich in flavonoids, significantly modulated the balance between Firmicutes and Bacteroidetes and increased the abundance of the Lachnospiraceae and Alisties bacteria involved in the prevention of T2DM. Guo et al. [274] demonstrated the efficacy of administering $50 \mathrm{mg} / \mathrm{kg} /$ day for 8 weeks of a Nitzschia laevis extract in preventing obesity in mice fed with a high-fat diet. This extract protected the gut epithelium and positively reshaped the gut microbiota composition against the damaging effect of a high-fat diet. The Nitzschia laevis extract was a mixture of bioactive compounds, including carotenoids and polyphenols; therefore, the specific functional ingredient(s) of this product and their potential synergistic effect (if any) are yet to be defined. 


\subsection{Infectious Diseases}

Apart from the dietary and lifestyle-related diseases, marine phenolics are involved in the prevention of other pathological processes due to their multiple bioactivities (enzyme inhibitory effect and antimicrobial, antiviral, anticancer, antidiabetic, antioxidant, and anti-inflammatory activities, among others). Special attention should be focused on infectious diseases caused by bacteria, viruses, and fungi that continue to grow despite the development of antibiotics in the 1940s. In the western world, the issue is not the availability of antimicrobial treatments, but the developed immunity of microorganisms to pharmaceutical drugs and disinfectants. Natural products are an important source of new drugs. Approximately 80 antibacterial drugs, which were approved from 1981 to 2014, either were natural products or directly derived from them [275]. Therefore, bacterial and fungal infections and the emerging multidrug resistance are driving interest into fighting these microorganisms with natural products, which have generally been considered complementary to pharmacological therapies, and marine phenolics can be an appealing alternative (Table 10).

Lopes et al. [131] found that in vitro phlorotannin purified extracts from ten brown algal species, collected along the Portuguese west coast, were shown to be less effective against fungi and Gram-negative bacteria than Gram-positive bacteria. F. spiralis and C. nodicaulis were the most effective species (MIC $=3.9 \mathrm{mg} / \mathrm{mL}$ ), followed by C. usneoides, $S$. vulgare (MIC $=7.8 \mathrm{mg} / \mathrm{mL}$ ), and C. tamariscifolia (MIC $=31.3 \mathrm{mg} / \mathrm{mL}$ ) against Trichophyton rubrum. Likewise, C. nodicaulis extracts were the most effective against $C$. albicans (MIC $=7.8 \mathrm{mg} / \mathrm{mL}$ ). Cystoseira $\mathrm{sp}$, and F. spiralis were the most active against Staphylococcus and against M. luteus (with minimum inhibitory concentration (MIC) values of $2.0-3.9 \mathrm{mg} / \mathrm{mL}$ ). These effects could be related to their content in phlorotannins of the purified extracts, although their microbial activity is not truly relevant considering the MIC values. Rajauria et al. [276] reported that aqueous methanolic extracts isolated from the Irish brown seaweed H. elongata showed the highest antimicrobial activity against the Gram-positive bacteria L. monocytogenes and E. faecalis, and against the Gram-negative P. aeruginosa and S. abony. These authors related the antimicrobial activity with their polyphenol content and antioxidant activity.

Steele et al. [83] reported a "pseudo-induction" of plant phenolic acids (p-hydroxybenzoic acid, $\mathrm{p}$-coumaric acid and vanillin) caused by changing the pattern of rearrangements of resources in plant tissues as a response of turtlegrass Thalassia testudinum to infection with Labyrinthula sp. The eelgrass Zostera marina possesses defensive mechanisms possibly associated with surface metabolites for surface protection and fouling control against marine epiphytic yeasts. The major constituents of eelgrass leaf surfaces and whole tissues were rosmarinic acid, p-coumaric acid, caffeic acid, ferulic acid, zosteric acid, apigenin-7-sulfate, luteolin-7-sulfate, diosmetin-7-sulfate (the most abundant) and their desulfated forms, as well as kaempferol-7, $4^{\prime}$-dimethylether-3-O-sulfate. Papazian et al. [5] confirmed the existence of a selective chemical defense system in eelgrass which involved surface-associated phenolics and fatty acids to control growth and settlement of the microfouling yeasts Cryptococcus fonsecae and Debaryomyces hansenii. In addition, the antioxidant and cytotoxic capacities of desulfated flavonoids were enhanced compared to their sulfated compounds [5].

Free phenolic acid extracts from Nannochloropsis sp. (chlorogenic, gallic, protocatechuic, hydroxybenzoic, syringic, vanillic and ferulic acids) and Spirulina sp. (chlorogenic, hydroxybenzoic, protocatechuic and gallic acids) were efficient in reducing the mycelial growth rates of Fusarium. Moreover, synthetic mixtures of phenolic acids from both microalgae were less efficient than the natural extracts $\left(\mathrm{EC}_{50}\right.$ values of $49.6 \mu \mathrm{g} / \mathrm{mL}$ and $33.9 \mu \mathrm{g} / \mathrm{mL}$ for Nannochloropsis and Spirulina phenolic acid extracts, respectively) to inhibit fungal growth, indicating that no purification is required [27]. Maadame et al. [50] evaluated the antimicrobial activities of nine marine microalgae from Moroccan coastlines (Nannochloropsis gaditana, Dunaliella salina, Dunaliella sp., Phaeodactylum tricornutum, Isochrysis sp., Navicula sp., Chaeotoceros sp., Chlorella sp. and Tetraselmis sp.). Ethanolic extracts of the selected microalgae were evaluated against bacteria (Escherichia coli, Pseudomonas aeruginosa and Staphylococcus aureus), yeast (Candida albicans) and fungus (Aspergillus niger). Tetraselmis sp. and Nannochloropsis gaditana extracts exhibited an inhibitory effect against the three types of bacteria while 
extracts from Dunaliella salina, Phaeodactylum tricornutum and Isochrysis sp. showed inhibitory activity only against the first two strains. Tetraselmis sp. was the most active of all the marine microalgae tested with MIC of 2.6 to $3.0 \mu \mathrm{g} / \mathrm{mL}$ of extract, indicative of high antimicrobial activity. All the tested extracts modestly inhibited the growth of Candida albicans, although N. gaditana showed the highest activity with MIC of $4.0 \mathrm{mg} / \mathrm{mL}$ of extract. None of them were able to inhibit Aspergillus niger. The observed antimicrobial activities were linked to fatty acid, carotenoid, and phenolic content of the extracts.

Sushanth and Rajashekhar [59] found that the extracts of four marine microalgae (Chaetoceros calcitrans, Skeletonema costatum, Chroococcus turgidus and Nannochloropsis oceanica) possessed effective inhibitory activity against Staphylococcus aureus, Streptococcus pyogenes and Bacillus subtilis. A hexane extract of Chroococcus turgidus showed significant inhibition activity against Escherichia coli, followed by an ethanol extract of Skeletonema costatum against Streptococcus pyogenes. Antifungal activity was found only in Skeletonema costatum and Chroococcus turgidus (Table 10).

Recently, Besednova et al. [277] have reviewed the activity of marine algal metabolites as promising therapeutics for the prevention and treatment of human immunodeficiency virus infection and acquired immunedeficiency syndrome (HIV/AIDS), discussing some studies focused on phlorotannins. Diphlorethohydroxycarmalol isolated from Ishige okamurae exhibited inhibitory effects on HIV-1 reverse transcriptase (RT) and integrase ( $\mathrm{IC}_{50}$ values of $9.1 \mu \mathrm{M}$ and $25.2 \mu \mathrm{M}$, respectively), although it did not show an inhibitory activity against HIV-1 protease [278]. Specifically, 6,6'-bieckol isolated from E. cava showed a strong inhibition against HIV-1 induced syncytia formation, lytic effects and viral p24 antigen production [279]. In addition, 6,6'-bieckol selectively inhibited the activity of HIV-1 RT enzyme and HIV-1 entry. Another compound of this group, 8, $4^{\prime \prime}$-dieckol isolated from E. cava [280], also showed similar results as those reported by Artan et al. [279]. Therefore, there is enough evidence to support the antimicrobial activity of marine phenolics, which encourages the research community to continue exploring their application through the development of animal and human studies. 
Table 10. Effect of marine phenolics on the prevention of infectious diseases.

\begin{tabular}{|c|c|c|c|}
\hline Compounds/Marine Source & Test Model & Outcome & Ref. \\
\hline $\begin{array}{l}\text { Phlorotannins purified extracts isolated from ten brown algal species } \\
\text { (Cystoseira tamariscifolia, C. nodicaulis, C. usneoides, Sargassum vulgare, F. spiralis, } \\
\text { Halopteris filicina, Stypocaulon scoparium, Cladostephus spongiosus, P. pavonica and } \\
\text { Saccorhiza polyschides) from Portugal }\end{array}$ & In vitro broth microdilution assay & $\begin{array}{l}\text { Less effective against fungi than bacteria } \\
\text { Phlorotannin extracts were more effective against Gram-positive than } \\
\text { Gram-negative bacteria } \\
\text { Cystoseira species and F. spiralis were the most active against Staphylococcus } \\
\text { and M. luteus (minimum MIC of } 2.0 \mathrm{mg} / \mathrm{mL} \text { ) } \\
\text { F. spiralis and C. nodicaulis extracts were the most effective against the studied } \\
\text { fungi (MIC }=3.9 \mathrm{mg} / \mathrm{mL} \text { ) }\end{array}$ & {$[131]$} \\
\hline Aqueous methanolic extracts isolated from Irish brown seaweed H. elongata & In vitro broth microdilution assay & $\begin{array}{c}\text { High antimicrobial activity against the Gram-positive bacteria, } \\
\text { L. monocytogenes and E. faecalis } \\
\text { High antimicrobial activity against the Gram-negative bacteria, P. aeruginosa } \\
\text { and S. abony }\end{array}$ & {$[276]$} \\
\hline $\begin{array}{l}\text { Extracts isolated from Eelgrass Zostera marina, whose leaf surface contained } \\
\text { hydroxycinnamic acids, flavones and flavanols }\end{array}$ & In vitro bioassays against microbial foulers & Involvement of surface-associated phenolic compounds to control yeasts & [5] \\
\hline $\begin{array}{l}\text { Free phenolic acid extracts from Nannochloropsis sp. and Spirulina sp., as well } \\
\text { as pure compounds }\end{array}$ & In vitro antifungal activity of phenols & $\begin{array}{l}\text { Antifungal activity of phenolic acid extracts of the microalgae } \\
\text { Higher activity of the natural free phenolic acid extracts ( } \mathrm{EC}_{50} \text { values of } \\
49.6 \mathrm{\mu g} / \mathrm{mL} \text { and } 33.9 \mu \mathrm{g} / \mathrm{mL} \text { for Nannochloropsis sp. and Spirulina sp., } \\
\text { respectively) than the synthetic mixtures }\end{array}$ & [27] \\
\hline $\begin{array}{l}\text { Ethanolic extracts isolated from nine marine microalgae } \\
\text { (Nannochloropsis gaditana, Dunaliella salina, Dunaliella sp., } \\
\text { Phaedactylum tricornutum, Isochrysis sp., Navicula sp., Chaeotoceros sp., } \\
\text { Chlorella sp. and Tetraselmis sp.) }\end{array}$ & In vitro broth microdilution assay & $\begin{array}{c}\text { Variable inhibitory activity against Escherichia coli, Pseudomonas aeruginosa and } \\
\text { Staphylococcus aureus (Tetraselmis sp. was the most active of all those tested } \\
\text { with MIC of } 2.6 \text { to } 3.0 \mathrm{mg} / \mathrm{mL} \text { of extract) } \\
\text { Inhibition of the growth of Candida albicans (N. gaditana showed the highest } \\
\text { activity with a MIC of } 4.0 \mathrm{mg} / \mathrm{mL} \text { of extract) } \\
\text { Aspergillus niger (fungus) was resistant to the effects of the extracts } \\
\text { Activity of the extracts was due to the presence of fatty acids, carotenoids } \\
\text { and phenols }\end{array}$ & [50] \\
\hline $\begin{array}{l}\text { Methanol, ethanol and hexane extracts from four marine microalgae } \\
\text { (Chaetoceros calcitrans, Skeletonema costatum, Chroococcus turgidus and } \\
\text { Nannochloropsis oceanica) }\end{array}$ & In vitro disc diffusion method & $\begin{array}{c}\text { Inhibitory activity against Staphylococcus aureus, Streptococcus pyogenes and } \\
\text { Bacillus subtilis } \\
\text { Antifungal activity only in Skeletonema costatum and Chroococcus turgidus }\end{array}$ & [59] \\
\hline Diphlorethohydroxycarmalol isolated from Ishige okamurae & In vitro antiviral enzyme assay & $\begin{array}{l}\text { Inhibited the activity of HIV-1 reverse transcriptase and integrase with } \mathrm{IC}_{50} \\
\text { values of } 9.1 \mu \mathrm{M} \text { and } 25.2 \mu \mathrm{M} \text {, respectively }\end{array}$ & {$[278]$} \\
\hline 8,4'-Dieckol isolated from E. cava & $\begin{array}{l}\text { In vitro: H9, H9/HIV-1IIIB, CEM-SS, C8166 cells } \\
\text { (1-50 } \mu \mathrm{M} \text { of phenol })\end{array}$ & $\begin{array}{l}\text { Inhibited the activity of HIV-1 reverse transcriptase (RT) enzyme } \\
\text { ( } 91 \% \text { inhibition ratio at } 50 \mu \mathrm{M}) \text { and HIV-1 entry } \\
\text { Exhibited the inhibitory effects against HIV-1 induced syncytia formation, } \\
\text { lytic effects and viral p24 antigen production }\end{array}$ & {$[280]$} \\
\hline 6,6'-Bieckol isolated from E. cava & $\begin{array}{c}\text { In vitro: } \begin{array}{c}\mathrm{H} 9, \mathrm{H} 9 / \mathrm{HIV}-1 \mathrm{1IIB}, \mathrm{CEM}-\mathrm{SS}, \mathrm{C} 8166 \text { cells } \\
(0.1-30 \mu \mathrm{M} \text { of phenol })\end{array}\end{array}$ & 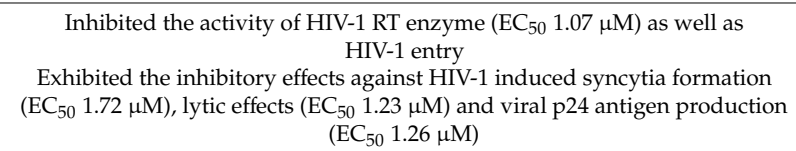 & {$[279]$} \\
\hline
\end{tabular}

MIC: minimum inhibitory concentration; HIV-1: human immunodeficiency virus-1; RT: reverse transcriptase; AIDS: acquired immunedeficiency syndrome. 


\section{Conclusions}

Marine organisms represent a widely available and renewable source of bioactives, many of them found exclusively in this environment. Phenolics are among the most active families, but contrarily to those found in terrestrial sources, marine phenolics are much less studied. Advances in the analysis of their complex and diverse structure are desirable. These tools allow their characterization, needed both for commercialization and for the study of the structure activity relationships. Classical reverse phase (RP) chromatography is the most used approach but slightly ineffective since the hydrophobic stationary phase of RP columns weakly retain these compounds that, in addition to the close polar nature among the extensively isomerized phlorotannins, make their right resolution difficult. Thus, $\mathrm{MS}^{\mathrm{n}}$ coupled to chromatographic techniques is widely used based on their mass-to-charge ratio $(\mathrm{m} / \mathrm{z})$ and fragmentation patterns ( $\mathrm{m} / \mathrm{z}$ of precursor and product ions, respectively). Quadrupole time-of-flight (qTOF) and triple quadrupole $(\mathrm{QqQ})$ analyzers have been widely used to this aim. Given the high complexity of marine phenolics, $\mathrm{MS}^{\mathrm{n}}$ spectrums help only partially to identify the polymerization degree and structure of phlorotannins. Coupling NMR and tandem mass spectrometry $\left(\mathrm{MS}^{\mathrm{n}}\right)$ with liquid chromatography is another strategy used to identify and characterize the chemical structure of this group of compounds. No less important are the advances in clean and efficient extraction methods, as well as the fractionation and purification strategies, which can promote the rational utilization of these compounds as bioactive components in functional foods, nutraceuticals and medicines. This is especially relevant since other compounds (carbohydrates, pigments, or toxic heavy metals) can be co-extracted with marine phenolics. Among the isolation techniques assayed, classical solid-liquid extraction using organic solvents is the most studied method. Alternatively, pressurized hot liquid extraction (PHLE) is a more recent option to obtain pure phlorotannins and bromophenols extracts, with lower environmental impact than solid-liquid extraction, but difficult to scale up to industrial production.

Although deficiencies in polyphenol intake do not result in specific diseases, adequate consumption of polyphenols could confer health benefits, especially related to the prevention of non-communicable diseases. The reviewed studies have revealed the multi-targeted protective effect of marine phenolics against the most prevalent diseases, such as T2DM, obesity, metabolic syndrome, Alzheimer's, or cancer, along with infectious diseases, among others. The modulatory activity of human gut microbiota has been also described, although few studies are currently available, and it would be desirable to expand them to address this aspect in depth.

Many studies have demonstrated the involvement of polyphenols in various multifactorial mechanisms underlying several diseases, due to their enzyme inhibitory effect along with their antidiabetic, antiobesity, antihypertensive, anti-inflammatory, anticancer, antimicrobial, or antiviral activities. This is an important difference compared to the available drugs used to treat most of the diseases, i.e., the ability of marine phenolics intervening in multiple pathways involved in the pathological processes. This reinforces their consideration in the pharmaceutical and cosmeceutical industries as drug substitutes. This step must be supported by the development of human studies since current understanding on the bioactivity of marine phenolics is almost exclusively based on the data available from the in vitro assays or cellular and animal models; hence, they cannot be extrapolated without reliable human clinical data.

The majority of the reported clinical trials aimed to ascertain the effect of marine phenolics on obesity and diabetes and there is not one on cancer or Alzheimer's. Regarding the polyphenol types, phlorotannins bioactivity was much more explored than bromophenols; particularly eckols and their derivatives have shown to be promising. Therefore, it is essential to design clinical trials to confirm the current knowledge about the bioactivity of marine phenols, rule out adverse effects, and study their metabolism and bioavailability for their study is almost un-existent so far.

In conclusion, marine organisms represent an important polyphenol source with promising beneficial properties to ameliorate the prevalent non-communicable diseases such as diabetes, obesity, cancer, and neurodegenerative pathologies. 
Author Contributions: Conceptualization, R.M., J.R.P.-C. and H.D.; writing-original draft preparation, R.M., J.R.P.-C. and H.D.; writing-review and editing, R.M., J.R.P.-C. and H.D. All authors have read and agreed to the published version of the manuscript.

Funding: Financial support from the Xunta de Galicia (Centro singular de investigación de Galicia accreditation 2019-2022), the European Union (European Regional Development Fund-ERDF), (Ref. ED431G2019/06) and from FONDECYT Regular project number 1180571, is gratefully acknowledged.

Acknowledgments: We appreciate the technical support of Javiera Pérez-Manríquez on managing the references. Lisa Gingles edited the English text.

Conflicts of Interest: The authors declare no conflict of interest. The funders had no role in the writing of the manuscript, or in the decision to publish the results.

\begin{tabular}{|c|c|}
\hline A2780 & Human ovarian carcinoma cell line \\
\hline A549 & Adenocarcinomic human alveolar basal epithelial cell line \\
\hline $\mathrm{A} \beta$ & Amyloid-beta peptides \\
\hline ABTS & 2, 2'-Azino-bis (3-ethylbenzothiazoline-6-sulphonic acid) \\
\hline $\mathrm{ACC}$ & Acetyl-CoA carboxylase \\
\hline ACE & Angiotensin-I converting enzyme \\
\hline $\mathrm{AChE}$ & Acetylcholinesterase \\
\hline $\mathrm{ACh}$ & Acetylcholine \\
\hline ACSL1 & Adipose acyl-CoA synthetase 1 \\
\hline $\mathrm{AD}$ & Alzheimer's disease \\
\hline A-FABP & Adipocyte fatty acid binding protein \\
\hline AGEs & Advanced glycation end-products \\
\hline AIDS & Acquired immunedeficiency syndrome \\
\hline Akt & Protein kinase B \\
\hline AMPK & AMP-activated protein kinase \\
\hline ASE & Ascorbic acid equivalents \\
\hline ATF3 & Transcription factor 3 \\
\hline B16F10 & Murine melanoma cell line \\
\hline BACE-1 & Beta-site amyloid precursor protein cleaving enzyme 1 \\
\hline BCBM & $\beta$-Carotene bleaching \\
\hline BChE & Butyrylcholinesterases \\
\hline BDNF & Brain-derived neurotrophic factor \\
\hline BT549 & Human triple negative breast cancer cell line \\
\hline $\mathrm{C} 2 \mathrm{C} 12$ & Mouse myoblast cell line \\
\hline C8166 & Human cancer cell line \\
\hline $\mathrm{CA}$ & Chelating ability \\
\hline CAA & Antioxidant assay for cellular antioxidant activity \\
\hline CAT & Catalase \\
\hline CEM-SS & Human lymphoblastic leukemia cell line \\
\hline CLPAA & Cellular lipid peroxidation antioxidant activity assay \\
\hline COSY & Homonuclear correlation spectroscopy \\
\hline GC-MS & Gas chromatography-mass spectrometry \\
\hline Glut4 & Glucose transporter 4 \\
\hline $\mathrm{C} / \mathrm{EBP} \alpha$ & CCAAT/enhancer-binding protein alpha \\
\hline COX-2 & Cyclooxygenase-2 \\
\hline CPT1A & Carnitine palmitoyltransferase I \\
\hline CVD & Cardiovascular disease \\
\hline DNA & Deoxyribonucleic acid \\
\hline $\mathrm{DPPH}$ & 2,2-Diphenyl-1-picrylhydrazyl \\
\hline E1-6 & Human Jurkat clone cell line \\
\hline EA.hy926 & Human umbilical vein endothelial cell line \\
\hline ERK & Extracellular signal-regulated kinase \\
\hline
\end{tabular}




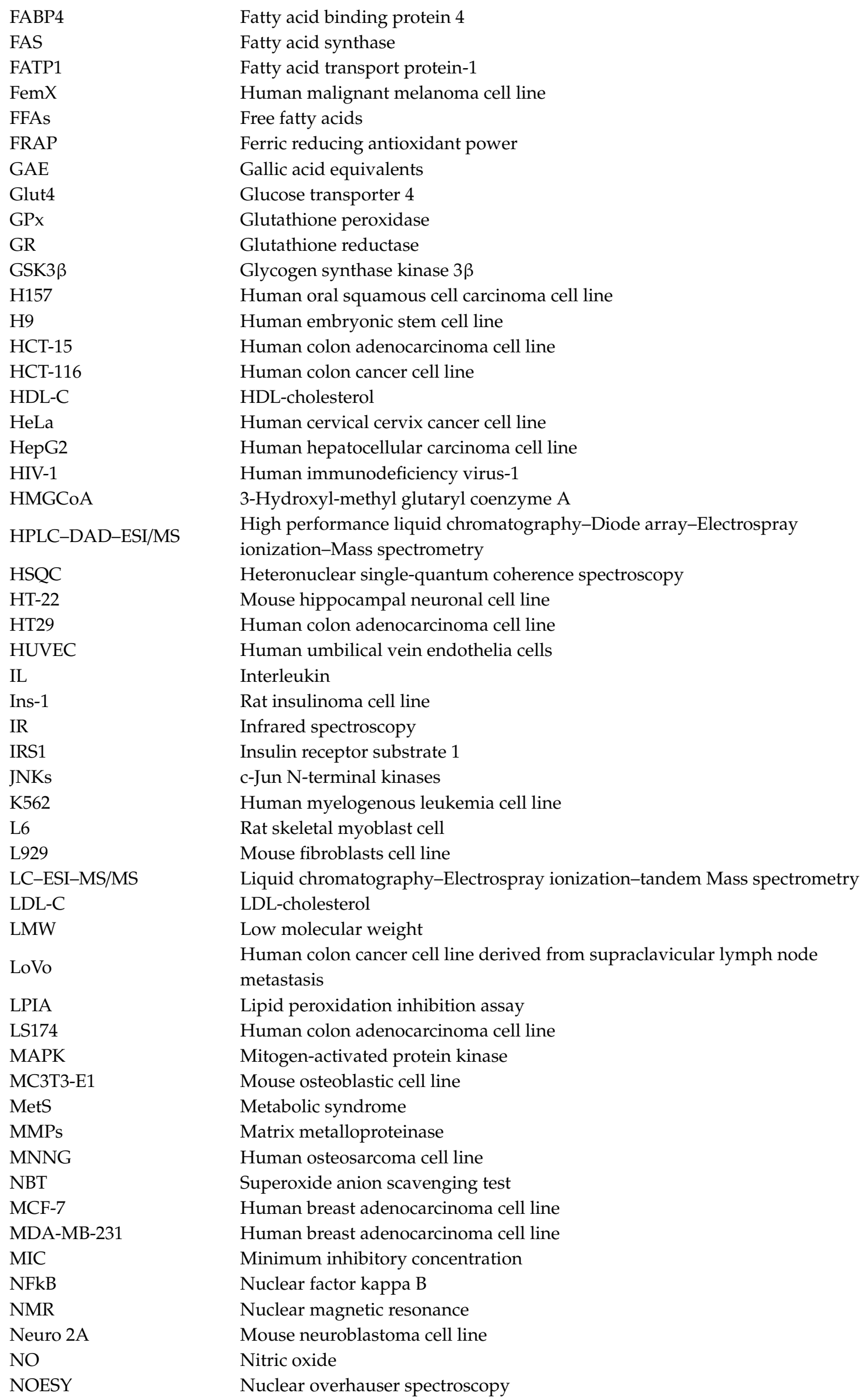




iNOS
ORAC
PANC-1
Panc89
PancTU1
PC12
PC3
PCNA
PGE2
PGU
PI3K
PPAR $\gamma$
PTP1B
RAGE
RAW 264.7
RINm5F
ROS
RP

RRLC-ESI-MS

RT

SaOS-2

SKBR3

SK-N-SH

SKOV3

SOD

SREBP1

SREBP-1C

SRSA

STZ

SW480

3T3-L1

T2DM

TAA

TBARs

TC

TEAC

TG

TLR

TNF $\alpha$

TOCSY

UCP-1

UPLC

UPLC-ESI-QTOF/MS

UPLC-MS

UPLC-MS/MS-TIC

VEGF

VERO

VSMC
Inducible nitric oxide synthase

Oxygen radical absorbance capacity

Human pancreatic carcinoma cell line

Human pancreatic carcinoma cell line

Human pancreatic carcinoma cell line

Rat neuronal cell line

Human prostate cancer cell line

Proliferating cell nuclear antigen

Prostaglandin E2

Phloroglucinol units

Phosphoinositide 3-kinase

Proliferator activated receptor gamma

Protein tyrosine phosphatase 1B

Receptor for advanced glycation end-products

Murine macrophage cell line

Rat insulinoma cell line (pancreatic $\beta$-cells)

Reactive oxygen species

Reducing power

Rapid resolution liquid chromatography coupled to mass spectrometry detection with negative ion electrospray ionization

Reverse transcriptase

Human osteosarcoma cell line

Human breast cancer cell line

Human neuroblastoma cell line

Human ovarian carcinoma cell line

Superoxide dismutase

Sterol regulatory element binding protein 1

Sterol regulatory element binding protein $-1 \mathrm{c}$

Superoxide radical scavenging assay

Streptozotocin

Human colon cancer cell line

Mouse adipocyte cell line

Type 2 diabetes mellitus

Total antioxidant capacity

Thiobarbituric acid reactive substances

Total cholesterol

Trolox equivalent antioxidant capacity

Triglycerides

Toll-like receptor

Tumor necrosis factor alpha

Total correlation spectroscopy

Uncoupling protein 1

Ultra-performance liquid chromatography

Ultra-performance liquid chromatography-Electrospray

ionization-Quadrupole-time-of-flight high definition-Mass spectrometry

Ultra-performance liquid chromatography-Mass spectrometry

Ultra-performance liquid chromatography-tandem Mass spectrometry-Total ion chromatogram

Vascular endothelial growth factor

Green monkey kidney cell line

Human vascular smooth muscle cell line 


\section{References}

1. Shannon, E.; Abu-Ghannam, N. Seaweeds as nutraceuticals for health and nutrition. Phycologia 2019, 58, 563-577. [CrossRef]

2. Dahlgren, E.; Enhus, C.; Lindqvist, D.; Eklund, B.; Asplund, L. Induced production of brominated aromatic compounds in the alga Ceramium tenuicorne. Environ. Sci. Pollut. Res. 2015, 22, 18107-18114. [CrossRef] [PubMed]

3. Maadane, A.; Merghoub, N.; Ainane, T.; El Arroussi, H.; Benhima, R.; Amzazi, S.; Bakri, Y.; Wahby, I. Antioxidant activity of some Moroccan marine microalgae: PUFA profiles, carotenoids and phenolic content. J. Biotechnol. 2015, 215, 13-19. [CrossRef] [PubMed]

4. Kirke, D.A.; Rai, D.K.; Smyth, T.J.; Stengel, D.B. An assessment of temporal variation in the low molecular weight phlorotannin profiles in four intertidal brown macroalgae. Algal Res. 2019, 41, 101550. [CrossRef]

5. Papazian, S.; Parrot, D.; Burýšková, B.; Weinberger, F.; Tasdemir, D. Surface chemical defence of the eelgrass Zostera marina against microbial foulers. Sci. Rep. 2019, 9, 1-12. [CrossRef]

6. Barbosa, M.; Lopes, G.; Ferreres, F.; Andrade, P.B.; Pereira, D.M.; Gil-Izquierdo, Á.; Valentão, P. Phlorotannin extracts from Fucales: Marine polyphenols as bioregulators engaged in inflammation-related mediators and enzymes. Algal Res. 2017, 28, 1-8. [CrossRef]

7. Lopes, G.; Barbosa, M.; Vallejo, F.; Gil-Izquierdo, Á.; Andrade, P.B.; Valentão, P.; Pereira, D.M.; Ferreres, F. Profiling phlorotannins from Fucus spp. of the Northern Portuguese coastline: Chemical approach by HPLC-DAD-ESI/MSn and UPLC-ESI-QTOF/MS. Algal Res. 2018, 29, 113-120. [CrossRef]

8. Lopes, G.; Barbosa, M.; Andrade, P.B.; Valentão, P. Phlorotannins from Fucales: Potential to control hyperglycemia and diabetes-related vascular complications. J. Appl. Phycol. 2019, 31, 3143-3152. [CrossRef]

9. Ravn, H.; Pedersen, M.F.; Borum, J.; Andary, C.; Anthoni, U.; Christophersen, C.; Nielsen, P.H. Seasonal variation and distribution of two phenolic compounds, rosmarinic acid and caffeic acid, in leaves and roots-rhizomes of eelgrass (Zostera marina L.). Ophelia 1994, 40, 51-61. [CrossRef]

10. Achamlale, S.; Rezzonico, B.; Grignon-Dubois, M. Rosmarinic acid from beach waste: Isolation and HPLC quantification in Zostera detritus from Arcachon lagoon. Food Chem. 2009, 113, 878-883. [CrossRef]

11. Achamlale, S.; Rezzonico, B.; Grignon-Dubois, M. Evaluation of Zostera detritus as a potential new source of zosteric acid. J. Appl. Phycol. 2009, 21, 347-352. [CrossRef]

12. Mishra, N.; Prasad, S.M.; Mishra, N. Influence of high light intensity and nitrate deprivation on growth and biochemical composition of the marine microalgae Isochrysis galbana. Brazilian Arch. Biol. Technol. 2019, 62, 19180398. [CrossRef]

13. Tierney, M.S.; Smyth, T.J.; Hayes, M.; Soler-Vila, A.; Croft, A.K.; Brunton, N. Influence of pressurised liquid extraction and solid-liquid extraction methods on the phenolic content and antioxidant activities of Irish macroalgae. Int. J. Food Sci. Technol. 2013, 48, 860-869. [CrossRef]

14. Hardouin, K.; Burlot, A.S.; Umami, A.; Tanniou, A.; Stiger-Pouvreau, V.; Widowati, I.; Bedoux, G.; Bourgougnon, N. Biochemical and antiviral activities of enzymatic hydrolysates from different invasive French seaweeds. J. Appl. Phycol. 2014, 26, 1029-1042. [CrossRef]

15. Casas, M.P.; Conde, E.; Domínguez, H.; Moure, A. Ecofriendly extraction of bioactive fractions from Sargassum muticum. Process Biochem. 2019, 79, 166-173. [CrossRef]

16. Kadam, S.U.; Tiwari, B.K.; Smyth, T.J.; O'Donnell, C.P. Optimization of ultrasound assisted extraction of bioactive components from brown seaweed Ascophyllum nodosum using response surface methodology. Ultrason. Sonochem. 2015, 23, 308-316. [CrossRef] [PubMed]

17. Parniakov, O.; Apicella, E.; Koubaa, M.; Barba, F.J.; Grimi, N.; Lebovka, N.; Pataro, G.; Ferrari, G.; Vorobiev, E. Ultrasound-assisted green solvent extraction of high-added value compounds from microalgae Nannochloropsis spp. Bioresour. Technol. 2015, 198, 262-267. [CrossRef]

18. Huang, J.J.H.; Xu, W.W.; Lin, S.L.; Cheung, P.C.K. Phytochemical profiles of marine phytoplanktons: An evaluation of their: In vitro antioxidant and anti-proliferative activities. Food Funct. 2016, 7, 5002-5017. [CrossRef]

19. Rajauria, G.; Foley, B.; Abu-Ghannam, N. Identification and characterization of phenolic antioxidant compounds from brown Irish seaweed Himanthalia elongata using LC-DAD-ESI-MS/MS. Innov. Food Sci. Emerg. Technol. 2016, 37, 261-268. [CrossRef] 
20. Rajauria, G. Optimization and validation of reverse phase HPLC method for qualitative and quantitative assessment of polyphenols in seaweed. J. Pharm. Biomed. Anal. 2018, 148, 230-237. [CrossRef]

21. Heffernan, N.; Brunton, N.P.; FitzGerald, R.J.; Smyth, T.J. Profiling of the molecular weight and structural isomer abundance of macroalgae-derived phlorotannins. Mar. Drugs 2015, 13, 509-528. [CrossRef]

22. Bogolitsyn, K.; Druzhinina, A.; Kaplitsin, P.; Ovchinnikov, D.; Parshina, A.; Kuznetsova, M. Relationship between radical scavenging activity and polymolecular properties of brown algae polyphenols. Chem. Pap. 2019, 73, 2377-2385. [CrossRef]

23. Laabir, M.; Grignon-Dubois, M.; Masseret, E.; Rezzonico, B.; Soteras, G.; Rouquette, M.; Rieuvilleneuve, F.; Cecchi, P. Algicidal effects of Zostera marina L. and Zostera noltii Hornem. extracts on the neuro-toxic bloom-forming dinoflagellate Alexandrium catenella. Aquat. Bot. 2013, 111, 16-25. [CrossRef]

24. Zenthoefer, M.; Geisen, U.; Hofmann-Peiker, K.; Fuhrmann, M.; Kerber, J.; Kirchhöfer, R.; Hennig, S.; Peipp, M.; Geyer, R.; Piker, L.; et al. Isolation of polyphenols with anticancer activity from the Baltic Sea brown seaweed Fucus vesiculosus using bioassay-guided fractionation. J. Appl. Phycol. 2017, 29, 2021-2037. [CrossRef]

25. Tierney, M.S.; Soler-Vila, A.; Rai, D.K.; Croft, A.K.; Brunton, N.P.; Smyth, T.J. UPLC-MS profiling of low molecular weight phlorotannin polymers in Ascophyllum nodosum, Pelvetia canaliculata and Fucus spiralis. Metabolomics 2014, 10, 524-535. [CrossRef]

26. Zhong, B.; Robinson, N.A.; Warner, R.D.; Barrow, C.J.; Dunshea, F.R.; Suleria, H.A.R. LC-ESI-QTOF-MS/MS characterization of seaweed phenolics and their antioxidant potential. Mar. Drugs 2020, 18, 331. [CrossRef]

27. Scaglioni, P.T.; Pagnussatt, F.A.; Lemos, A.C.; Nicolli, C.P.; Del Ponte, E.M.; Badiale-Furlong, E. Nannochloropsis sp. and Spirulina sp. as a source of antifungal compounds to mitigate contamination by Fusarium graminearum sspecies complex. Curr. Microbiol. 2019, 76, 930-938. [CrossRef]

28. Klejdus, B.; Plaza, M.; Šnóblová, M.; Lojková, L. Development of new efficient method for isolation of phenolics from sea algae prior to their rapid resolution liquid chromatographic-tandem mass spectrometric determination. J. Pharm. Biomed. Anal. 2017, 135, 87-96. [CrossRef]

29. Pilavtepe, M.; Yucel, M.; Helvaci, S.S.; Demircioglu, M.; Yesil-Celiktas, O. Optimization and mathematical modeling of mass transfer between Zostera marina residues and supercritical $\mathrm{CO}_{2}$ modified with ethanol. J. Supercrit. Fluids 2012, 68, 87-93. [CrossRef]

30. Baldrick, F.R.; McFadden, K.; Ibars, M.; Sung, C.; Moffatt, T.; Megarry, K.; Thomas, K.; Mitchell, P.; Wallace, J.M.W.; Pourshahidi, L.K.; et al. Impact of a (poly)phenol-rich extract from the brown algae Ascophyllum nodosum on DNA damage and antioxidant activity in an overweight or obese population: A randomized controlled trial. Am. J. Clin. Nutr. 2018, 108, 688-700. [CrossRef]

31. Akköz, C.; Arslan, D.; Ünver, A.; Özcan, M.M.; Yilmaz, B. Chemical composition, total phenolic and mineral contents of Enteromorpha intestinalis (1.) kütz. and cladophora glomerata (1.) kütz. seaweeds. J. Food Biochem. 2011, 35, 513-523. [CrossRef]

32. Wijesekara, I.; Kim, S.K.; Li, Y.; Li, Y.X. Phlorotannins as bioactive agents from brown algae. Process Biochem. 2011, 46, 2219-2224. [CrossRef]

33. Zidorn, C. Secondary metabolites of seagrasses (Alismatales and Potamogetonales; Alismatidae): Chemical diversity, bioactivity, and ecological function. Phytochemistry 2016, 124, 5-28. [CrossRef] [PubMed]

34. Catarino, M.D.; Silva, A.M.S.; Cardoso, S.M. Fucaceae: A source of bioactive phlorotannins. Int. J. Mol. Sci. 2017, 18, 1327. [CrossRef]

35. Montero, L.; del Pilar Sánchez-Camargo, A.; Ibáñez, E.; Gilbert-López, B. Phenolic compounds from edible algae: Bioactivity and health benefits. Curr. Med. Chem. 2018, 25, 4808-4826. [CrossRef]

36. Erpel, F.; Mateos, R.; Pérez-jiménez, J.; Pérez-correa, J.R. Phlorotannins: From isolation and structural characterization, to the evaluation of their antidiabetic and anticancer potential. Food Res. Int. 2020, 137, 109589. [CrossRef]

37. Bidleman, T.F.; Andersson, A.; Brugel, S.; Ericson, L.; Haglund, P.; Kupryianchyk, D.; Lau, D.C.P.; Liljelind, P.; Lundin, L.; Tysklind, A.; et al. Bromoanisoles and methoxylated bromodiphenyl ethers in macroalgae from Nordic coastal regions. Environ. Sci. Process. Impacts 2019, 21, 881-892. [CrossRef]

38. Cade, S.E.; Kuo, L.J.; Schultz, I.R. Polybrominated diphenyl ethers and their hydroxylated and methoxylated derivatives in seafood obtained from Puget Sound, WA. Sci. Total Environ. 2018, 630, 1149-1154. [CrossRef] 
39. Malmvärn, A.; Marsh, G.; Kautsky, L.; Athanasiadou, M.; Bergman, Å.; Asplund, L. Hydroxylated and methoxylated brominated diphenyl ethers in the red algae Ceramium tenuicorne and blue mussels from the Baltic Sea. Environ. Sci. Technol. 2005, 39, 2990-2997. [CrossRef]

40. Koch, C.; Sures, B. Environmental concentrations and toxicology of 2,4,6-tribromophenol (TBP). Environ. Pollut. 2018, 233, 706-713. [CrossRef]

41. Ragupathi Raja Kannan, R.; Arumugam, R.; Iyapparaj, P.; Thangaradjou, T.; Anantharaman, P. In vitro antibacterial, cytotoxicity and haemolytic activities and phytochemical analysis of seagrasses from the Gulf of Mannar, South India. Food Chem. 2013, 136, 1484-1489. [CrossRef]

42. Zangrando, R.; Corami, F.; Barbaro, E.; Grosso, A.; Barbante, C.; Turetta, C.; Capodaglio, G.; Gambaro, A. Free phenolic compounds in waters of the Ross Sea. Sci. Total Environ. 2019, 650, 2117-2128. [CrossRef]

43. Glombitza, K.W.; Gerstberger, G. Phlorotannins with dibenzodioxin structural elements from the brown alga Eisenia arborea. Phytochemistry 1985, 24, 543-551. [CrossRef]

44. Pal Singh, I.; Bharate, S.B. Phloroglucinol compounds of natural origin. Nat. Prod. Rep. 2006, 23, 558-591. [CrossRef]

45. Koivikko, R.; Loponen, J.; Pihlaja, K.; Jormalainen, V. High-performance liquid chromatographic analysis of phlorotannins from the brown alga Fucus vesiculosus. Phytochem. Anal. 2007, 18, 326-332. [CrossRef] [PubMed]

46. Santana-Casiano, J.M.; González-Dávila, M.; González, A.G.; Millero, F.J. Fe(III) reduction in the presence of Catechol in seawater. Aquat. Geochemistry 2010, 16, 467-482. [CrossRef]

47. Sansone, C.; Brunet, C. Promises and challenges of microalgal antioxidant production. Antioxidants 2019, 8, 199. [CrossRef] [PubMed]

48. Tibbetts, S.M.; Milley, J.E.; Lall, S.P. Chemical composition and nutritional properties of freshwater and marine microalgal biomass cultured in photobioreactors. J. Appl. Phycol. 2015, 27, 1109-1119. [CrossRef]

49. Safafar, H.; van Wagenen, J.; Møller, P.; Jacobsen, C. Carotenoids, phenolic compounds and tocopherols contribute to the antioxidative properties of some microalgae species grown on industrial wastewater. Mar. Drugs 2015, 13, 7339-7356. [CrossRef] [PubMed]

50. Maadane, A.; Merghoub, N.; El Mernissi, N.; Ainane, T.; Amzazi, S.; Wahby, I.; Bakri, Y. Antimicrobial activity of marine microalgae isolated from Moroccan coastlines. J. Microbiol. Biotechnol. Food Sci. 2017, 6, 1257-1260. [CrossRef]

51. Bhuvana, P.; Sangeetha, P.; Anuradha, V.; Ali, M.S. Spectral characterization of bioactive compounds from microalgae: N. oculata and C. vulgaris. Biocatal. Agric. Biotechnol. 2019, 19, 101094. [CrossRef]

52. Gomez, A.L.; Lopez, J.A.; Rodriguez, A.; Fortiz, J.; Martinez, L.R.; Apolinar, A.; Enriquez, L.F. Produccion de compuestos fenolicos por cuatro especies de microalgas marinas sometidas a diferentes condiciones de iluminacion. Lat. Am. J. Aquat. Res. 2016, 44, 137-143. [CrossRef]

53. Fazelian, N.; Movafeghi, A.; Yousefzadi, M.; Rahimzadeh, M. Cytotoxic impacts of CuO nanoparticles on the marine microalga Nannochloropsis oculata. Environ. Sci. Pollut. Res. 2019, 26, 17499-17511. [CrossRef] [PubMed]

54. Rico, M.; López, A.; Santana-Casiano, J.M.; González, A.G.; González-Dávila, M. Variability of the phenolic profile in the diatom Phaeodactylum tricornutum growing under copper and iron stress. Limnol. Oceanogr. 2013, 58, 144-152. [CrossRef]

55. Santana-Casiano, J.M.; González-Dávila, M.; González, A.G.; Rico, M.; López, A.; Martel, A. Characterization of phenolic exudates from Phaeodactylum tricornutum and their effects on the chemistry of $\mathrm{Fe}(\mathrm{II})-\mathrm{Fe}(\mathrm{III})$. Mar. Chem. 2014, 158, 10-16. [CrossRef]

56. Custódio, L.; Soares, F.; Pereira, H.; Barreira, L.; Vizetto-Duarte, C.; Rodrigues, M.J.; Rauter, A.P.; Alberício, F.; Varela, J. Fatty acid composition and biological activities of Isochrysis galbana T-ISO, Tetraselmis sp. and Scenedesmus sp.: Possible application in the pharmaceutical and functional food industries. J. Appl. Phycol. 2014, 26, 151-161. [CrossRef]

57. Mekdade, L.; Bey, M.; Hamed, B.; El-kebir, F.Z.; Mohamed, S.; Ayad, E.A.; June, M.; June, M. Evaluation of Antioxidant and Antiproliferative Activities of Nannochloropsis. Res. Journal Pharm., Biol. Chem. Sci. 2016, 7 , 904-913.

58. Hemalatha, A.; Parthiban, C.; Saranya, C.; Girija, K.; Anantharaman, P. Evaluation of antioxidant activities and total phenolic contents of different solvent extracts of selected marine diatoms. Indian J. Geo-Marine Sci. 2015, 44, 1630-1636. 
59. Sushanth, V.R.; Rajashekhar, M. Antioxidant and antimicrobial activities in the four species of marine microalgae isolated from Arabian Sea of Karnataka Coast. Indian J. Geo-Marine Sci. 2015, 44, 69-75.

60. Niwano, Y.; Sato, E.; Kohno, M.; Matsuyama, Y.; Kim, D.; Oda, T. Antioxidant properties of aqueous extracts from red tide plankton cultures. Biosci. Biotechnol. Biochem. 2007, 71, 1145-1153. [CrossRef]

61. Custódio, L.; Justo, T.; Silvestre, L.; Barradas, A.; Duarte, C.V.; Pereira, H.; Barreira, L.; Rauter, A.P.; Alberício, F.; Varela, J. Microalgae of different phyla display antioxidant, metal chelating and acetylcholinesterase inhibitory activities. Food Chem. 2012, 131, 134-140. [CrossRef]

62. Pang, X.; Lin, X.; Wang, P.; Zhou, X.; Yang, B.; Wang, J.; Liu, Y. Perylenequione derivatives with anticancer activities isolated from the marine sponge-derived fungus, Alternaria sp. SCSIO41014. Mar. Drugs 2018, 16, 280. [CrossRef]

63. Zhao, Z.; Ding, W.; Wang, P.-M.; Zheng, D.; Xu, J. Five polyketides isolated from the marine-derived fungus Arthrinium sp. Nat. Prod. Res. 2019, 1-6. [CrossRef] [PubMed]

64. Liu, F.; Tian, L.; Chen, G.; Zhang, L.; Liu, B.; Zhang, W.; Bai, J.; Hua, H.; Wang, H.; Pei, Y.-H. Two new compounds from a marine-derived Penicillium griseofulvum T21-03. J. Asian Nat. Prod. Res. 2017, 19, 678-683. [CrossRef] [PubMed]

65. Sun, L.L.; Shao, C.L.; Chen, J.F.; Guo, Z.Y.; Fu, X.M.; Chen, M.; Chen, Y.Y.; Li, R.; De Voogd, N.J.; She, Z.G.; et al. New bisabolane sesquiterpenoids from a marine-derived fungus Aspergillus sp. isolated from the sponge Xestospongia testudinaria. Bioorganic Med. Chem. Lett. 2012, 22, 1326-1329. [CrossRef]

66. Liu, S.; Dai, H.; Konuklugil, B.; Orfali, R.S.; Lin, W.; Kalscheuer, R.; Liu, Z.; Proksch, P. Phenolic bisabolanes from the sponge-derived fungus Aspergillus sp. Phytochem. Lett. 2016, 18, 187-191. [CrossRef]

67. Wu, Z.; Wang, Y.; Liu, D.; Proksch, P.; Yu, S.; Lin, W. Antioxidative phenolic compounds from a marine-derived fungus Aspergillus versicolor. Tetrahedron 2016, 72, 50-57. [CrossRef]

68. Hulikere, M.M.; Joshi, C.G.; Ananda, D.; Poyya, J.; Nivya, T. Antiangiogenic, wound healing and antioxidant activity of Cladosporium cladosporioides (Endophytic Fungus) isolated from seaweed (Sargassum wightii). Mycology 2016, 7, 203-211. [CrossRef]

69. El-Hawary, S.S.; Sayed, A.M.; Mohammed, R.; Hassan, H.M.; Zaki, M.A.; Rateb, M.E.; Mohammed, T.A.; Amin, E.; Abdelmohsen, U.R. Epigenetic modifiers induce bioactive phenolic metabolites in the marine-derived fungus Penicillium brevicompactum. Mar. Drugs 2018, 16, 253. [CrossRef]

70. Zheng, Y.; Chen, X.; Chen, L.; Shen, L.; Fu, X.; Chen, Q.; Chen, M.; Wang, C. Isolation and neuroprotective activity of phenolic derivatives from the marine derived fungus Penicillium janthinellum. J. Ocean Univ. China 2020, 19, 700-706. [CrossRef]

71. Lu, Z.; Zhu, H.; Fu, P.; Wang, Y.; Zhang, Z.; Lin, H.; Liu, P.; Zhuang, Y.; Hong, K.; Zhu, W. Cytotoxic polyphenols from the marine-derived fungus Penicillium expansum. J. Nat. Prod. 2010, 73, 911-914. [CrossRef] [PubMed]

72. Elnaggar, M.S.; Ebada, S.S.; Ashour, M.L.; Ebrahim, W.; Müller, W.E.G.; Mándi, A.; Kurtán, T.; Singab, A.; Lin, W.; Liu, Z.; et al. Xanthones and sesquiterpene derivatives from a marine-derived fungus Scopulariopsis sp. Tetrahedron 2016, 72, 2411-2419. [CrossRef]

73. Wang, J.F.; Qin, X.; Xu, F.Q.; Zhang, T.; Liao, S.; Lin, X.; Yang, B.; Liu, J.; Wang, L.; Tu, Z.; et al. Tetramic acid derivatives and polyphenols from sponge-derived fungus and their biological evaluation. Nat. Prod. Res. 2015, 29, 1761-1765. [CrossRef] [PubMed]

74. Blagojević, D.; Babić, O.; Rašeta, M.; Šibul, F.; Janjušević, L.; Simeunović, J. Antioxidant activity and phenolic profile in filamentous cyanobacteria: The impact of nitrogen. J. Appl. Phycol. 2018, 30, 2337-2346. [CrossRef]

75. Ijaz, S.; Hasnain, S. Antioxidant potential of indigenous cyanobacterial strains in relation with their phenolic and flavonoid contents. Nat. Prod. Res. 2016, 30, 1297-1300. [CrossRef] [PubMed]

76. Jerez-Martel, I.; García-Poza, S.; Rodríguez-Martel, G.; Rico, M.; Afonso-Olivares, C.; Gómez-Pinchetti, J.L. Phenolic profile and antioxidant activity of crude extracts from microalgae and cyanobacteria strains. J. Food Qual. 2017, 2017. [CrossRef]

77. Milović, S.; Stanković, I.; Nikolić, D.; Radović, J.; Kolundžić, M.; Nikolić, V.; Stanojković, T.; Petović, S.; Kundaković-Vasović, T. Chemical analysis of selected seaweeds and seagrass from the Adriatic Coast of Montenegro. Chem. Biodivers. 2019, 16. [CrossRef] [PubMed]

78. Steele, L.T.; Valentine, J.F. Idiosyncratic responses of seagrass phenolic production following sea urchin grazing. Mar. Ecol. Prog. Ser. 2012, 466, 81-92. [CrossRef] 
79. Mabrouk, S.B.; Reis, M.; Sousa, M.L.; Ribeiro, T.; Almeida, J.R.; Pereira, S.; Antunes, J.; Rosa, F.; Vasconcelos, V.; Achour, L.; et al. The marine seagrass Halophila stipulacea as a source of bioactive metabolites against obesity and biofouling. Mar. Drugs 2020, 18, 88. [CrossRef]

80. Cornara, L.; Pastorino, G.; Borghesi, B.; Salis, A.; Clericuzio, M.; Marchetti, C.; Damonte, G.; Burlando, B. Posidonia oceanica (L.) delile ethanolic extract modulates cell activities with skin health applications. Mar. Drugs 2018, 16, 21. [CrossRef]

81. Enerstvedt Hasle, K.; Lundberg, A.; Jordheim, M. Characterization of polyphenolic content in the aquatic plants Ruppia cirrhosa and Ruppia maritima -A source of nutritional natural products. Molecules 2018, 23, 16. [CrossRef] [PubMed]

82. Rengasamy, K.R.R.; Sadeer, N.B.; Zengin, G.; Mahomoodally, M.F.; Cziáky, Z.; Jekő, J.; Diuzheva, A.; Abdallah, H.H.; Kim, D.H. Biopharmaceutical potential, chemical profile and in silico study of the seagrass-Syringodium isoetifolium (Asch.) Dandy. S. Afr. J. Bot. 2019, 127, 167-175. [CrossRef]

83. Steele, L.T.; Caldwell, M.; Boettcher, A.; Arnold, T. Seagrass-pathogen interactions: "pseudo-induction" of turtlegrass phenolics near wasting disease lesions. Mar. Ecol. Prog. Ser. 2005, 303, 123-131. [CrossRef]

84. Trevathan-Tackett, S.M.; Lane, A.L.; Bishop, N.; Ross, C. Metabolites derived from the tropical seagrass Thalassia testudinum are bioactive against pathogenic Labyrinthula sp. Aquat. Bot. 2015, 122, 1-8. [CrossRef]

85. Styshova, O.N.; Popov, A.M.; Artyukov, A.A.; Klimovich, A.A. Main constituents of polyphenol complex from seagrasses of the genus Zostera, their antidiabetic properties and mechanisms of action. Exp. Ther. Med. 2017, 13, 1651-1659. [CrossRef]

86. Li, Y.; Mangoni, A.; Shulha, O.; Çiçek, S.S.; Zidorn, C. Cyclic diarylheptanoids deoxycymodienol and isotedarene A from Zostera marina (Zosteraceae). Tetrahedron Lett. 2019, 60, 150930. [CrossRef]

87. Grignon-Dubois, M.; Rezzonico, B.; Alcoverro, T. Regional scale patterns in seagrass defences: Phenolic acid content in Zostera noltii. Estuar. Coast. Shelf Sci. 2012, 114, 18-22. [CrossRef]

88. Manck, L.; Quintana, E.; Suárez, R.; Brun, F.G.; Hernández, I.; Ortega, M.J.; Zubía, E. Profiling of phenolic natural products in the seagrass Zostera noltei by UPLC-MS. Nat. Prod. Commun. 2017, 12, 687-690. [CrossRef]

89. Grignon-Dubois, M.; Rezzonico, B. Phenolic chemistry of the seagrass Zostera noltei Hornem. Part 1: First evidence of three infraspecific flavonoid chemotypes in three distinctive geographical regions. Phytochemistry 2018, 146, 91-101. [CrossRef]

90. Arnold, T.; Freundlich, G.; Weilnau, T.; Verdi, A.; Tibbetts, I.R. Impacts of groundwater discharge at Myora Springs (North Stradbroke Island, Australia) on the phenolic metabolism of eelgrass, Zostera muelleri, and grazing by the juvenile rabbitfish, Siganus fuscescens. PLoS ONE 2014, 9, e104738. [CrossRef]

91. Cichewicz, R.H.; Clifford, L.J.; Lassen, P.R.; Cao, X.; Freedman, T.B.; Nafie, L.A.; Deschamps, J.D.; Kenyon, V.A.; Flanary, J.R.; Holman, T.R.; et al. Stereochemical determination and bioactivity assessment of (S)-(+)-curcuphenol dimers isolated from the marine sponge Didiscus aceratus and synthesized through laccase biocatalysis. Bioorganic Med. Chem. 2005, 13, 5600-5612. [CrossRef] [PubMed]

92. Kaweetripob, W.; Mahidol, C.; Wongbundit, S.; Tuntiwachwuttikul, P.; Ruchirawat, S.; Prawat, H. Sesterterpenes and phenolic alkenes from the Thai sponge Hyrtios erectus. Tetrahedron 2018, 74, 316-323. [CrossRef]

93. Costa, M.; Coello, L.; Urbatzka, R.; Pérez, M.; Thorsteinsdottir, M. New aromatic bisabolane derivatives with lipid-reducing activity from the marine sponge Myrmekioderma sp. Mar. Drugs 2019, 17, 375. [CrossRef] [PubMed]

94. Wongbundit, S.; Mahidol, C.; Kaweetripob, W.; Prachyawarakorn, V.; Eurtivong, C.; Sahakitpichan, P.; Tuntiwachwuttikul, P.; Ruchirawat, S.; Prawat, H. Biscurcudiols, myrmekioperoxides, and myrmekiodermaral from the Thai marine sponge Myrmekioderma sp. Tetrahedron 2020, 76, 131162. [CrossRef]

95. Olsen, E.K.; Hansen, E.; Isaksson, J.; Andersen, J.H. Cellular antioxidant effect of four bromophenols from the red algae, Vertebrata lanosa. Mar. Drugs 2013, 11, 2769-2784. [CrossRef]

96. Ferreres, F.; Lopes, G.; Gil-Izquierdo, A.; Andrade, P.B.; Sousa, C.; Mouga, T.; Valentão, P. Phlorotannin extracts from fucales characterized by HPLC-DAD-ESI-MS n: Approaches to hyaluronidase inhibitory capacity and antioxidant properties. Mar. Drugs 2012, 10, 2766-2781. [CrossRef]

97. Prieto, P.; Pineda, M.; Aguilar, M. Spectrophotometric quantitation of antioxidant capacity through the formation of a phosphomolybdenum complex: Specific application to the determination of vitamin E. Anal. Biochem. 1999, 269, 337-341. [CrossRef] 
98. Cabrita, M.T.; Vale, C.; Rauter, A.P. Halogenated compounds from marine algae. Mar. Drugs 2010, 8, 2301-2317. [CrossRef]

99. Topcu, G.; Aydogmus, Z.; Imre, S.; Gören, A.C.; Pezzuto, J.M.; Clement, J.A.; Kingston, D.G.I. Brominated sesquiterpenes from the red alga Laurencia obtusa. J. Nat. Prod. 2003, 66, 1505-1508. [CrossRef]

100. Machado, L.; Magnusson, M.; Paul, N.A.; Kinley, R.; de Nys, R.; Tomkins, N. Identification of bioactives from the red seaweed Asparagopsis taxiformis that promote antimethanogenic activity in vitro. J. Appl. Phycol. 2016, 28, 3117-3126. [CrossRef]

101. Whitfield, F.B.; Last, J.H.; Shaw, K.J.; Tindale, C.R. 2,6-Dibromophenol: The cause of an iodoform-like off-flavour in some Australian crustacea. J. Sci. Food Agric. 1988, 46, 29-42. [CrossRef]

102. Kim, K.C.; Hyun, Y.J.; Hewage, S.R.K.M.; Piao, M.J.; Kang, K.A.; Kang, H.K.; Koh, Y.S.; Ahn, M.J.; Hyun, J.W. 3-Bromo-4,5-dihydroxybenzaldehyde enhances the level of reduced glutathione via the Nrf2-mediated pathway in human keratinocytes. Mar. Drugs 2017, 15, 291. [CrossRef] [PubMed]

103. Yuan, Y.; Zheng, Y.; Zhou, J.; Geng, Y.; Zou, P.; Li, Y.; Zhang, C. Polyphenol-rich extracts from brown macroalgae Lessonia trabeculate attenuate hyperglycemia and modulate gut microbiota in high-rfat diet and Streptozotocin-Induced diabetic rats. J. Agric. Food Chem. 2019, 67, 12472-12480. [CrossRef] [PubMed]

104. Rodrigues, D.; Freitas, A.C.; Pereira, L.; Rocha-Santos, T.A.P.; Vasconcelos, M.W.; Roriz, M.; Rodríguez-Alcalá, L.M.; Gomes, A.M.P.; Duarte, A.C. Chemical composition of red, brown and green macroalgae from Buarcos bay in Central West Coast of Portugal. Food Chem. 2015, 183, 197-207. [CrossRef]

105. Uribe, E.; Vega-Gálvez, A.; Heredia, V.; Pastén, A.; Di Scala, K. An edible red seaweed (Pyropia orbicularis): Influence of vacuum drying on physicochemical composition, bioactive compounds, antioxidant capacity, and pigments. J. Appl. Phycol. 2018, 30, 673-683. [CrossRef]

106. Tanna, B.; Brahmbhatt, H.R.; Mishra, A. Phenolic, flavonoid, and amino acid compositions reveal that selected tropical seaweeds have the potential to be functional food ingredients. J. Food Process. Preserv. 2019, 43, 1-10. [CrossRef]

107. Ford, L.; Theodoridou, K.; Sheldrake, G.N.; Walsh, P.J. A critical review of analytical methods used for the chemical characterisation and quantification of phlorotannin compounds in brown seaweeds. Phytochem. Anal. 2019, 30, 587-599. [CrossRef]

108. Steevensz, A.J.; MacKinnon, S.L.; Hankinson, R.; Craft, C.; Connan, S.; Stengel, D.B.; Melanson, J.E. Profiling phlorotannins in brown macroalgae by liquid chromatography-high resolution mass spectrometry. Phytochem. Anal. 2012, 23, 547-553. [CrossRef]

109. Zhang, R.; Yuen, A.K.L.; Magnusson, M.; Wright, J.T.; de Nys, R.; Masters, A.F.; Maschmeyer, T. A comparative assessment of the activity and structure of phlorotannins from the brown seaweed Carpophyllum flexuosum. Algal Res. 2018, 29, 130-141. [CrossRef]

110. Sellimi, S.; Benslima, A.; Barragan-Montero, V.; Hajji, M.; Nasri, M. Polyphenolic-protein-polysaccharide ternary conjugates from Cystoseira barbata Tunisian seaweed as potential biopreservatives: Chemical, antioxidant and antimicrobial properties. Int. J. Biol. Macromol. 2017, 105, 1375-1383. [CrossRef]

111. Trifan, A.; Vasincu, A.; Luca, S.V.; Neophytou, C.; Wolfram, E.; Opitz, S.E.W.; Sava, D.; Bucur, L.; Cioroiu, B.I.; Miron, A.; et al. Unravelling the potential of seaweeds from the Black Sea coast of Romania as bioactive compounds sources. Part I: Cystoseira barbata (Stackhouse) C. Agardh. Food Chem. Toxicol. 2019, 134, 110820. [CrossRef]

112. Olate-Gallegos, C.; Barriga, A.; Vergara, C.; Fredes, C.; García, P.; Giménez, B.; Robert, P. Identification of polyphenols from Chilean brown seaweeds extracts by LC-DAD-ESI-MS/MS. J. Aquat. Food Prod. Technol. 2019, 28, 375-391. [CrossRef]

113. Kim, S.M.; Kang, S.W.; Jeon, J.S.; Jung, Y.J.; Kim, W.R.; Kim, C.Y.; Um, B.H. Determination of major phlorotannins in Eisenia bicyclis using hydrophilic interaction chromatography: Seasonal variation and extraction characteristics. Food Chem. 2013, 138, 2399-2406. [CrossRef]

114. Cho, S.; Yang, H.; Jeon, Y.J.; Lee, C.J.; Jin, Y.H.; Baek, N.I.; Kim, D.; Kang, S.M.; Yoon, M.; Yong, H.; et al. Phlorotannins of the edible brown seaweed Ecklonia cava Kjellman induce sleep via positive allosteric modulation of gamma-aminobutyric acid type A-benzodiazepine receptor: A novel neurological activity of seaweed polyphenols. Food Chem. 2012, 132, 1133-1142. [CrossRef] [PubMed]

115. Lee, J.H.; Ko, J.Y.; Oh, J.Y.; Kim, C.Y.; Lee, H.J.; Kim, J.; Jeon, Y.J. Preparative isolation and purification of phlorotannins from Ecklonia cava using centrifugal partition chromatography by one-step. Food Chem. 2014, 158, 433-437. [CrossRef] [PubMed] 
116. Nho, J.A.; Shin, Y.S.; Jeong, H.-R.; Cho, S.; Heo, H.J.; Kim, G.H.; Kim, D.-O. Neuroprotective effects of phlorotannin-rich extract from brown seaweed Ecklonia cava on neuronal PC-12 and SH-SY5Y Cells with Oxidative Stress. J. Microbiol. Biotechnol. 2020, 30, 359-367. [CrossRef] [PubMed]

117. Wei, R.; Lee, M.S.; Lee, B.; Oh, C.W.; Choi, C.G.; Kim, H.R. Isolation and identification of anti-inflammatory compounds from ethyl acetate fraction of Ecklonia stolonifera and their anti-inflammatory action. J. Appl. Phycol. 2016, 28, 3535-3545. [CrossRef]

118. Kirke, D.A.; Smyth, T.J.; Rai, D.K.; Kenny, O.; Stengel, D.B. The chemical and antioxidant stability of isolated low molecular weight phlorotannins. Food Chem. 2017, 221, 1104-1112. [CrossRef]

119. Wang, T.; Jónsdóttir, R.; Liu, H.; Gu, L.; Kristinsson, H.G.; Raghavan, S.; Ólafsdóttir, G. Antioxidant capacities of phlorotannins extracted from the brown algae Fucus vesiculosus. J. Agric. Food Chem. 2012, 60, 5874-5883. [CrossRef]

120. Catarino, M.D.; Silva, A.M.S.; Mateus, N.; Cardoso, S.M. Optimization of phlorotannins extraction from Fucus vesiculosus and evaluation of their potential to prevent metabolic disorders. Mar. Drugs 2019, 17, 162. [CrossRef]

121. Le Lann, K.; Surget, G.; Couteau, C.; Coiffard, L.; Cérantola, S.; Gaillard, F.; Larnicol, M.; Zubia, M.; Guérard, F.; Poupart, N.; et al. Sunscreen, antioxidant, and bactericide capacities of phlorotannins from the brown macroalga Halidrys siliquosa. J. Appl. Phycol. 2016, 28, 3547-3559. [CrossRef]

122. Haraguchi, K.; Kotaki, Y.; Relox, J.R.; Romero, M.L.J.; Terada, R. Monitoring of naturally produced brominated phenoxyphenols and phenoxyanisoles in aquatic plants from the Philippines. J. Agric. Food Chem. 2010, 58, 12385-12391. [CrossRef] [PubMed]

123. Vissers, A.M.; Caligiani, A.; Sforza, S.; Vincken, J.P.; Gruppen, H. Phlorotannin Composition of Laminaria digitata. Phytochem. Anal. 2017, 28, 487-495. [CrossRef] [PubMed]

124. Xu, K.; Guo, S.; Jia, X.; Li, X.; Shi, D. Phytochemical and chemotaxonomic study on Leathesia nana (Chordariaceae). Biochem. Syst. Ecol. 2018, 81, 42-44. [CrossRef]

125. Nair, D.; Vanuopadath, M.; Balasubramanian, A.; Iyer, A.; Ganesh, S.; Anil, A.N.; Vikraman, V.; Pillai, P.; Bose, C.; Nair, B.G.; et al. Phlorotannins from Padina tetrastromatica: Structural characterisation and functional studies. J. Appl. Phycol. 2019, 31, 3131-3141. [CrossRef]

126. Li, Y.; Fu, X.; Duan, D.; Liu, X.; Xu, J.; Gao, X. Extraction and identification of phlorotannins from the brown aqlga, Sargassum fusiforme (Harvey) Setchell. Mar. Drugs 2017, 15, 49. [CrossRef]

127. Montero, L.; Sánchez-Camargo, A.P.; García-Cañas, V.; Tanniou, A.; Stiger-Pouvreau, V.; Russo, M.; Rastrelli, L.; Cifuentes, A.; Herrero, M.; Ibáñez, E. Anti-proliferative activity and chemical characterization by comprehensive two-dimensional liquid chromatography coupled to mass spectrometry of phlorotannins from the brown macroalga Sargassum muticum collected on North-Atlantic coasts. J. Chromatogr. A 2016, 1428, 115-125. [CrossRef]

128. Vázquez-Rodríguez, B.; Gutiérrez-Uribe, J.A.; Antunes-Ricardo, M.; Santos-Zea, L.; Cruz-Suárez, L.E. Ultrasound-assisted extraction of phlorotannins and polysaccharides from Silvetia compressa (Phaeophyceae). J. Appl. Phycol. 2020, 32, 1441-1453. [CrossRef]

129. Murugan, K.; Iyer, V.V. Differential growth inhibition of cancer cell lines and antioxidant activity of extracts of red, brown, and green marine algae. Vitr. Cell. Dev. Biol. - Anim. 2013, 49, 324-334. [CrossRef]

130. Aravindan, S.; Delma, C.R.; Thirugnanasambandan, S.S.; Herman, T.S.; Aravindan, N. Anti-pancreatic cancer deliverables from sea: First-hand evidence on the efficacy, molecular targets and mode of action for multifarious polyphenols from five different brown-algae. PLoS ONE 2013, 8, e61977. [CrossRef]

131. Lopes, G.; Sousa, C.; Silva, L.R.; Pinto, E.; Andrade, P.B.; Bernardo, J.; Mouga, T.; Valentão, P. Can phlorotannins purified extracts constitute a novel pharmacological alternative for microbial infections with associated inflammatory conditions? PLoS ONE 2012, 7, e31145. [CrossRef] [PubMed]

132. Audibert, L.; Fauchon, M.; Blanc, N.; Hauchard, D.; Ar Gall, E. Phenolic compounds in the brown seaweed Ascophyllum nodosum: Distribution and radical-scavenging activities. Phytochem. Anal. 2010, 21, 399-405. [CrossRef] [PubMed]

133. Kurth, C.; Welling, M.; Pohnert, G. Sulfated phenolic acids from Dasycladales siphonous green algae. Phytochemistry 2015, 117, 417-423. [CrossRef] [PubMed]

134. De Oliveira, A.L.L.; Da Silva, D.B.; Lopes, N.P.; Debonsi, H.M.; Yokoya, N.S. Chemical constituents from red algae Bostrychia radicans (Rhodomelaceae): New amides and phenolic compounds. Quim. Nova 2012, 35, 2186-2188. [CrossRef] 
135. Dahlgren, E.; Lindqvist, D.; Dahlgren, H.; Asplund, L.; Lehtilä, K. Trophic transfer of naturally produced brominated aromatic compounds in a Baltic Sea food chain. Chemosphere 2016, 144, 1597-1604. [CrossRef] [PubMed]

136. Lindqvist, D.; Dahlgren, E.; Asplund, L. Biosynthesis of hydroxylated polybrominated diphenyl ethers and the correlation with photosynthetic pigments in the red alga Ceramium tenuicorne. Phytochemistry 2017, 133, 51-58. [CrossRef]

137. Mikami, D.; Kurihara, H.; Kim, S.M.; Takahashi, K. Red algal bromophenols as glucose 6-phosphate dehydrogenase inhibitors. Mar. Drugs 2013, 11, 4050-4057. [CrossRef]

138. Mikami, D.; Kurihara, H.; Ono, M.; Kim, S.M.; Takahashi, K. Inhibition of algal bromophenols and their related phenols against glucose 6-phosphate dehydrogenase. Fitoterapia 2016, 108, 20-25. [CrossRef]

139. Islam, M.R.; Mikami, D.; Kurihara, H. Two new algal bromophenols from Odonthalia corymbifera. Tetrahedron Lett. 2017, 58, 4119-4121. [CrossRef]

140. Lever, J.; Curtis, G.; Brkljača, R.; Urban, S. Bromophenolics from the reed alga Polysiphonia decipiens. Mar. Drugs 2019, 17, 497. [CrossRef]

141. Kim, S.Y.; Kim, S.R.; Oh, M.J.; Jung, S.J.; Kang, S.Y. In Vitro antiviral activity of red alga, Polysiphonia morrowii extract and its bromophenols against fish pathogenic infectious hematopoietic necrosis virus and infectious pancreatic necrosis virus. J. Microbiol. 2011, 49, 102-106. [CrossRef] [PubMed]

142. Choi, Y.K.; Ye, B.R.; Kim, E.A.; Kim, J.; Kim, M.S.; Lee, W.W.; Ahn, G.N.; Kang, N.; Jung, W.K.; Heo, S.J. Bis (3-bromo-4,5-dihydroxybenzyl) ether, a novel bromophenol from the marine red alga Polysiphonia morrowii that suppresses LPS-induced inflammatory response by inhibiting ROS-mediated ERK signaling pathway in RAW 264.7 macrophages. Biomed. Pharmacother. 2018, 103, 1170-1177. [CrossRef] [PubMed]

143. Li, K.; Li, X.M.; Gloer, J.B.; Wang, B.G. New nitrogen-containing bromophenols from the marine red alga Rhodomela confervoides and their radical scavenging activity. Food Chem. 2012, 135, 868-872. [CrossRef] [PubMed]

144. Liu, X.; Li, X.; Gao, L.; Cui, C.; Li, C.; Li, J.; Wang, B. Extraction and PTP1B inhibitory activity of bromophenols from the marine red alga Symphyocladia latiuscula. Chinese J. Oceanol. Limnol. 2011, 29, 686-690. [CrossRef]

145. Xu, X.; Yin, L.; Gao, L.; Gao, J.; Chen, J.; Li, J.; Song, F. Two new bromophenols with radical scavenging activity from marine red alga Symphyocladia latiuscula. Mar. Drugs 2013, 11, 842-847. [CrossRef]

146. Xu, X.; Yin, L.; Gao, J.; Gao, L.; Song, F. Antifungal bromophenols from marine red alga Symphyocladia latiuscula. Chem. Biodivers. 2014, 11, 807-811. [CrossRef]

147. Xu, X.; Yang, H.; Khalil, Z.G.; Yin, L.; Xiao, X.; Neupane, P.; Bernhardt, P.V.; Salim, A.A.; Song, F.; Capon, R.J. Chemical diversity from a Chinese marine red alga, Symphyocladia latiuscula. Mar. Drugs 2017, 15, 374. [CrossRef]

148. Xu, X.; Yang, H.; Khalil, Z.G.; Yin, L.; Xiao, X.; Salim, A.A.; Song, F.; Capon, R.J. Bromocatechol conjugates from a Chinese marine red alga, Symphyocladia latiuscula. Phytochemistry 2019, 158, 20-25. [CrossRef]

149. Paudel, P.; Seong, S.H.; Zhou, Y.; Park, H.J.; Jung, H.A.; Choi, J.S. Anti-Alzheimer's Disease Activity of Bromophenols from a Red Alga, Symphyocladia latiuscula (Harvey) Yamada. ACS Omega 2019, 4, 12259-12270. [CrossRef]

150. Hofer, S.; Hartmann, A.; Orfanoudaki, M.; Ngoc, H.N.; Nagl, M.; Karsten, U.; Heesch, S.; Ganzera, M. Development and validation of an HPLC method for the quantitative analysis of bromophenolic compounds in the red alga Vertebrata lanosa. Mar. Drugs 2019, 17, 675. [CrossRef]

151. Huang, D.; Boxin, O.U.; Prior, R.L. The chemistry behind antioxidant capacity assays. J. Agric. Food Chem. 2005, 53, 1841-1856. [CrossRef] [PubMed]

152. Tierney, M.S.; Smyth, T.J.; Rai, D.K.; Soler-Vila, A.; Croft, A.K.; Brunton, N. Enrichment of polyphenol contents and antioxidant activities of Irish brown macroalgae using food-friendly techniques based on polarity and molecular size. Food Chem. 2013, 139, 753-761. [CrossRef] [PubMed]

153. Lim, S.N.; Cheung, P.C.K.; Ooi, V.E.C.; Ang, P.O. Evaluation of antioxidative activity of extracts from a brown seaweed, Sargassum siliquastrum. J. Agric. Food Chem. 2002, 50, 3862-3866. [CrossRef] [PubMed]

154. Martins, C.D.L.; Ramlov, F.; Nocchi Carneiro, N.P.; Gestinari, L.M.; dos Santos, B.F.; Bento, L.M.; Lhullier, C.; Gouvea, L.; Bastos, E.; Horta, P.A.; et al. Antioxidant properties and total phenolic contents of some tropical seaweeds of the Brazilian coast. J. Appl. Phycol. 2013, 25, 1179-1187. [CrossRef]

155. Sevimli-Gur, C.; Yesil-Celiktas, O. Cytotoxicity screening of supercritical fluid extracted seaweeds and phenylpropanoids. Mol. Biol. Rep. 2019, 46, 3691-3699. [CrossRef] [PubMed] 
156. Fraga, C.G.; Croft, K.D.; Kennedy, D.O.; Tomás-Barberán, F.A. The effects of polyphenols and other bioactives on human health. Food Funct. 2019, 10, 514-528. [CrossRef]

157. Williams, R.; Colagiuri, S.; Chan, J.; Gregg, E.W.; Ke, C.; Lim, L.-L.; Yang, X. IDF Atlas, 9th ed.; International Diabetes Federation: Brussels, Belgium, 2019; ISBN 978-2-930229-87-4.

158. World Health Organization. Global Report on Diabetes. Available online: https://apps.who.int/iris/handle/ 10665/204871 (accessed on 7 August 2020).

159. Hermans, M.P.; Dath, N. Prevalence and co-prevalence of comorbidities in Belgian patients with type 2 diabetes mellitus: A transversal, descriptive study. Acta Clin. Belgica Int. J. Clin. Lab. Med. 2018, 73, 68-74. [CrossRef]

160. Lee, S.H.; Jeon, Y.J. Anti-diabetic effects of brown algae derived phlorotannins, marine polyphenols through diverse mechanisms. Fitoterapia 2013, 86, 129-136. [CrossRef]

161. Gunathilaka, T.L.; Samarakoon, K.; Ranasinghe, P.; Peiris, L.D.C. Antidiabetic potential of marine brown algae - A Mini Review. J. Diabetes Res. 2020, 2020. [CrossRef]

162. Murugan, A.C.; Karim, M.R.; Yusoff, M.B.M.; Tan, S.H.; Asras, M.F.B.F.; Rashid, S.S. New insights into seaweed polyphenols on glucose homeostasis. Pharm. Biol. 2015, 53, 1087-1097. [CrossRef]

163. Zhao, C.; Yang, C.; Liu, B.; Lin, L.; Sarker, S.D.; Nahar, L.; Yu, H.; Cao, H.; Xiao, J. Bioactive compounds from marine macroalgae and their hypoglycemic benefits. Trends Food Sci. Technol. 2018, 72, 1-12. [CrossRef]

164. Benalla, W.; Bellahcen, S.; Bnouham, M. Antidiabetic medicinal plants as a source of alpha glucosidase Inhibitors. Curr. Diabetes Rev. 2010, 6, 247-254. [CrossRef] [PubMed]

165. Lee, S.H.; Yong-Li; Karadeniz, F.; Kim, M.M.; Kim, S.K. $\alpha$-Glucosidase and $\alpha$-amylase inhibitory activities of phloroglucinal derivatives from edible marine brown alga, Ecklonia cava. J. Sci. Food Agric. 2009, 89, 1552-1558. [CrossRef]

166. Nwosu, F.; Morris, J.; Lund, V.A.; Stewart, D.; Ross, H.A.; McDougall, G.J. Anti-proliferative and potential anti-diabetic effects of phenolic-rich extracts from edible marine algae. Food Chem. 2011, 126, 1006-1012. [CrossRef]

167. Lordan, S.; Smyth, T.J.; Soler-Vila, A.; Stanton, C.; Paul Ross, R. The $\alpha$-amylase and $\alpha$-glucosidase inhibitory effects of Irish seaweed extracts. Food Chem. 2013, 141, 2170-2176. [CrossRef]

168. Kellogg, J.; Grace, M.H.; Lila, M.A. Phlorotannins from alaskan seaweed inhibit carbolytic enzyme activity. Mar. Drugs 2014, 12, 5277-5294. [CrossRef]

169. Sharifuddin, Y.; Chin, Y.X.; Lim, P.E.; Phang, S.M. Potential bioactive compounds from seaweed for diabetes management. Mar. Drugs 2015, 13, 5447-5491. [CrossRef]

170. Park, S.R.; Kim, J.H.; Jang, H.D.; Yang, S.Y.; Kim, Y.H. Inhibitory activity of minor phlorotannins from Ecklonia cava on $\alpha$-glucosidase. Food Chem. 2018, 257, 128-134. [CrossRef]

171. Ezzat, S.M.; El Bishbishy, M.H.; Habtemariam, S.; Salehi, B.; Sharifi-Rad, M.; Martins, N.; Sharifi-Rad, J. Looking at marine-derived bioactive molecules as upcoming anti-diabetic agents: A special emphasis on PTP1B inhibitors. Molecules 2018, 23, 3334. [CrossRef]

172. Xu, Q.; Luo, J.; Wu, N.; Zhang, R.; Shi, D. BPN, a marine-derived PTP1B inhibitor, activates insulin signaling and improves insulin resistance in C2C12 myotubes. Int. J. Biol. Macromol. 2018, 106, 379-386. [CrossRef]

173. Luo, J.; Hou, Y.; Xie, M.; Ma, W.; Shi, D.; Jiang, B. CYC31, A Natural bromophenol PTP1B inhibitor, activates insulin signaling and improves long chain-fatty acid oxidation in C2C12 Myotubes. Mar. Drugs 2020, 18, 267. [CrossRef]

174. Boyd, A.C.; Abdel-Wahab, Y.H.A.; McKillop, A.M.; McNulty, H.; Barnett, C.R.; O'Harte, F.P.M.; Flatt, P.R. Impaired ability of glycated insulin to regulate plasma glucose and stimulate glucose transport and metabolism in mouse abdominal muscle. Biochim. Biophys. Acta Gen. Subj. 2000, 1523, 128-134. [CrossRef]

175. Iannuzzi, C.; Borriello, M.; Carafa, V.; Altucci, L.; Vitiello, M.; Balestrieri, M.L.; Ricci, G.; Irace, G.; Sirangelo, I. D-ribose-glycation of insulin prevents amyloid aggregation and produces cytotoxic adducts. Biochim. Biophys. Acta Mol. Basis Dis. 2016, 1862, 93-104. [CrossRef] [PubMed]

176. Singh, V.P.; Bali, A.; Singh, N.; Jaggi, A.S. Advanced glycation end products and diabetic complications. Korean J. Physiol. Pharmacol. 2014, 18, 1-14. [CrossRef] [PubMed]

177. Sugiura, S.; Minami, Y.; Taniguchi, R.; Tanaka, R.; Miyake, H.; Mori, T.; Ueda, M.; Shibata, T. Evaluation of anti-glycation activities of phlorotannins in human and bovine serum albumin-methylglyoxal models. Nat. Prod. Commun. 2017, 12, 1793-1796. [CrossRef] 
178. Shakambari, G.; Ashokkumar, B.; Varalakshmi, P. Phlorotannins from Brown Algae: Inhibition of advanced glycation end products formation in high glucose induced Caenorhabditis elegans. Indian J. Exp. Biol. 2015, 53, 371-379.

179. Seong, S.H.; Paudel, P.; Jung, H.A.; Choi, J.S. Identifying phlorofucofuroeckol-A as a dual inhibitor of amyloid- $\beta 25-35$ self-aggregation and insulin glycation: Elucidation of the molecular mechanism of action. Mar. Drugs 2019, 17, 600. [CrossRef]

180. Malin, S.K.; Finnegan, S.; Fealy, C.E.; Filion, J.; Rocco, M.B.; Kirwan, J.P. B-Cell dysfunction is associated with metabolic syndrome severity in adults. Metab. Syndr. Relat. Disord. 2014, 12, 79-85. [CrossRef]

181. Lee, S.H.; Kang, S.M.; Ko, S.C.; Kang, M.C.; Jeon, Y.J. Octaphlorethol A, a novel phenolic compound isolated from Ishige foliacea, protects against streptozotocin-induced pancreatic $\beta$ cell damage by reducing oxidative stress and apoptosis. Food Chem. Toxicol. 2013, 59, 643-649. [CrossRef]

182. Kim, E.A.; Kang, M.C.; Lee, J.H.; Kang, N.; Lee, W.; Oh, J.Y.; Yang, H.W.; Lee, J.S.; Jeon, Y.J. Protective effect of marine brown algal polyphenols against oxidative stressed zebrafish with high glucose. RSC Adv. 2015, 5, 25738-25746. [CrossRef]

183. Cha, S.H.; Kim, H.S.; Hwang, Y.; Jeon, Y.J.; Jun, H.S. Polysiphonia japonica extract attenuates palmitate-induced toxicity and enhances insulin secretion in pancreatic beta-cells. Oxid. Med. Cell. Longev. 2018, 2018. [CrossRef] [PubMed]

184. Sheetz, M.J.; King, G.L. Molecular understanding of hyperglycemia's adverse effects for diabetic complications. J. Am. Med. Assoc. 2002, 288, 2579-2588. [CrossRef] [PubMed]

185. Lee, S.H.; Kang, S.M.; Ko, S.C.; Lee, D.H.; Jeon, Y.J. Octaphlorethol A, a novel phenolic compound isolated from a brown alga, Ishige foliacea, increases glucose transporter 4-mediated glucose uptake in skeletal muscle cells. Biochem. Biophys. Res. Commun. 2012, 420, 576-581. [CrossRef] [PubMed]

186. Cai, Y.; Wang, Q.; Ling, Z.; Pipeleers, D.; McDermott, P.; Pende, M.; Heimberg, H.; Van de Casteele, M. Akt activation protects pancreatic beta cells from AMPK-mediated death through stimulation of mTOR. Biochem. Pharmacol. 2008, 75, 1981-1993. [CrossRef] [PubMed]

187. Lee, S.H.; Park, M.H.; Heo, S.J.; Kang, S.M.; Ko, S.C.; Han, J.S.; Jeon, Y.J. Dieckol isolated from Ecklonia cava inhibits $\alpha$-glucosidase and $\alpha$-amylase in vitro and alleviates postprandial hyperglycemia in streptozotocin-induced diabetic mice. Food Chem. Toxicol. 2010, 48, 2633-2637. [CrossRef] [PubMed]

188. Lee, H.A.; Lee, J.H.; Han, J.S. A phlorotannin constituent of Ecklonia cava alleviates postprandial hyperglycemia in diabetic mice. Pharm. Biol. 2017, 55, 1149-1154. [CrossRef]

189. Murray, M.; Dordevic, A.L.; Ryan, L.; Bonham, M.P. The impact of a single dose of a polyphenol-rich seaweed extract on postprandial glycaemic control in healthy adults: A randomised cross-over trial. Nutrients 2018, 10, 270. [CrossRef]

190. Kang, M.C.; Wijesinghe, W.A.J.P.; Lee, S.H.; Kang, S.M.; Ko, S.C.; Yang, X.; Kang, N.; Jeon, B.T.; Kim, J.; Lee, D.H.; et al. Dieckol isolated from brown seaweed Ecklonia cava attenuates type II diabetes in $\mathrm{db} / \mathrm{db}$ mouse model. Food Chem. Toxicol. 2013, 53, 294-298. [CrossRef]

191. Yan, X.; Yang, C.; Lin, G.; Chen, Y.; Miao, S.; Liu, B.; Zhao, C. Antidiabetic potential of green seaweed Enteromorpha prolifera flavonoids regulating insulin signaling pathway and gut microbiota in Type 2 Diabetic Mice. J. Food Sci. 2019, 84, 165-173. [CrossRef]

192. Lee, S.H.; Jeon, Y.J. Efficacy and safety of a dieckol-rich extract (AG-dieckol) of brown algae, Ecklonia cava, in pre-diabetic individuals: A double-blind, randomized, placebo-controlled clinical trial. Food Funct. 2015, 6, 853-858. [CrossRef]

193. Cavalot, F.; Petrelli, A.; Traversa, M.; Bonomo, K.; Fiora, E.; Conti, M.; Anfossi, G.; Costa, G.; Trovati, M. Postprandial blood glucose is a stronger predictor of cardiovascular events than fasting blood glucose in type 2 diabetes mellitus, particularly in women: Lessons from the San Luigi Gonzaga diabetes study. J. Clin. Endocrinol. Metab. 2006, 91, 813-819. [CrossRef] [PubMed]

194. Abdali, D.; Samson, S.E.; Grover, A.K. How effective are antioxidant supplements in obesity and diabetes? Med. Princ. Pract. 2015, 24, 201-215. [CrossRef] [PubMed]

195. Gregor, M.F.; Hotamisligil, G.S. Inflammatory mechanisms in obesity. Annu. Rev. Immunol. 2011, 29 , 415-445. [CrossRef] [PubMed]

196. Jung, U.J.; Choi, M.S. Obesity and its metabolic complications: The role of adipokines and the relationship between obesity, inflammation, insulin resistance, dyslipidemia and nonalcoholic fatty liver disease. Int. J. Mol. Sci. 2014, 15, 6184-6223. [CrossRef] 
197. Marseglia, L.; Manti, S.; D’Angelo, G.; Nicotera, A.; Parisi, E.; Di Rosa, G.; Gitto, E.; Arrigo, T. Oxidative stress in obesity: A critical component in human diseases. Int. J. Mol. Sci. 2015, 16, 378-400. [CrossRef]

198. Eom, S.H.; Lee, M.S.; Lee, E.W.; Kim, Y.M.; Kim, T.H. Pancreatic lipase inhibitory activity of phlorotannins isolated from Eisenia bicyclis. Phyther. Res. 2013, 27, 148-151. [CrossRef]

199. Austin, C.; Stewart, D.; Allwood, J.W.; McDougall, G.J. Extracts from the edible seaweed Ascophyllum nodosum, inhibit lipase activity in vitro: Contributions of phenolic and polysaccharide components. Food Funct. 2018, 9, 502-510. [CrossRef]

200. Franssen, R.; Monajemi, H.; Stroes, E.S.G.; Kastelein, J.J.P. Obesity and dyslipidemia. Med. Clin. N. Am. 2011, 95, 893-902. [CrossRef]

201. Ko, S.C.; Lee, M.; Lee, J.H.; Lee, S.H.; Lim, Y.; Jeon, Y.J. Dieckol, a phlorotannin isolated from a brown seaweed, Ecklonia cava, inhibits adipogenesis through AMP-activated protein kinase (AMPK) activation in 3T3-L1 preadipocytes. Environ. Toxicol. Pharmacol. 2013, 36, 1253-1260. [CrossRef]

202. Jung, H.A.; Jung, H.J.; Jeong, H.Y.; Kwon, H.J.; Ali, M.Y.; Choi, J.S. Phlorotannins isolated from the edible brown alga Ecklonia stolonifera exert anti-adipogenic activity on 3T3-L1 adipocytes by downregulating $\mathrm{C} / \mathrm{EBP} \alpha$ and PPAR $\gamma$. Fitoterapia 2014, 92, 260-269. [CrossRef]

203. Kwon, T.H.; Wu, Y.X.; Kim, J.S.; Woo, J.H.; Park, K.T.; Kwon, O.J.; Seo, H.J.; Kim, T.; Park, N.H. 6,6'-Bieckol inhibits adipocyte differentiation through downregulation of adipogenesis and lipogenesis in 3T3-L1 cells. J. Sci. Food Agric. 2015, 95, 1830-1837. [CrossRef] [PubMed]

204. Kong, C.S.; Kim, H.; Seo, Y. Edible brown alga Ecklonia cava derived phlorotannin-induced anti-adipogenic activity in vitro. J. Food Biochem. 2015, 39, 1-10. [CrossRef]

205. Salas, A.; Noé, V.; Ciudad, C.J.; Romero, M.M.; Remesar, X.; Esteve, M. Short-term oleoyl-estrone treatment affects capacity to manage lipids in rat adipose tissue. BMC Genom. 2007, 8, 292. [CrossRef] [PubMed]

206. Izquierdo, A.G.; Crujeiras, A.B.; Casanueva, F.F.; Carreira, M.C. Leptin, obesity, and leptin resistance: Where are we 25 years later? Nutrients 2019, 11, 2704. [CrossRef]

207. Kim, I.H.; Nam, T.J. Enzyme-treated Ecklonia cava extract inhibits adipogenesis through the downregulation of $\mathrm{C} / \mathrm{EBP} \alpha$ in 3T3-L1 adipocytes. Int. J. Mol. Med. 2017, 39, 636-644. [CrossRef]

208. Karadeniz, F.; Ahn, B.N.; Kim, J.A.; Seo, Y.; Jang, M.S.; Nam, K.H.; Kim, M.; Lee, S.H.; Kong, C.S. Phlorotannins suppress adipogenesis in pre-adipocytes while enhancing osteoblastogenesis in pre-osteoblasts. Arch. Pharm. Res. 2015, 38, 2172-2182. [CrossRef]

209. Choi, H.S.; Jeon, H.J.; Lee, O.H.; Lee, B.Y. Dieckol, a major phlorotannin in Ecklonia cava, suppresses lipid accumulation in the adipocytes of high-fat diet-fed zebrafish and mice: Inhibition of early adipogenesis via cell-cycle arrest and AMPK $\alpha$ activation. Mol. Nutr. Food Res. 2015, 59, 1458-1471. [CrossRef]

210. Ko, S.C.; Ding, Y.; Kim, J.; Ye, B.R.; Kim, E.A.; Jung, W.K.; Heo, S.J.; Lee, S.H. Bromophenol (5-bromo-3,4-dihydroxybenzaldehyde) isolated from red alga Polysiphonia morrowii inhibits adipogenesis by regulating expression of adipogenic transcription factors and AMP-activated protein kinase activation in 3T3-L1 adipocytes. Phyther. Res. 2019, 33, 737-744. [CrossRef]

211. Kellogg, J.; Esposito, D.; Grace, M.H.; Komarnytsky, S.; Lila, M.A. Alaskan seaweeds lower inflammation in RAW 264.7 macrophages and decrease lipid accumulation in 3T3-L1 adipocytes. J. Funct. Foods 2015, 15, 396-407. [CrossRef]

212. Song, F.; Del Pozo, C.H.; Rosario, R.; Zou, Y.S.; Ananthakrishnan, R.; Xu, X.; Patel, P.R.; Benoit, V.M.; Yan, S.F.; $\mathrm{Li}, \mathrm{H}$;; et al. RAGE regulates the metabolic and inflammatory response to high-fat feeding in mice. Diabetes 2014, 63, 1948-1965. [CrossRef]

213. Choi, J.; Oh, S.; Son, M.; Byun, K. Pyrogallol-phloroglucinol-6,6-bieckol alleviates obesity and systemic inflammation in a mouse model by reducing expression of RAGE and RAGE ligands. Mar. Drugs 2019, 17, 612. [CrossRef] [PubMed]

214. Yeo, A.R.; Lee, J.; Tae, I.H.; Park, S.R.; Cho, Y.H.; Lee, B.H.; Cheol Shin, H.; Kim, S.H.; Yoo, Y.C. Anti-hyperlipidemic effect of polyphenol extract (Seapolynol ${ }^{\mathrm{TM}}$ ) and dieckol isolated from Ecklonia cava in in vivo and in vitro models. Prev. Nutr. Food Sci. 2012, 17, 1-7. [CrossRef] [PubMed]

215. Park, E.Y.; Kim, E.H.; Kim, M.H.; Seo, Y.W.; Lee, J.I.; Jun, H.S. Polyphenol-rich fraction of brown alga Ecklonia cava collected from Gijang, Korea, reduces obesity and glucose levels in high-fat diet-induced obese mice. Evidence-based Complement. Altern. Med. 2012, 2012. [CrossRef] [PubMed] 
216. Eo, H.; Jeon, Y.J.; Lee, M.; Lim, Y. Brown alga Ecklonia cava polyphenol extract ameliorates hepatic lipogenesis, oxidative stress, and inflammation by activation of AMPK and SIRT1 in high-fat diet-induced obese mice. J. Agric. Food Chem. 2015, 63, 349-359. [CrossRef]

217. Ding, Y.; Wang, L.; Im, S.; Hwang, O.; Kim, H.S.; Kang, M.C.; Lee, S.H. Anti-obesity effect of diphlorethohydroxycarmalol isolated from brown alga Ishige okamurae in high-fat diet-induced obese mice. Mar. Drugs 2019, 17, 637. [CrossRef]

218. Shin, H.C.; Kim, S.H.; Park, Y.; Lee, B.H.; Hwang, H.J. Effects of 12-week oral supplementation of Ecklonia cava polyphenols on anthropometric and blood lipid parameters in overweight Korean individuals: A double-blind randomized clinical trial. Phyther. Res. 2012, 26, 363-368. [CrossRef]

219. Samson, S.L.; Garber, A.J. Metabolic syndrome. Endocrinol. Metab. Clin. N. Am. 2014, 43, 1-23. [CrossRef]

220. Alberti, K.G.M.M.; Eckel, R.H.; Grundy, S.M.; Zimmet, P.Z.; Cleeman, J.I.; Donato, K.A.; Fruchart, J.C.; James, W.P.T.; Loria, C.M.; Smith, S.C. Harmonizing the metabolic syndrome: A joint interim statement of the international diabetes federation task force on epidemiology and prevention; National Heart, Lung, and Blood Institute; American Heart Association; World Heart Federation; International. Circulation 2009, 120, 1640-1645. [CrossRef]

221. Stefanska, A.; Bergmann, K.; Sypniewska, G. Metabolic Syndrome and Menopause. In Advances in Clinical Chemistry; Elsevier Inc.: Amsterdam, The Netherlands, 2015; Volume 72, pp. 1-75. ISBN 9780128033142.

222. Park, J.K.; Woo, H.W.; Kim, M.K.; Shin, J.; Lee, Y.H.; Shin, D.H.; Shin, M.H.; Choi, B.Y. Dietary iodine, seaweed consumption, and incidence risk of metabolic syndrome among postmenopausal women: A prospective analysis of the Korean Multi-Rural Communities Cohort Study (MRCohort). Eur. J. Nutr. 2020. [CrossRef]

223. Vijayan, R.; Chitra, L.; Penislusshiyan, S.; Palvannan, T. Exploring bioactive fraction of Sargassum wightii: In vitro elucidation of angiotensin-i-converting enzyme inhibition and antioxidant potential. Int. J. Food Prop. 2018, 21, 674-684. [CrossRef]

224. Son, M.; Oh, S.; Lee, H.S.; Ryu, B.M.; Jiang, Y.; Jang, J.T.; Jeon, Y.J.; Byun, K. Pyrogallolphloroglucinol-6,6'-bieckol from Ecklonia cava improved blood circulation in diet-induced obese and diet-induced hypertension mouse models. Mar. Drugs 2019, 17, 272. [CrossRef]

225. Kammoun, I.; Ben Salah, H.; Ben Saad, H.; Cherif, B.; Droguet, M.; Magné, C.; Kallel, C.; Boudawara, O.; Hakim, A.; Gharsallah, N.; et al. Hypolipidemic and cardioprotective effects of Ulva lactuca ethanolic extract in hypercholesterolemic mice. Arch. Physiol. Biochem. 2018, 124, 313-325. [CrossRef] [PubMed]

226. Wanyonyi, S.; Du Preez, R.; Brown, L.; Paul, N.A.; Panchal, S.K. Kappaphycus alvarezii as a food supplement prevents diet-induced metabolic syndrome in rats. Nutrients 2017, 9, 1261. [CrossRef]

227. Gómez-Guzmán, M.; Rodríguez-Nogales, A.; Algieri, F.; Gálvez, J. Potential role of seaweed polyphenols in cardiovascular-associated disorders. Mar. Drugs 2018, 16, 250. [CrossRef]

228. Alam, T.; Khan, S.; Gaba, B.; Haider, M.F.; Baboota, S.; Ali, J. Nanocarriers as treatment modalities for hypertension. Drug Deliv. 2017, 24, 358-369. [CrossRef]

229. Seca, A.M.L.; Pinto, D.C.G.A. Overview on the antihypertensive and anti-obesity effects of secondary metabolites from seaweeds. Mar. Drugs 2018, 16, 237. [CrossRef] [PubMed]

230. Olasehinde, T.A.; Olaniran, A.O.; Okoh, A.I. Macroalgae as a valuable source of naturally occurring bioactive compounds for the treatment of Alzheimer's disease. Mar. Drugs 2019, 17, 609. [CrossRef] [PubMed]

231. Gouras, G.K.; Olsson, T.T.; Hansson, O. $\beta$-amyloid peptides and amyloid plaques in Alzheimer's disease. Neurotherapeutics 2015, 12, 3-11. [CrossRef]

232. Frozza, R.L.; Lourenco, M.V.; de Felice, F.G. Challenges for Alzheimer's disease therapy: Insights from novel mechanisms beyond memory defects. Front. Neurosci. 2018, 12, 1-13. [CrossRef]

233. Cai, H.; Wang, Y.; McCarthy, D.; Wen, H.; Borchelt, D.R.; Price, D.L.; Wong, P.C. BACE1 is the major $\beta$-secretase for generation of $A \beta$ peptides by neurons. Nat. Neurosci. 2001, 4, 233-234. [CrossRef]

234. Choi, B.W.; Lee, H.S.; Shin, H.C.; Lee, B.H. Multifunctional activity of polyphenolic compounds associated with a potential for Alzheimer's disease therapy from ecklonia cava. Phyther. Res. 2015, 29, 549-553. [CrossRef] [PubMed]

235. Choi, J.S.; Haulader, S.; Karki, S.; Jung, H.J.; Kim, H.R.; Jung, H.A. Acetyl- and butyryl-cholinesterase inhibitory activities of the edible brown alga Eisenia bicyclis. Arch. Pharm. Res. 2015, 38, 1477-1487. [CrossRef] [PubMed] 
236. Olasehinde, T.A.; Olaniran, A.O.; Okoh, A.I. Phenolic composition, antioxidant activity, anticholinesterase potential and modulatory effects of aqueous extracts of some seaweeds on $\beta$-amyloid aggregation and disaggregation. Pharm. Biol. 2019, 57, 460-469. [CrossRef] [PubMed]

237. Olasehinde, T.A.; Olaniran, A.O.; Okoh, A.I. Aqueous-ethanol extracts of some South African seaweeds inhibit beta-amyloid aggregation, cholinesterases, and beta-secretase activities in vitro. J. Food Biochem. 2019, 43, 1-10. [CrossRef]

238. Kim, J.J.; Kang, Y.J.; Shin, S.A.; Bak, D.H.; Lee, J.W.; Lee, K.B.; Yoo, Y.C.; Kim, D.K.; Lee, B.H.; Kim, D.W.; et al. Phlorofucofuroeckol improves glutamate- induced neurotoxicity through modulation of oxidative stress-mediated mitochondrial dysfunction in PC12 cells. PLoS ONE 2016, 11, e0163433. [CrossRef]

239. Yang, E.J.; Ahn, S.; Ryu, J.; Choi, M.S.; Choi, S.; Chong, Y.H.; Hyun, J.W.; Chang, M.J.; Kim, H.S. Phloroglucinol attenuates the cognitive deficits of the 5XFAD mouse model of Alzheimer's disease. PLoS ONE 2015, 10, e0135686. [CrossRef]

240. Wang, J.; Zheng, J.; Huang, C.; Zhao, J.; Lin, J.; Zhou, X.; Naman, C.B.; Wang, N.; Gerwick, W.H.; Wang, Q.; et al. Eckmaxol, a phlorotannin extracted from Ecklonia maxima, produces anti- $\beta$-amyloid oligomer neuroprotective effects possibly via directly acting on glycogen synthase kinase 3ß. ACS Chem. Neurosci. 2018, 9, 1349-1356. [CrossRef]

241. Lee, S.; Youn, K.; Kim, D.H.; Ahn, M.R.; Yoon, E.; Kim, O.Y.; Jun, M. Anti-neuroinflammatory property of phlorotannins from Ecklonia cava on A $\beta$ 25-35 -induced damage in PC12 cells. Mar. Drugs 2019, $17,7$. [CrossRef]

242. Um, M.Y.; Lim, D.W.; Son, H.J.; Cho, S.; Lee, C. Phlorotannin-rich fraction from Ishige foliacea brown seaweed prevents the scopolamine-induced memory impairment via regulation of ERK-CREB-BDNF pathway. J. Funct. Foods 2018, 40, 110-116. [CrossRef]

243. Lesné, S.; Ali, C.; Gabriel, C.; Croci, N.; MacKenzie, E.T.; Glabe, C.G.; Plotkine, M.; Marchand-Verrecchia, C.; Vivien, D.; Buisson, A. NMDA receptor activation inhibits $\alpha$-secretase and promotes neuronal amyloid- $\beta$ production. J. Neurosci. 2005, 25, 9367-9377. [CrossRef]

244. Figueira, I.; Garcia, G.; Pimpão, R.C.; Terrasso, A.P.; Costa, I.; Almeida, A.F.; Tavares, L.; Pais, T.F.; Pinto, P.; Ventura, M.R.; et al. Polyphenols journey through blood-brain barrier towards neuronal protection. Sci. Rep. 2017, 7, 1-16. [CrossRef] [PubMed]

245. Schram, F.R.; Ng, P.K.L. What is cancer? J. Crustac. Biol. 2012, 32, 665-672. [CrossRef]

246. Gutiérrez-Rodríguez, A.G.; Juárez-Portilla, C.; Olivares-Bañuelos, T.; Zepeda, R.C. Anticancer activity of seaweeds. Drug Discov. Today 2018, 23, 434-447. [CrossRef]

247. Matulja, D.; Wittine, K.; Malatesti, N.; Laclef, S.; Turks, M.; Markovic, M.K.; Ambrožić, G.; Marković, D. marine natural products with high anticancer activities. Curr. Med. Chem. 2020, 27, 1243-1307. [CrossRef] [PubMed]

248. Kim, J.; Lee, J.; Oh, J.H.; Chang, H.J.; Sohn, D.K.; Shin, A.; Kim, J. Associations among dietary seaweed intake, c-MYC rs6983267 polymorphism, and risk of colorectal cancer in a Korean population: A case-control study. Eur. J. Nutr. 2020, 59, 1963-1974. [CrossRef] [PubMed]

249. Mhadhebi, L.; Mhadhebi, A.; Robert, J.; Bouraoui, A. Antioxidant, anti-inflammatory and antiproliferative effects of aqueous extracts of three mediterranean brown seaweeds of the Genus Cystoseira. Iran. J. Pharm. Res. 2014, 13, 207-220. [CrossRef]

250. Corona, G.; Coman, M.M.; Spencer, J.P.E.; Rowland, I. Digested and fermented seaweed phlorotannins reduce DNA damage and inhibit growth of HT-29 colon cancer cells. Proc. Nutr. Soc. 2014, 73, 262519. [CrossRef]

251. Mwangi, H.M.; Njue, W.M.; Onani, M.O.; Thovhoghi, N.; Mabusela, W.T. Phlorotannins and a sterol isolated from a brown alga Ecklonia maxima, and their cytotoxic activity against selected cancer cell lines HeLa, H157 and MCF7. Interdiscip. J. Chem. 2017, 2,1-6. [CrossRef]

252. Namvar, F.; Baharara, J.; Mahdi, A.A. Antioxidant and anticancer activities of selected Persian Gulf algae. Indian J. Clin. Biochem. 2014, 29, 13-20. [CrossRef]

253. Lopes-Costa, E.; Abreu, M.; Gargiulo, D.; Rocha, E.; Ramos, A.A. Anticancer effects of seaweed compounds fucoxanthin and phloroglucinol, alone and in combination with 5-fluorouracil in colon cells. J. Toxicol. Environ. Heal. Part A Curr. Issues 2017, 80, 776-787. [CrossRef]

254. Arai, M.; Shin, D.; Kamiya, K.; Ishida, R.; Setiawan, A.; Kotoku, N.; Kobayashi, M. Marine spongean polybrominated diphenyl ethers, selective growth inhibitors against the cancer cells adapted to glucose starvation, inhibits mitochondrial complex II. J. Nat. Med. 2017, 71, 44-49. [CrossRef] [PubMed] 
255. Bernardini, G.; Minetti, M.; Polizzotto, G.; Biazzo, M.; Santucci, A. Pro-Apoptotic activity of French polynesian Padina pavonica extract on human osteosarcoma cells. Mar. Drugs 2018, 16, 504. [CrossRef] [PubMed]

256. Kosanić, M.; Ranković, B.; Stanojković, T. Brown macroalgae from the Adriatic Sea as a promising source of bioactive nutrients. J. Food Meas. Charact. 2019, 13, 330-338. [CrossRef]

257. Abdelhamid, A.; Lajili, S.; Elkaibi, M.A.; Ben Salem, Y.; Abdelhamid, A.; Muller, C.D.; Majdoub, H.; Kraiem, J.; Bouraoui, A. Optimized extraction, preliminary characterization and evaluation of the in vitro anticancer activity of phlorotannin-rich fraction from the brown seaweed, Cystoseira sedoides. J. Aquat. Food Prod. Technol. 2019, 28, 892-909. [CrossRef]

258. Abu-Khudir, R.; Ismail, G.A.; Diab, T. Antimicrobial, antioxidant, and anti-tumor activities of Sargassum linearifolium and Cystoseira crinita from Egyptian Mediterranean Coast. Nutr. Cancer 2020, 0,1-16. [CrossRef]

259. Premarathna, A.D.; Ranahewa, T.H.; Wijesekera, S.K.; Harishchandra, D.L.; Karunathilake, K.J.K.; Waduge, R.N.; Wijesundara, R.R.M.K.K.; Jayasooriya, A.P.; Wijewardana, V.; Rajapakse, R.P.V.J. Preliminary screening of the aqueous extracts of twenty-three different seaweed species in Sri Lanka with in-vitro and in-vivo assays. Heliyon 2020, 6, e03918. [CrossRef]

260. Ahn, J.H.; Yang, Y.I.; Lee, K.T.; Choi, J.H. Dieckol, isolated from the edible brown algae Ecklonia cava, induces apoptosis of ovarian cancer cells and inhibits tumor xenograft growth. J. Cancer Res. Clin. Oncol. 2015, 141, 255-268. [CrossRef]

261. Yang, Y.I.; Ahn, J.H.; Choi, Y.S.; Choi, J.H. Brown algae phlorotannins enhance the tumoricidal effect of cisplatin and ameliorate cisplatin nephrotoxicity. Gynecol. Oncol. 2015, 136, 355-364. [CrossRef]

262. Eo, H.J.; Kwon, T.H.; Park, G.H.; Song, H.M.; Lee, S.J.; Park, N.H.; Jeong, J.B. In vitro anticancer activity of phlorofucofuroeckol a via upregulation of activating transcription factor 3 against human colorectal cancer cells. Mar. Drugs 2016, 14, 69. [CrossRef]

263. Park, C.; Lee, H.; Hwangbo, H.; Ji, S.Y.; Kim, M.Y.; Kim, S.Y.; Hong, S.H.; Kim, G.Y.; Choi, Y.H. Ethanol extract of Hizikia fusiforme induces apoptosis in B16F10 mouse melanoma cells through ROS-dependent inhibition of the PI3K/Akt signaling pathway. Asian Pacific J. Cancer Prev. 2020, 21, 1275-1282. [CrossRef]

264. Lee, H.; Kang, C.; Jung, E.S.; Kim, J.S.; Kim, E. Antimetastatic activity of polyphenol-rich extract of Ecklonia cava through the inhibition of the Akt pathway in A549 human lung cancer cells. Food Chem. 2011, 127, 1229-1236. [CrossRef] [PubMed]

265. Kim, R.K.; Uddin, N.; Hyun, J.W.; Kim, C.; Suh, Y.; Lee, S.J. Novel anticancer activity of phloroglucinol against breast cancer stem-like cells. Toxicol. Appl. Pharmacol. 2015, 286, 143-150. [CrossRef]

266. Kim, R.K.; Suh, Y.; Yoo, K.C.; Cui, Y.H.; Hwang, E.; Kim, H.J.; Kang, J.S.; Kim, M.J.; Lee, Y.Y.; Lee, S.J. Phloroglucinol suppresses metastatic ability of breast cancer cells by inhibition of epithelial-mesenchymal cell transition. Cancer Sci. 2015, 106, 94-101. [CrossRef] [PubMed]

267. Qi, X.; Liu, G.; Qiu, L.; Lin, X.; Liu, M. Marine bromophenol bis(2,3-dibromo-4,5-dihydroxybenzyl) ether, represses angiogenesis in HUVEC cells and in zebrafish embryos via inhibiting the VEGF signal systems. Biomed. Pharmacother. 2015, 75, 58-66. [CrossRef] [PubMed]

268. Sadeeshkumar, V.; Duraikannu, A.; Ravichandran, S.; Kodisundaram, P.; Fredrick, W.S.; Gobalakrishnan, R. Modulatory efficacy of dieckol on xenobiotic-metabolizing enzymes, cell proliferation, apoptosis, invasion and angiogenesis during NDEA-induced rat hepatocarcinogenesis. Mol. Cell. Biochem. 2017, 433, 195-204. [CrossRef] [PubMed]

269. Li, Y.X.; Li, Y.; Je, J.Y.; Kim, S.K. Dieckol as a novel anti-proliferative and anti-angiogenic agent and computational anti-angiogenic activity evaluation. Environ. Toxicol. Pharmacol. 2015, 39, 259-270. [CrossRef]

270. Zhen, A.X.; Hyun, Y.J.; Piao, M.J.; Devage, P.; Madushan, S. Eckol inhibits particulate matter 2.5-induced skin damage via MAPK signaling pathway. Mar. Drugs 2019, 17, 444. [CrossRef]

271. Zhang, M.Y.; Guo, J.; Hu, X.M.; Zhao, S.Q.; Li, S.L.; Wang, J. An in vivo anti-tumor effect of eckol from marine brown algae by improving the immune response. Food Funct. 2019, 10, 4361-4371. [CrossRef] [PubMed]

272. Ford, J.M.; Kastan, M.B. DNA Damage response pathways and fcancer. In Abeloff's Clinical Oncology: Fifth Edition; Saunders: Philadelphia, PA, USA, 2013; pp. 142-153.e4, ISBN 9780323222112.

273. Singh, A.K.; Cabral, C.; Kumar, R.; Ganguly, R.; Rana, H.K.; Gupta, A.; Lauro, M.R.; Carbone, C.; Reis, F.; Pandey, A.K. Beneficial effects of dietary polyphenols on gut microbiota and strategies to improve delivery efficiency. Nutrients 2019, 11, 2216. [CrossRef] 
274. Guo, B.; Liu, B.; Wei, H.; Cheng, K.W.; Chen, F. Extract of the microalga Nitzschia laevis prevents high-fat-diet-induced obesity in mice by modulating the composition of gut microbiota. Mol. Nutr. Food Res. 2019, 63, 1-14. [CrossRef]

275. Newman, D.J.; Cragg, G.M. Natural products as sources of new drugs from 1981 to 2014. J. Nat. Prod. 2016, 79, 629-661. [CrossRef] [PubMed]

276. Rajauria, G.; Jaiswal, A.K.; Abu-Gannam, N.; Gupta, S. Antimicrobial, antioxidant and free radical-scavenging capacity of brown seaweed Himanthalia elongata from western coast of Ireland. J. Food Biochem. 2013, 37, 322-335. [CrossRef]

277. Besednova, N.N.; Zvyagintseva, T.N.; Kuznetsova, T.A.; Makarenkova, I.D.; Smolina, T.P.; Fedyanina, L.N.; Kryzhanovsky, S.P.; Zaporozhets, T.S. Marine algae metabolites as promising therapeutics for the prevention and treatment of HIV/AIDS. Metabolites 2019, 9, 87. [CrossRef] [PubMed]

278. Ahn, M.-J.; Yoon, K.-D.; Kim, C.Y.; Kim, J.H.; Shin, C.-G.; Kim, J.M. Inhibitory activity on HIV-1 reverse transcriptase and integrase of a carmalol derivative from a brown alga, Ishige okamurae. Phyther. Res. 2006, 20, 711-713. [CrossRef] [PubMed]

279. Artan, M.; Li, Y.; Karadeniz, F.; Lee, S.H.; Kim, M.M.; Kim, S.K. Anti-HIV-1 activity of phloroglucinol derivative, 6,6'-bieckol, from Ecklonia cava. Bioorganic Med. Chem. 2008, 16, 7921-7926. [CrossRef]

280. Karadeniz, F.; Kang, K.H.; Park, J.W.; Park, S.J.; Kim, S.K. Anti-HIV-1 activity of phlorotannin derivative 8,4"'-dieckol from Korean brown alga Ecklonia cava. Biosci. Biotechnol. Biochem. 2014, 78, 1151-1158. [CrossRef]

(C) 2020 by the authors. Licensee MDPI, Basel, Switzerland. This article is an open access article distributed under the terms and conditions of the Creative Commons Attribution (CC BY) license (http://creativecommons.org/licenses/by/4.0/). 